NBS MONOGRAPH 84

\title{
Standard Cells
}

Their Construction, Maintenance,

And Characteristics

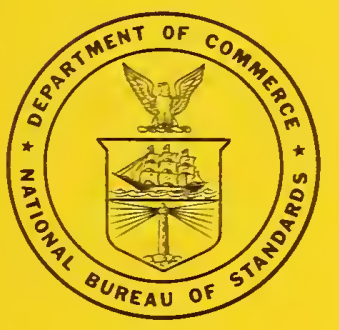

Lhovid. BâY A. R. S.

U.S. DEPARTMENT OF COMMERCE

NATIONAL BUREAU OF STANDARDS 


\section{THE NATIONAL BUREAU OF STANDARDS}

The National Bureau of Standards is a principal focal point in the Federal Government for assuring maximum application of the physical and engineering sciences to the advancement of technology in industry and commerce. Its responsibilities include development and maintenance of the national standards of measurement, and the provisions of means for making measurements consistent with those standards; determination of physical constants and properties of materials: development of methorls for testing materials. mechanisms, and structures, and making such tests as may be necessary. particularly for government agencies; cooperation in the establishment of standard practices for incorporation in codes and specifications; advisory service to government agencies on scientific and technical problems; invention and development of devices to serve special needs of the Government: assistance to industry; business, and consumers in the development and acceptance of commercial standards and simplified trade practice recommendations; administration of programs in cooperation with Lnited States business groups and standards organizations for the development of international standards of practice: and maintenance of a clearinghouse for the collection and dissemination of scientific, technical, and engineering information. The scope of the Bureau"s activities is suggested in the following listing of its four Institutes and their organizational units.

Institute for Basic Standards. Electricity. Metrology. Heat. Radiation Plysics. Mechanics. Applied Mathematics. Atomic Physics. Physical Chemistry. Laboratory Astrophysics.* Radio Standards Laboratory: Radio Standards Physics; Radio Standards Engineering.** Office of Standard Reference Data.

Institute for Materials Research. Analytical Chemistry. Polymers. Metallurgy. Inorganic Materials. Reactor Rarliations. Cryogenics.** Office of Standard Reference Materials.

Central Radio Propagation Laboratory.** Ionosphere Research and Propagation. Troposphere and Space Telecommunications. Radio Systems. Upper Atmosphere and Space Physics. Institute for Applied Technology. Textiles and Apparel Technology Center. Building Research. Industrial Equipment. Information Technology. Performance Test Development. Instrumentation. Transport Systems. Office of Technical Services. Office of Weiglits and Measures. Office of Engineering Standards. Office of Industrial Services.

*NBS Group, Joint Institute for Laboratory Astrophysics at the University of Colorado.

** Located at Boulder, Colorado. 
UNITED STATES DEPARTMENT OF COMMERCE - Luther H. Hodges, Secretary NATIONAL BUREAU OF STANDARDS - A. V. Astin, Director

\title{
Standard Cells
}

\section{Their Construction, Maintenance, and Characteristics}

\author{
Walter J. Hamer
}

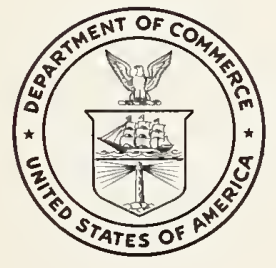

National Bureau of Standards Monograph 84 Issued January 15, 1965 
Library of Congress Catalog Card Number: 64-60065 


\section{Foreword}

Accurate measurement of electromotive force is important in many areas of science and technology. Physical standards for such measurement are provided by standard cells, which are long-lived electrochemical systems of highly stable electromotive force.

This publication gives the origin and derivation of the unit of electromotive force and outlines the procedures by which the National Bureau of Standards maintains and disseminates this unit by means of standard cells. Information is also given on the construction, maintenance, and characteristics of standard cells as well as a history of their development. Emphasis is placed on the precision and accuracy of electromotive force measurements; the stability of standard cells, especially those of the National Reference Group; and efforts made to construct standard cells of high quality.

A. V. Astin, Director 
Library of Congress Catalog Card Number: 64-60065 


\section{Foreword}

Accurate measurement of electromotive force is important in many areas of science and technology. Physical standards for such measurement are provided by standard cells, which are long-lived electrochemical systems of highly stable electromotive force.

This publication gives the origin and derivation of the unit of electromotive force and outlines the procedures by which the National Bureau of Standards maintains and disseminates this unit by means of standard cells. Information is also given on the construction, maintenance, and characteristics of standard cells as well as a history of their development. Emphasis is placed on the precision and accuracy of electromotive force measurements; the stability of standard cells, especially those of the National Reference Group; and efforts made to construct standard cells of high quality.

A. V. Astin, Director 


\section{Contents}

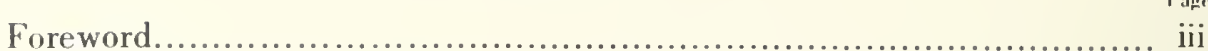

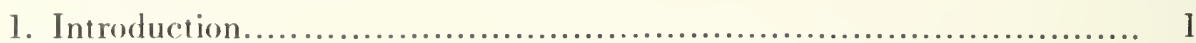

2. The unit of electromotive force..................................... 1

2.1. Realization.................................................. ]

2.2. History ......................................................... 4

2.3. Maintenance.................................................. 5

2.4. Dissemination................................................. 8

2.5. International comparisons.................................... 10

3. Early standard cells.................................................... 11

4. The Clark cell......................................................... 13

5. The Weston (or cadmium sulfate) cell.............................. 15

5.1. General.................................................... 15

5.2. Preparation and properties of materials....................... 16

5.3. Containers for standard cells................................ 19

5.4. Assembly and mounting of standard cells..................... 20

5.5. Electromotive forces of newly made cells...................... 21

6. Effect of variations in components on the electromotive force of standard cells......................................................... 22

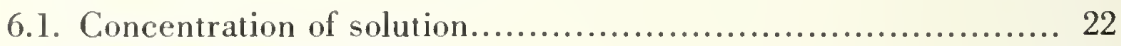

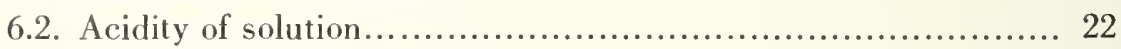

6.3. Composition of amalgam..................................... 23

6.4. Crystal phases of cadmium sulfate............................. 23

7. Characteristics of standard cells.................................. 23

7.1. Emf-temperature coefficient ............................. 23

7.2. Emf-temperature hysteresis................................ 26

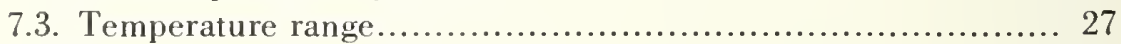

7.4. Emf-pressure coefficient...................................... 27

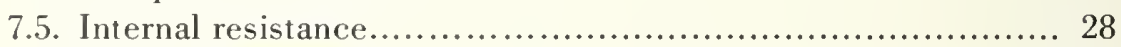

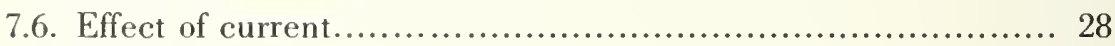

7.7. Effect of light............................................... 30

7.8. Effect of shock............................................. 30

7.9. Effect of vibration............................................... 30

8. Life of standard cells.............................................. 30

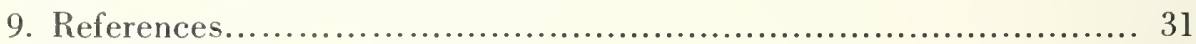

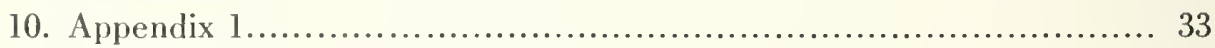

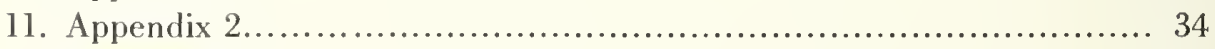

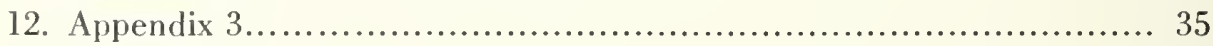

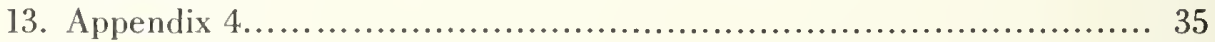

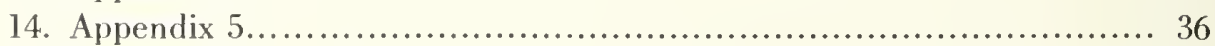

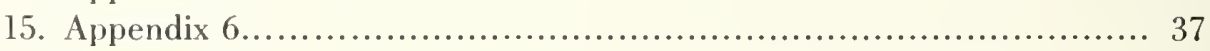

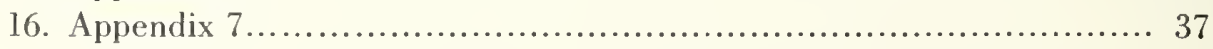




\title{
Their Construction, Maintenance, and Characteristics
}

\author{
Walter J. Hamer
}

\begin{abstract}
This Monograph contains information on the construction, maintenance, and characteristics of standard cells. The effects of temperature, pressure, electric current, light, shock, and vibration on standard cells are discussed. A history of the realization and maintenance of the unit of electromotive force is also included. A record of international comparisons of the unit of electromotive force is presented as well as information on the constancy of the National Reference Group of Standard Cells.
\end{abstract}

\section{Introduction}

Standard cells are physical representations of the unit of electromotive force (emf), serve in the maintenance of the unit, and are used as standards with which the emf of other cells and systems and $I R$ drops are compared. Together with standards of resistance $(R)$ they are also used in the measurement of current, $I$. When measurements of electric power, $P$, are made in terms of standards for emf $(E)$ and resistance, the expression for power, $P=E^{2} / R$, shows the necessity of knowing $E$ accurately, since a small error in the standard for $E$ would produce a percentage error twice as great in the value for the power, $P$.

Standard cells are electrochemical systems composed of two dissimilar electrodes immersed in an electrolytic solution. They are not intended to supply electric current and, therefore, are of dif- ferent design from those electrochemical systems which are intended for such purpose. Owing to their special use, standard cells are required to meet certain performance criteria and, for precise measurements, to have certain inherent characteristics. They must be reasonably reproducible, exhibit good permanency, possess low emf-temperature coefficients, have a low or moderately low internal resistance, be relatively insensitive to current drains of low magnitude, and, if possible, have an emf of convenient magnitude. Since a standard cell is a physical representation of a unit it is obvious why permanency is of prime importance in a standard cell. The precision with which the emf of standard cells is measured, accordingly, exceeds that normally required for other types of galvanic cells.

\section{The Unit of Electromotive Force}

\subsection{Realization}

The practical unit of emf, the volt, is not an arbitrary one but like the other electrical units is derived from the basic mechanical units of length, mass, and time using the principles of electromagnetism with the value of the magnetic constant (the so-called permeability of free space) taken as $4 \pi / 10^{7}$ in the rationalized mksa (meter-kilogramsecond-ampere) system of units. ${ }^{1}$ It has been customary, following the first use of the term by Gauss $[9],{ }^{2}$ to refer to electrical units based on the basic units of length, mass, and time as absolute electrical units. ${ }^{3}$ The transition from arbitrary to absolute units began with the work of Gauss [9] in 1833 and of Weber [2] in 1851, who showed that

\footnotetext{
${ }_{1 T}$ This is the Giorgi system [1], which is a part of the Système International d'Unites (SI), adopted in a resolution, ilth General Conference on Weights and Measures, Paris, Octuber 1960. Other systems for the basic units of length, mass, and time have been used. These include the millimeter-milligram-second system of Weber [2], the meter-gram-second system recommended by the first committee of the British Association for the Advancement of Science appointed to consider electrical units [3], the quadrant-(eleventh-gram)-second or O.E.S, system of Maxwell [4], the foot-grain. second system used in England for a time [5], and the cgs (centimeter-gram-second system [6] (see Appendix Heaviside also proposed a rationalized system wherein the cgs unit of emf was increased by a factor $\sqrt{4 \pi}$ (unit of resistance increased by a factor $4 \pi$ and the unit of current decreased by the factor $\sqrt{4 \pi}$ [7]). In all of these, the Giorgi system excepted, the magnetic constant (the permeability of free space) is taken as unity. Regardless of which system is chosen the practical system remains unaffected. Additional information on electrical units is given in reference [8].

2 Figures in brackets indicate the literature references on page 31.

"It is unfortunate that the name "absolute" has persisted. It is sometimes wrongly interpreted to imply that there are no errors involved in the measurements or that perfection has been attained.
}

it was possible to measure electrical quantities in terms of mechanical units. Weber pointed out the desirability of making the electrical units consistent with those used in other branches of science and engineering.

The electrical units determined in the cgs electromagnetic (em) system are of inconvenient size for practical use. For example, Sir William Thomson (Lord Kelvin) [10] in 1851 showed that the emf of a Daniell cell was about $1 \times 10^{8}$ cgs em units. Even so, a Committee of the British Association for the Advancement of Science in 1873 [6] recommended the cgs em system for use both in basic science and practical engineering. However, the practitioners, although they agreed with the desirability of relating electrical units to mechanical ones, objected to the use of the cgs em system of units in practice both because of the magnitudes involved and because they had been using such terms as ohms and volts for their units. Their views prevailed and in 1881 the International Congress of Electricians [11] meeting in Paris adopted the cgs em system of units as the fundamental system and ihe voltohm-ampere system for practical use, with the practical units being made larger or smaller than the corresponding cgs em units by an appropriate power of 10 . 
The factors chosen for emf, resistance, and current were:

$$
1 \text { volt (practical unit) }=10^{8} \mathrm{cgs} \text { electromagnetic }
$$
units of emf

1 ohm (practical unit) $=10^{9} \mathrm{cgs}$ electromagnetic
units of resistance

1 ampere (practical unit) $=10^{-1} \mathrm{cgs}$ electromagnetic unit of current.

The factor $10^{8}$ was chosen for emf since then the emf of a Daniell cell, widely used at that time as a rough standard of emf, became approximately 1 volt. The factor $10^{9}$ was chosen for resistance, for in this way the value of the Siemens mercury column, already used as a resistance standard, especially on the European continent, became approximately 1 ohm (actually about 0.94 ohm). The factor for the ampere was then fixed as $10^{-1}$ by the requirement of Ohm's law.

The unit of emf, although a most important unit, is obtained from the ohm and the ampere. To date, no direct absolute measurement of emf in the em system of units has been found feasible. Instead its value is established experimentally in em units through Ohm's law and the measurement of the fall of potential produced in a resistance by a current, each of these being capable of determination in absolute measure. ${ }^{4}$

The ohm in absolute measure is usually obtained in terms of length and time by means of inductance and frequency. In the Wenner [15] method, a mutual inductor of known dimensions, and thus of calculable inductance, is placed in a suitable circuit containing the resistor the value of which is to be determined, a battery, a galvanometer, and two rotary reversing switches. The primary of the mutual inductor is placed in series with the battery and resistor, and with one rotary reversing switch so arranged as to reverse the comnections to the primary. The secondary of the mutual inductor is connected to the potential terminals of the resistor through a galvanometer and a rotary reversing switch for reversing the connections to the secondary terminals. The galvanometer detects the balance between the induced emf in the secondary and the $I_{r} R$ drop across the resistor. When balance is obtained, i.e., when the galvanometer shows no deflection, $I_{r} R=4 n I_{p} M$ where $I_{r}$ is the current in the resistor, $I_{p}$ the current in the primary, $M$ is the computable mutual inductance, and $n$ is

\footnotetext{
"The unit of emf may also be determined in cgs electrostatic (es) units, with the electric constant (the so-called permitivity of free space) taken as unity, using absolute electrometers. The accuracy of the methods, however, is much lower than the em approach, the order of magnitude being 1 part in 10,000 . The unit of emf in es units is, therefore, arrived at indirectly by converting em values to es values using the ex. perimental factor, $(2.997925 \pm 0.000003) \times 10^{10} \mathrm{~cm} \mathrm{sec}^{-1}$, tlse speed of propagation of an electrical disturbance (within experimental error, the speed of light in free space) an electrical disturbance (within experimental error, the speed of light in free space),
As an example. Sir William Thomson (Lord Kelvin) [12] found the emf of a Daniell As an example. Sir William Thomson (Lord Kelvin) [12] found the emf of a Daniell
cell to be 0.00374 cgs es unit from the attraction between two parallel disks connected to the oppositc poles of a Daniell cell. This value of Thomson is equivalent to $1.121 \times 10^{4} \mathrm{cgs}$ em units or 1.121 volts.

An atomic standard for the volt, although most desirable, has not been forthcoming to date. The Stark effect has bren proposed [13] but can be used only to measure relative voltage and is of insufficient accuracy, with the limiting factor residing in the measurement of the electric dipole noment [14].
}

the frequency of commutation in cycles per second ( $2 n=$ a number of reversals per second of the rotary reversing switch in the secondary). The circuit is so arranged that during that portion of the cycle when the primary of the mutual inductor is in series with the resistor, $I_{r}=I_{p}$; thus

$$
R=4 n M \text {. }
$$

Since $M$ is calculated from dimensions with reference to length standards and from the permeability of the medium, and $n$ is measured indirectly in terms of the unit of time, $R$ is given in terms of the basic units of length and time and of the permeability of the space surrounding the windings of the inductor. The overall precision (repeatability) of the method is \pm 5 parts per million (ppm). For more details, reference [16] should be consulted. The ohm in absolute measure may also be obtained with similar accuracy using a self inductor [17], or with lesser accuracy by measuring the relative rotation of a coil and a magnet or the motion of a coil in the earth's magnetic field. Although the latter methods are now obsolete they are mentioned here because of their historical importance in the evolution of the electrical units.

The ohm in absolute measure may also be obtained using a computable capacitor [18]. In this method the evaluation of resistance is based on a nominally 1-pf capacitor whose value in es units may be calculated with high accuracy from its dimensions and thence in em units using the speed of light. This capacitor is then used to calibrate $0.01-\mu$ f capacitors, the admittances of which are then compared with that of a $10^{4}$-ohm shielded $\mathrm{a} \cdot \mathrm{c}$ resistor using a special bridge network. A conventional d-c step-down is then used to provide "absolute" calibration of $d-c$ resistors of lower magnitude, specifically 1 ohm. For more details, reference [18] should be consulted. The overall precision (repeatability) of the method is about \pm 2 ppm. Operationally, this method is less involved than the inductance methods and may be used on an annual basis to check on the constancy. of the resistance standard.

The ampere in absolute measure is obtained in terms of length, mass, and time with a current balance [19]. In the current balance the electro. dynamic force of attraction or repulsion, in the $x$ (vertical) direction, between two coils (one movable and one stationary) through which a current is flowing is balanced against the force of gravity, $m g$, acting on a known mass, $m$, at a location where $g$ is the acceleration due to gravity. From this force and the measured dimensions of the coils (from which the rate of increase, $d M / d x$, of the mutual inductance between the stationary and movable coils may be calculated) together with the permeability of space in which the coils act, the current is expressed in terms of units of length, mass, and time, where time enters into the calculations through the acceleration of gravity. The overall precision (repeatability) of this method is about \pm 6 ppm. The ampere may also be obtained 
with an uncertainty of about \pm 8 ppm by an electrodynamometer in which a torque rather than a force is measured [20]. The combined precision (repeatability) in determining the ampere in absolute measure is about $\pm 5 \mathrm{ppm}$. For more details references [19] and [20] should be consulted. The ampere in absolute measure may be obtained qualitatively by using a tangent or sine galvanometer where the current is measured in terms of the deflection of a magnetic needle, the radius of the galvanometer coil, and the horizontal component of intensity of the earth's magnetic field. Although these measurements are now obsolete they are of historical importance; see later. The current balance methods are involved and accordingly are used only about once every five or ten years. However, in recent years, following the discovery of nuclear resonance, a new method, although not an "absolute" one, has been developed to check on the constancy of the ampere as maintained at NBS in terms of the physical standards of resistance and emf. This method [21] is based on the determination of the gyromagnetic ratio of the proton in which the precession frequency of the proton is measured in a magnetic field known in terms of the "absolute" ampere and the constant of an accurately made solenoid. By this method drifts in the national ampere of about $\pm 1 \mathrm{ppm}$ over a period of years can now be detected; also the method may be used annually to check the constancy of the ratio of the national standards of emf and resistance (see sec. 2.3). For more details on this method, reference [21] should be consulted.

The volt in absolute measure is obtained at the same time a measurement of the absolute ampere is made. The usual procedure is to connect in series with the coils of the current balance a resistor having a value, $R$, previously obtained in absolute measure. The voltage drop, $I R$, in this resistor is opposed to the emf, $E$, of a standard cell. When the current, $I$, is held at such a value that $I R$ balances $E$ and at the same time the mass, $m$, of the weight has been adjusted to balance the electrodynamic force, the relation

$$
E=R[m g /(d M / d x)]^{1 / 2}=R I
$$

follows and gives the emf of the standard cell in absolute measure. The experimental uncertainty in the balance between the emf of the standard cell and the $I R$ drop in the standard resistor is less than 0.1 microvolt. Considering the experimental precisions of the absolute determinations of $R$ and $I$, the precision in the determination of the volt in absolute measure is about $\pm 7 \mathrm{ppm}$ ( $\mathrm{rms}$ ).

The volt, as now maintained in the United States, may exceed the absolute volt by as much as $18 \mathrm{ppm}$ or as little as $2 \mathrm{ppm}$. Driscoll and Cutkosky [19] in 1958, as a result of measurements with a current balance and a Pellat electrodynamometer reported that

$$
1 \text { NBS ampere }=1.000010 \pm 0.000005 \text { absolute }
$$

In these measurements they used a value for gravity $17 \mathrm{ppm}$ lower than that derived from Potsdam. Recent studies have shown that $-13 \mathrm{ppm}$ is a better correction of the value derived from Potsdam. Using this correction,

1 NBS ampere $=1.000012 \pm 0.000005$ absolute
amperes

Cutkosky [18] in 1961, as a result of studies with precision computable capacitors, found that ${ }^{5}$

1 NBS ohm $=1.0000006 \pm 0.0000021$ absolute ohms.

He also, by recalculating the results of Thomas, Peterson, Cooter, and Kotter [16] obtained with a Wenner mutual inductor, gave

\section{NBS ohm $=0.999997$ absolute ohm.}

(J. L. Thomas has estimated the uncertainty in this value to be \pm 0.000005 ). From these relations for the ohm and using the second relation for the ampere,

\section{NBS volt $=1.000013 \pm 0.000005$ absolute volts,}

or

1 NBS volt $=1.000009 \pm 0.000007$ absolute volts.

The NBS volt, as now maintained by standard cells at the National Bureau of Standards, is the one disseminated. When additional data on the above relations are obtained in the United States and other countries, the International Committee of the Bureau International des Poids et Mesures, Sèvres, France, which, by international treaty, has authority to coordinate the standards of measurements in the field of electricity as well as of length and mass, may recommend adjustment in the electrical units. Until then, the units as maintained and disseminated by NBS serve to place laboratories in the United States on the same standard basis, accepted by all nations cooperating in the Treaty of the Meter.

The emf of any or all standard cells could be determined in like fashion. Obviously, such a procedure would be cumbersome and time consuming and if required would be unfortunate, indeed. Absolute measurements are involved, require painstaking work and, therefore, are unsuitable for frequent or routine measurements of emf. To circumvent the necessity for frequent absolute measurements, standard cells ${ }^{6}$ are constructed, their emfs are determined in relation to current and resistance in absolute measure, and these cells are then used to maintain the volt; these

\footnotetext{
-This value differs by 1.7 ppm from that $\left(1.000002_{3}\right)$ published by Cutkosky [18]. He has since uncovered an error of this magnitude in the published value.

- Standard resistors. usually hermetically sealed cuils of annealed manganin wire [22], are used similarly to maintain the unit of resistance. Owing to the transitory nature of an electric current no physical standards for an ampere have been, to date possible. Instead the standard ampere is given by the ratio of the values for the standard cell and the standard resistor.
} 
cells are also used to assign emfs to other cells that may be constructed. In other words, the results of absolute measurements are preserved in a physical object, the standard cell. ${ }^{6}$ The validity and realization of this approach depends on the possibility of constructing standard cells, the emfs of which are independent (or nearly so) of time; otherwise, the unit of emf would be lost or drift in value in the interim and a repetition of absolute measurements would be imperative at frequent intervals. It is obvious that this matter was and is of critical importance. Over the years extensive work has been conducted to find that electrochemical system which would exhibit constant emfs for long periods of time, say decades. Fortunately, such an electrochemical system (see below under the Weston Cell) has been found. The manner in which the unit of emf is maintained by a group of standard cells is discussed below under maintenance.

\subsection{History}

In 1893 the International Electrical Congress meeting in Chicago chose the Clark cell, a cell devised by Latimer Clark in 1872 [23], as the standard of emf to which they assigned a value of 1.434 international volts at $15{ }^{\circ} \mathrm{C}$ in terms of the then accepted standards for the ohm and the ampere. The Clark cell and this value for it were legalized as the standard of emf in the United States by an act of Congress, July 12, 1894 (see Appendix 1). The value, 1.434 international volts at $15^{\circ} \mathrm{C}$, followed from the determinations made by Rayleigh and Sidgwick [24], Carhart [25], Kahle [26], and Glazebrook and Skinner [27] who used current balances or silver coulometers (the electrochemical equivalent of silver having been determined by absolute methods) to determine current and B.A. coils $^{7}$ or Siemens mercury columns (or British

\footnotetext{
7.A. coil refers to British Association for Advancement of Science coil of silverplatinum alloy (66.6 percent Ag, 33.4 percent $\mathrm{Pt}$ ); the B.A. ohm $=0.9866$ international ohm. The Siemens ohm standard consisted of a column of chemically pure mercury $\mathrm{ohm}$. The Siemens ohm standard consisted of a column of chemically pure mercury
1 meter long and 1 square millimeter in cross-section at a temperature of $0{ }^{\circ} \mathrm{C}$. Carhart and Kahle used Siemens units and then converted their results to British legal ohms. The British legal ohm was represented by B.A. coils, the resistances of which were related to the 1884 "legal ohm," the resistance at $0{ }^{\circ} \mathrm{C}$ of a column of mercury 106 centimeters long and one square millimeter in cross-section; one British legal $\mathrm{ohm}=0.9976$ international $\mathrm{ohm}$; one British legal ohm $=1.06$ Siemens ohm.
}

legal ohms) ${ }^{7}$ (known in cgs em units) as standards of resistance. Their results are summarized in table 1. In each case, the results were converted to a common international basis (see Appendix l for the defined international units). The emftemperature formula of Lord Rayleigh [24, 29] which was then available was used to convert all the values to a temperature of $15^{\circ} \mathrm{C}$. The values were referred to as "iniernational" because internationa' agreement had been attained; it was also realized at the time that additional work would be needed to place the values on a basis truly representative of the theoretical cgs em units.

In the years immediately following 1893 most countries adopted 1.434 $\mathrm{V}$ for the emf of the Clark cell at $15{ }^{\circ} \mathrm{C}$. Later work showed that cells made with specially purified mercurous sulfate (see below for a description of the Clark cell) had an emf $0.0003 \mathrm{~V}$ lower than $1.434 \mathrm{~V}$ obtained for cells made prior to the meeting of the Chicago International Electrical Congress. Germany, however, in 1898 recommended and adopted $1.4328 \mathrm{~V}$ at $15^{\circ} \mathrm{C}$ for the Clark cell based on the German values for the ohm and ampere. Although the German value was not universally accepted, it was a more nearly correct value as later experiments showed. Also during the years 1893 to 1905 the standard cell devised by Edward Weston [30] was found to have many advantages over the Clark cell and at an informal international conference called by the Physikalisch-Technische Reichsanstalt at Charlottenburg in October 1905, the Weston Normal Cell (see later for description) was first proposed as a standard to be used for maintaining the volt and was officially adopted in 1908 at the London International Conference on Electrical Units and Standards [31].

This London Conference went further and adopted provisionally $1.0184 \mathrm{~V}$ as the emf of the Weston Normal Cell at $20^{\circ} \mathrm{C}$ and recommended for the emf-temperature coefficient of the Weston Normal Cell the formula based on the measurements of Wolff [32]. The London Conference still felt, however, that further work was needed and recommended that additional experiments be made.

TABLE 1. Absolute measurements of the electromotive force of the Clark cell

\begin{tabular}{|c|c|c|c|c|c|c|}
\hline \multirow[b]{2}{*}{ Experimenters } & \multirow[b]{2}{*}{ Temperature } & \multirow[b]{2}{*}{ Resistance unit } & \multirow[b]{2}{*}{ Current method } & \multirow{2}{*}{$\begin{array}{c}\text { Experi- } \\
\text { menters' } \\
\text { value (prior } \\
\text { to reduction) }\end{array}$} & \multicolumn{2}{|c|}{ International values } \\
\hline & & & & & $\begin{array}{l}\text { at observed } \\
\text { temperature }\end{array}$ & at $15^{\circ} \mathrm{C}$ \\
\hline $\begin{array}{l}\text { Rayleigh and Sidgwick } \\
\text { Carhart } \\
\text { Kahle } \\
\text { Glazebrook and Skinner }\end{array}$ & $\begin{array}{l}\text { Celsius } \\
15.0^{\circ} \\
18.0^{\circ} \\
15.0^{\circ} \\
15.0^{\circ}\end{array}$ & $\begin{array}{l}\text { B.A. ohm } \\
\text { Siemens ohm } \\
\text { Siemens ohm } \\
\text { B.A. ohm }\end{array}$ & $\begin{array}{l}\text { current balance } \\
\text { silver coulometer }{ }^{d} \\
\text { silver coulometer }{ }^{d} \\
\text { silver coulometer }{ }^{d}\end{array}$ & $\begin{array}{l}\quad \text { volts } \\
1.4539 \mathrm{e} \\
1.434 \mathrm{f.g} \\
1.4377 \mathrm{f.g} \\
1.4537 \mathrm{e}\end{array}$ & $\begin{array}{l}\text { volts } \\
1.4344 \\
1.431 \\
1.4342 \\
1.4342\end{array}$ & $\begin{array}{l}\text { volts } \\
1.4344 \\
1.434 \\
1.4342 \\
1.4342\end{array}$ \\
\hline & & & & & $\begin{array}{l}\text { average } \\
\text { rounded } \\
\text { value }\end{array}$ & $\begin{array}{l}1.4342 \\
1.434\end{array}$ \\
\hline
\end{tabular}

${ }^{\circ}$ - Carhart [28] later stated that the value $1.434 \mathrm{~V}$ was for a mean of two experiments, one at $18{ }^{\circ} \mathrm{C}$ and one at $17^{\circ} \mathrm{C}$; a correction for this does not alter the rounded value of $1.434 \mathrm{~V}$ given above for the absolute emf of the Clark cell.

- 1 B.A. ohm $=0.9866$ international ohm.

d- $1.118 \mathrm{mg}$ silver deposited per second per ampere (international value of electrochemical equivalent of silver).

- $1.18 \mathrm{mg}$

I-British legal volt.

- I British legal ohm $=0.9976$ international ohm. 
Accordingly, scientists from England, France, and Germany met with United States scientists at the National Bureau of Standards in 1910, and as a result of their experiments with a large number of Weston normal cells and silver-coulometer determinations adopted $1.0183 \mathrm{~V}$ as the emf of the Weston Normal Cell at $20^{\circ} \mathrm{C}$. Values derived from this were later assumed to be significant to the fifth, sixth, or seventh decimal as a basis of measurement $[33,34]$. This value $(1.0183 \mathrm{~V})$ was. still characterized in "international" units since the basis on which the new measurements (1910) were made was the same as it was in 1893; the precision of the measurements was higher, however.

Values assigned to the reference groups of each cooperating nation served as the fundamental basis of all emf measurements from 1911 to 1948 . By 1948, after interruptions caused by the two World Wars and after improvements in techniques, an accurate determination of the electrical quantities in cgs em units was achieved, and on January 1 , 1948, changes from international to absolute units were officially made internationally. ${ }^{8}$ The legal status of these new units in the United States is exactly the same as that of the older ones because the law of 1894 (see Appendix 1) mentions both sets

8 Although "international" and "absolute" are frequently used in referring to the units it is now best to consider these terms of historical interest only. There is only one during the period during which efforts were being made to achieve the theoretical unit It is deemed advisable to speak, therefore, of only one kind of volt; when the term "volt" is used, "absolute volt" is implied, i.e., the volt has a direct relation to the theoretical unit. of units on an equivalent basis. However, in order to remove the ambiguities of the old act, new legislation was passed by the Congress in 1950 (see Appendix 2). The changes [35] for the United States were:

1 international volt $(\mathrm{US})=1.000330$ absolute volts

1 international ohm (US) $=1.000495$ absolute ohms

1 international ampere (US) $=0.999835$ absolute ampere

1 international coulomb (US) $=0.999835$ absolute coulomb

1 international henry (US) $=1.000495$ absolute henries

1 international farad (US) $=0.999505$ absolute farad

1 international watt (US) $=1.000165$ absolute watts

1 international joule (US) $=1.000165$ absolute joules

The conversion factors in other countries were nearly the same as these. The emf of the Weston Normal Cell at $20{ }^{\circ} \mathrm{C}$ on the new basis then became $1.01864 \mathrm{~V}$. This value is now of historical interest only.

The relation of the fundamental units to the measurement of power and energy in both the new and former systems of units is shown diagrammatically in figure 1. The left half represents the fundamental units and standards maintained by the National Bureau of Standards, the right half the units and standards used by the public.

\subsection{Maintenance}

The unit of electromotive force in the United States was originally maintained (1897-1906) by seven Clark cells, the mean emf of which was assigned a value of $1.4337 \mathrm{~V}$ (this value was $0.0003 \mathrm{~V}$ lower than the value recommended in 1893 by the

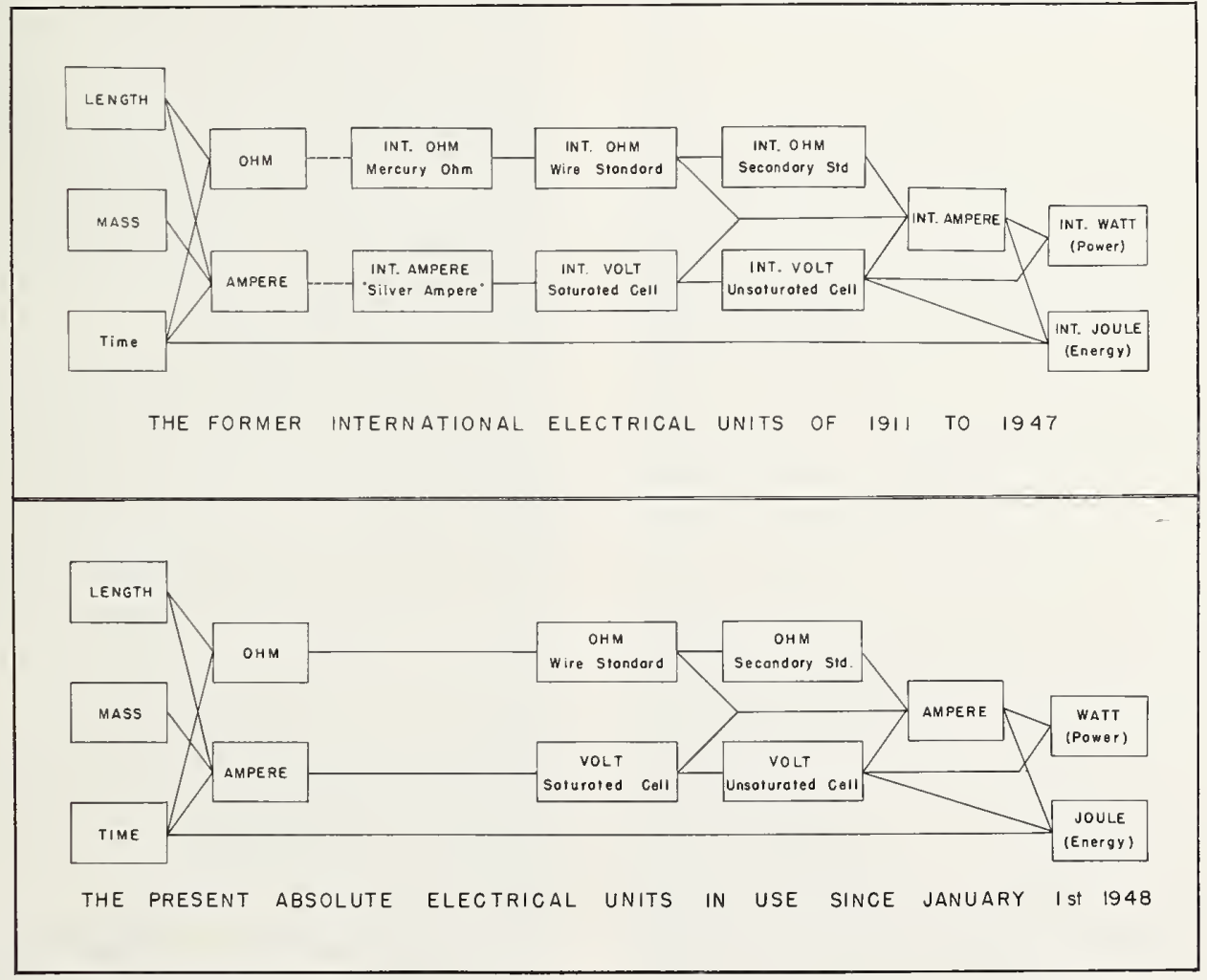

FIGURE 1. Diagram showing the relation of the present and former systems of electrical units to the basic mechanical units of length, mass, and time. 
Chicago International Electrical Congress because specially purified mercurous sulfate had been used in the preparation of the cells; it was $0.0009 \mathrm{~V}$ higher, however, than the value then recommended by Germany). In 1906 the standard consisted of both Clark and Weston Normal cells and after 1908 of Weston cells only; an emf of $1.019126 \mathrm{~V}$ was assigned to the mean of the Weston cells at $20^{\circ} \mathrm{C}$ based on a direct comparison with the Clark cells (on the German basis the emf of the Weston cells was $1.018226 \mathrm{~V}$ which was only slightly lower than $1.0183 \mathrm{~V}$ found in 1910 by the International Committee which met at the National Bureau of Standards). After 1911, this latter unit was maintained in each country until 1948 when "absolute" units were adopted. The number of cells constituting the national standard has varied from time to time; when a cell shows a steady change from its previously steady value it is removed from the group (see later for criterion and procedure).

Today, the National Reference Group of Standard cells consists of 44 saturated Weston (or cadmium sulfate) cells, all of which have been made at the National Bureau of Standards from highly purified materials and assembled under controlled conditions (see later for details). The National Standard is based on the mean emf of these 44 cells. The emf of any one cell in the group is equal to the mean emf, less the average deviation in emf of all 44 cells from the emf of a selected reference cell in the group, plus the deviation in emf of the individual cell from that of the selected reference cell, or

$$
E_{\mathrm{c}}(\text { in volts })=E_{m}-\frac{\Sigma \Delta}{44}+\left(E_{c}-E_{r}\right)
$$

where $E_{c}=$ the emf of an individual cell, $E_{m}=$ the mean emf of the 44 cells, $\Sigma \Delta=$ the algebraic sum. mation of the differences between the emf of a selected reference cell, $E_{r}$, and the emfs of all of the other cells in the group. This reference group (of cells) consists of three parts, of 11 "neutral" cells made in 1906, 7 "acid" $(0.05 \mathrm{~N})$ cells made in 1933 , and 26 "acid" $(0.026 \mathrm{~N})$ cells made in 1948 . The last two groups of cells were added to the reference group in 1937 and 1955, respectively. The meaning of the terms "neutral" and "acid" appears later. This National Reference Group of cells is also supplemented by a group of cadmium sulfate cells made with 98 percent deuterium oxide (heavy water) [36], the emf of which is about $380 \mu \mathrm{V}$ lower than that of cadmium sulfate cells made with normal water. These cells are discussed in Appendix 3 , but suffice it to say here that a study of the ratio of the emfs of cells made with normal and heavy water offers an auxiliary check on the stability of the national unit of emf.

Obviously, all of a group of "identical" cells may increase or decrease in emf with time without departures from the original assigned mean becoming evident. Therefore, an alternative type of standard cell of approximately the same emf as

${ }^{9}$ Measurements of large emf differences of the order of magnitude of $0.3 \mathrm{~V}$ to $0.5 \mathrm{~V}$ with the precision required imposes a problem, though not an insurmountable one. the Weston cell ${ }^{9}$ but of different composition would be most valuable, for if changes in emf with time in two different systems occurred, they would not be likely to follow the same pattern. Thus, studies of the ratio of emfs of two different systems over a period of years would give valuable insight into the stability of the standard. It is for this reason that the National Standard or Reference Group was eventually designed to include "neutral" and "acid" cells ${ }^{10}$ and to be supplemented by cadmium sulfate cells made with heavy water. The ratio of or the difference between the emfs of "neutral" and "acid" cells is followed in the course of maintaining the unit of emf.

A cell is removed from the reference group when its emf has drifted by more than $1.0 \mu \mathrm{V}$ from its previously steady value. When a cell is removed, the mean emf of the group is "recaptured" by reverting in the records to the time the cell had been added to the reference group, calculating a new mean for the reduced group (less the cell removed) at that time, and finally carrying the new mean forward. In some cases it has entailed going back as much as 20 years. Since the cells have closely agreeing emfs the removal of one cell has only a minor effect on the mean emf of the group; this effect has generally been below $1 \mu \mathrm{V}$. The effect on the emf of the mean of removing one cell obviously is smaller the larger is the number of cells in the group (for practical reasons there is a limit to this number; if too high a number, it might not be possible to measure the emfs of all the cells within any one day - this would then increase the problems associated with maintenance).

It is difficult to provide incontrovertible evidence regarding the long-term stability of the volt maintained with saturated standard cells. A considerable body of evidence indicates, however, that it is very unlikely that the unit of emf preserved with the National Reference Group of Standard Cells has changed by any significant amount in the last 53 years. This evidence follows:

(1) In terms of measurements with silver coulometers (or voltameters) and standard resistors - prior to 1948 silver coulometers were used in defining the international ampere (see Appendix 1). To date, however, there are no international specifications that enable the coulometer to be used unambiguously as a means of reproducing the international ampere. Even so, experiments repeated with $a$ given type of coulometer under the same conditions after a lapse of a number of years can serve to establish the same current to high accuracy. From 1910 to 1912, inclusive, [37] a series of experiments were made at the National Bureau of Standards with a Smith form of coulometer and the results were expressed in terms of the emf of the saturated Weston cell at $20^{\circ} \mathrm{C}$; the average of 55 experiments gave $1.018274 \mathrm{~V}$ for the Weston cell at $20^{\circ} \mathrm{C}$. In

\footnotetext{
${ }^{10}$ Cells that differ much more in their chemical composition than "neutral" and "acid" cells or "normal water" and "heavy water" cadmium sulfate cells would be even more desirable for this purpose. However, to date, the prime requirement of constancy in emf has not been as well realized in other systems as it has been in cells
} of the cadmium sulfate type. 
1931 a series of coulometer experiments were conducted at the Physikalisch-Technische Reichsanstalt by representatives from Germany, Great Britain, and the United States [34, 38, 39]; the results obtained by the United States with the Smith form of coulometer gave $1.018273 \mathrm{~V}$ for the Weston cell at $20^{\circ} \mathrm{C} .{ }^{11}$ Assuming that the unit of resistance had not changed during this interval of time the results indicate that the drift in the unit of emf was not over $0.05 \mu \mathrm{V}$ per year.

(2) In terms of measurements with current balances and standard resistors-in 1934 Curtis and Curtis [40] using a current balance originally used by Rosa, Dorsey, and Miller [41] found that I NBS international ampere (given by ratio of NBS units of emf and resistance) was equal to 0.999928 absolute ampere, whereas the results of Rosa et al. in 1911 gave 0.999926 absolute ampere. Accordingly, assuming that the unit of resistance had not changed, these results indicate that any apparent drift in the unit of emf could not have exceeded $0.1 \mu \mathrm{V}$ per year. Also, since 1938 all checks of the NBS unit of emf have agreed within the precision $( \pm 7 \mathrm{ppm})$ of absolute measurements made with current balances or electrodynamometers and self or mutual inductors; these checks indicate that the unit of emf is constant to \pm 0.2 to $\pm 0.3 \mu \mathrm{V}$ per year if the unit of resistance has remained unchanged.

(3) In terms of the gyromagnetic ratio of the proton-in these experiments the precession frequency, as stated above, is measured in a magnetic field known in terms of the absolute ampere and the constant of an accurately made solenoid. The solenoid current, when compared with that given by the ratio of the NBS standards of emf and resistance, has been found to have the same value to better than $0.1 \mu \mathrm{A}$ during the interval from January 1960 to March $1963 .{ }^{12}$ If the unit of resistance remained constant during this period, the unit of emf has also remained constant to better than $0.1 \mu \mathrm{V}$ per year. The construction and properties of standard resistors and standard cells are radically different; the possibility that the two systems should drift in such a manner as to maintain a constant ratio seems remote. The accuracy of absolute resistance measurements has increased significantly in recent times. Modern absolute resistance measurements coupled with reference to atomic constants should, in the foreseeable future, supply convincing evidence regarding the stability of both resistors and cells.

(4) In terms of "neutral" and "acid" cells-the difference between the average emfs of the "neutral" and "acid" cells in the National Reference Group of Standard Cells has increased by $8.5 \mu \mathrm{V}$ in 26 years, with the increase being only $1.0 \mu \mathrm{V}$ during the last 10 years [42]. This comparison was made for 7 "neutral" and 11 "acid" cells, or for cells of

"These results published by Vinal [34] were reported to the fifth decimal and Vinal said "The value for Washington in terms of B.S. unit is, however, exactly the same as the result of the bureau's own experiments on the voltameter [37] published in $1913^{*}$ (actually 1914). These data have been recalculated, retaining the sixth decimal, and are given in Appendix 4.

12 The author is indebted to Forest K. Harris and Raymond L. Driscoll for this information. this type in the National Reference Group since 1937. Since the emfs of "neutral" and "acid" cells have remained relatively constant during the last 10 years the earlier drift in their difference may be attributed to an aging effect exhibited by the "acid" cells (the "neutral" cells were 26 years old at the start of the comparison between the "neutral" and "acid" cells). For the last 10 years the average annual change has been $0.10 \mu \mathrm{V}$.

(5) In terms of international comparisons - in 1948 the units of emf of the United States (USA) and the Bureau International des Poids et Mesures (BIPM) agreed whereas in 1960 the USA unit was $1.9 \mu \mathrm{V}$ smaller than the BIPM unit. Assuming that the BIPM unit had remained constant during this time the USA unit has changed at a rate of $-0.16 \mu \mathrm{V}$ per year. Assuming that the BIPM and USA units changed at the same rates but in opposite directions the USA unit then changed at a rate of $-0.08 \mu \mathrm{V}$ per year. Additional data on international compari. sons are given in section 2.5 .

(6) In terms of customers' cells-customers' saturated cells, checked in terms of the National Standard of emf, show, on the average, an annual variation of $\pm 1.2 \mu \mathrm{V}$ per year, but no drifts in emf in one direction or the other. This relative stability refers only to cells that are about 3 or more years of age; saturated standard cells usually exhibit an aging effect of several microvolts during the first 3 years after their construction.

(7) In terms of newly prepared cells-saturated standard cells freshly made from new materials usually agree with old or aged cells within $5 \mu \mathrm{V}$. Of course, in this type of comparison the cells must be made with amalgams of the same percentage of cadmium and with cadmium sulfate solutions of the same acidity with respect to sulfuric acid. The point here is that saturated cadmium cells, made at different times to essentially the same specification, are highly reproducible. Cells made in the past cannot have drifted seriously in emf if similar cells of recent construction agree closely in emf with them.

(8) In terms of the relative emfs of cells within a group of cells-the differences in emf between the cells in the National Reference Group of Standard Cells have remained remarkably constant for decades. Although, as stated above, all "identical" cells may increase or decrease in emf without evident departures from their mean emf, constancy in the difference between the emf of individual cells in a group of cells with time nevertheless, in combination with items (1), (2), and (3) above, increases confidence in the constancy of the mean emf of a group of cells.

Although the above remarks apply to the stability of standard cells in the National Reference Group of Standard Cells they should also apply to any standard cell of the saturated type providing it is a quality cell properly maintained. Cells made with impure materials or poorly assembled will invaria. bly show much less stability in emf. In section 2.5 the need for adjustments in the assigned values to 
standard cells, although infrequent, is discussed. The need for these adjustments is not clear. It may be that the cells were of poor quality, were affected by transport, or had not come to equilibrium after temperature changes which are involved in international comparisons.

The standard cells of the National Reference Group are housed in slowly stirred oil baths maintained at $28{ }^{\circ} \mathrm{C}$ under diffuse light in an air-conditioned room maintained at $25{ }^{\circ} \mathrm{C} \pm 1{ }^{\circ} \mathrm{C}$; the relative humidity automatically remains below 50 percent. The temperature of the baths is maintained at $28^{\circ} \mathrm{C}$ within $0.01{ }^{\circ} \mathrm{C}$ on a long-term basis and within 0.001 ${ }^{\circ} \mathrm{C}$ during measurements using a Gouy controller [43]. In a Gouy controller, a steel piano wire extending into the mercury of the mercury-toluene regulator is connected to a wheel which revolves at a slow rate whereby the wire is made to periodically make and break contact with the mercury. The design of the bath and its temperature control are described in Appendix 5. A special mineral oil, having the characteristics listed in Appendix 6, is used as fluid in the constant-temperature baths. Tests made to determine the temperature of the oil at various locations within the baths indicated a uniform temperature within $0.001{ }^{\circ} \mathrm{C}$, i.e., no hot or cold spots prevail within the bath or in the vicinity of the standard cells. This design follows closely that described many years ago by Wolff and Waters [44]. A bath for use with saturated standard cells has also been described recently by $\mathrm{P} . \mathrm{H}$. Lowrie, Jr. [45].

The cells are supported about 2 in. below the surface of the oil on seasoned mahogany strips about $16 \mathrm{~mm}$ wide (slightly smaller than the distance between the limbs of NBS $\mathrm{H}$-shaped cells) and about $10 \mathrm{~mm}$ thick and either 24 or $48 \mathrm{~cm}$ long, with grooves into which the cross-arms of the cells fit snugly. Some racks carry 18 cells equally spaced, except for a somewhat wider space at the middle of the rack where the rack is supported; others carry 9 cells. Hard rubber, bakelite, or lucite strips

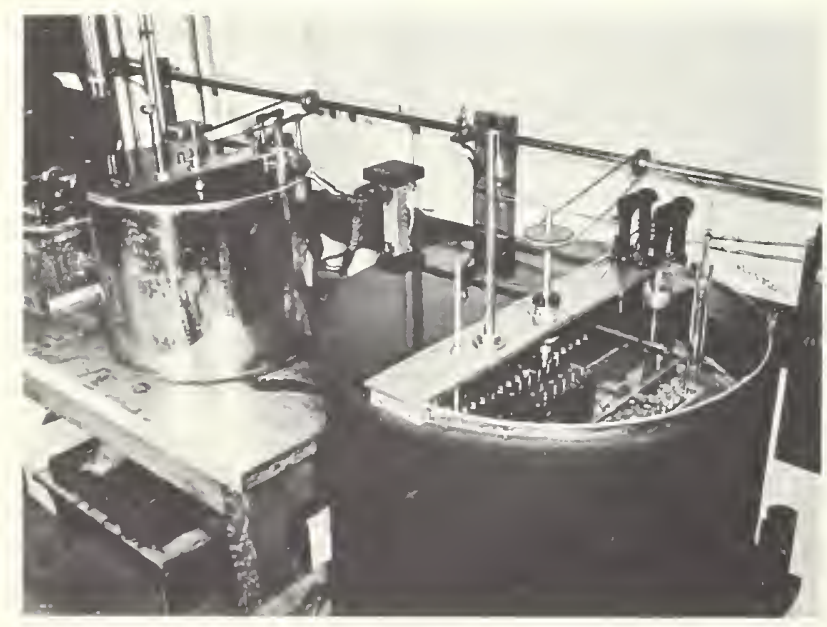

Figure 2. Oil baths used to house the National Reference Group of Standard Cells. (widened U-shaped), about $40 \mathrm{~mm}$ long, $10 \mathrm{~mm}$ wide, and $10 \mathrm{~mm}$ thick in the center and $13 \mathrm{~mm}$ at each end, are mounted between cells across the underedge of the mahogany strip. In the top of each strip, at each end, is inserted a short copper rod provided with a pair of holes, one $1 \mathrm{~mm}$ and the other $2 \mathrm{~mm}$ in diameter and both about $9 \mathrm{~mm}$ in depth; these holes serve as mercury cups, one for a cell terminal and the other for external connections. These two copper cups are spaced at the same distance apart on each strip, so that any cell can be put in the electric circuit by a stabber consisting of a pair of stiff copper wires mounted in a lucite block (copper wires are amalgamated on the tips). This is a copper-copper connection through the mercury and under the oil. From this point on all contacts are copper-copper to avoid thermal emfs. The other end of the stabber connection goes to a post position. There are two post positions, one for the Reference Cell and one for the Unknown Cell. The leads of the cells go from the posts through conduits to another post at the emf-measuring instrument (see later), where the two cells are placed in series opposition by joining the negatives and the difference is measured.

A photograph showing the oil baths that house the National Reference Group of Cells is shown in figure 2. Other baths of intermediate size are also available for housing cells on test. The temperature of the baths is measured with a platinumresistance thermometer and a Mueller bridge, having a sensitivity of $0.0001 \mathrm{ohm}$, corresponding to $0.001{ }^{\circ} \mathrm{C}$.

\subsection{Dissemination}

Comparisons of the emf of standard cells, such as may be required in the dissemination of the unit of emf, i.e., the transfer of the unit from a standardizing laboratory, must or should be carried out by procedures of the highest precision involving a minimum of uncertainty. In this case, comparisons are made between standard cells, the emf of which have been determined in absolute units and other standard cells, the emf of which have not been so determined. The former may be called reference cells and the latter unknown cells. These intercomparisons may be made with high accuracy with potentiometers by the opposition method (preferably called the difference method). In this method the two cells (reference and unknown) are connected in series with their emfs in opposition and the difference in emf between the two is measured with a potentiometer using a galvanometer of high sensitivity. Because the difference in emf between the two cells is small, only a moderate percentage accuracy in its determination is required to give the emf of the unknown cell accurately in terms of the known reference cell. If the difference between - the two cells were $100 \mu \mathrm{V}$ the accuracy of the measurements need be only 1 percent to give the difference to $1 \mu \mathrm{V}$ or only 0.1 percent to give an accuracy of $0.1 \mu \mathrm{V}$.

This method is not direct reading, however, and 
the operator must determine which of the two cells has the higher emf. The greatest source of error in measurements by the difference method is the presence in the circuit of spurious emfs, such as those from thermoelectric action. At the National Bureau of Standards a special comparator, designed by Brooks [46], is used. This comparator is direct reading and compensates for parasitic thermal emfs. The reference and unknown cells are connected in series-opposition in series with a galvanometer and an auxiliary source of a few microvolts and adjustments are made in the auxiliary source until the galvanometer indicates a null balance. The D'Arsonval galvanometer (see $\mathrm{G}_{1}$, figure 3 ) used with the comparator has a free period of $8 \mathrm{sec}$, an external damping resistance of $1200 \mathrm{ohms}$, and a sensitivity of $5 \mathrm{~mm}$ per microvolt at one meter lamp and scale distance when operated slightly underdamped.

With the Brooks comparator, differences in emf as large as $2100 \mu \mathrm{V}$ may be read with a precision of $0.1 \mu \mathrm{V}$. The Brooks comparator contains an opposing circuit for the detection and compensation of thermal emfs in the galvanometer circuit, contains no sliding parts in the main circuit, and has a "read-out" device by which the measured difference in the emf is added algebraically to the emf of the reference cell thereby giving directly the entire emf of the unknown cell.

A circuit illustrating the principle of the Brooks comparator is shown diagrammatically in figure 3 and the exterior and interior of the comparator are shown in figures 4 and 5 , respectively. The uppermost of the three sections shown in figure 3 relates to the adjustment of the current in the comparator to the proper value. A current $I_{1}$ from battery $B_{1}$ (No. 6 dry cell) is regulated by the rheostat $R_{1}$ to a definite value in the usual manner by reference to an auxiliary standard cell. All parts with exception of the battery are housed in the comparator. In the middle section, the substitution resistances connected to tap points numbered 3 to 16 are selected by the central dial as needed. Each step is $100 \mu \mathrm{V}$. It is necessary to interpolate between successive steps to complete the process of measuring the emf of the unknown cell, $X$ (lower section). This is done automatically by the circuits attached to points 17 and 18. $B_{2}$ and $B_{3}$ are No. 6 dry cells, also. The milliammeter $A_{3}$ measures the current $I_{3}$ when an exact balance is indicated by the galvanometer $G_{1}$ as a result of varying the resistance $R_{3}$. The milliammeter $A_{3}$ is calibrated to make its scale read directly in microvolts. A similar circuit attached at 1 and 2 performs a like function for the reference cell $N$ (lower section) whose emf value must be set exactly if the readings for the unknown cell $X$ are to be correctly determined. The lowest section of figure 3 shows the circuit wherein the unknown, $X$, and the reference cell, $N$, are connected in series opposition. This circuit also contains the galvanometer, $G_{1}$, of sensitivity, given above.

Thermal emf compensation is achieved by a simple copper slide wire connected in series with the main galvanometer, $G_{1}$. About $15 \mu \mathrm{A}$ from a No. 6 dry cell (not shown in the figure) enters this slide wire at its central point and leaves by a slider. If the slider is set at the central point of the copper wire there is no current in the copper wire and, therefore, no potential drop. By setting the slider away from the central point, a small adjustable potential drop may be introduced into the galva-

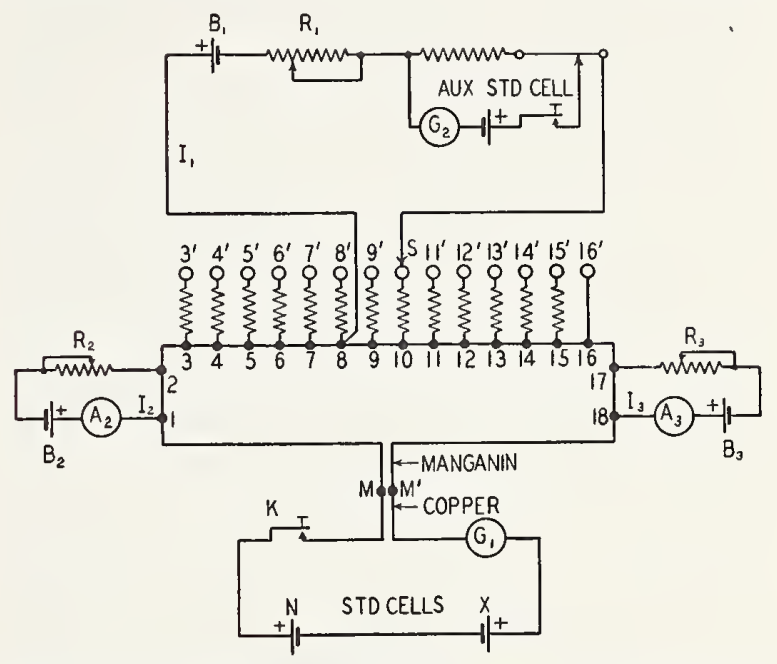

Figure 3. Diagrammatic plan of circuits illustrating the principle of the potentiometric part of a Brooks standard-cell comparator.

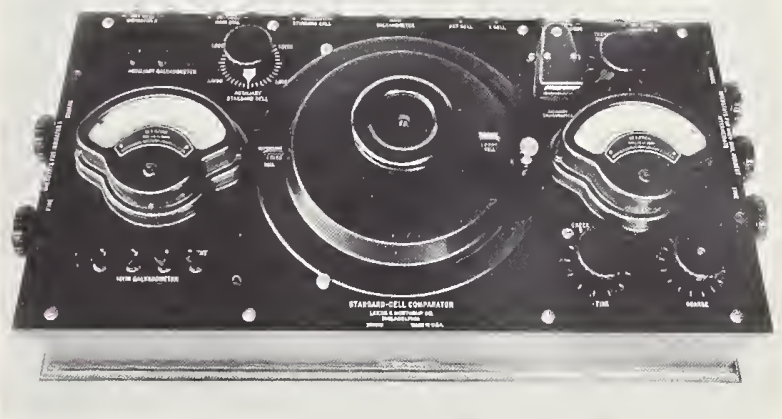

Figure 4. Photograph of a Brooks comparator (top view).

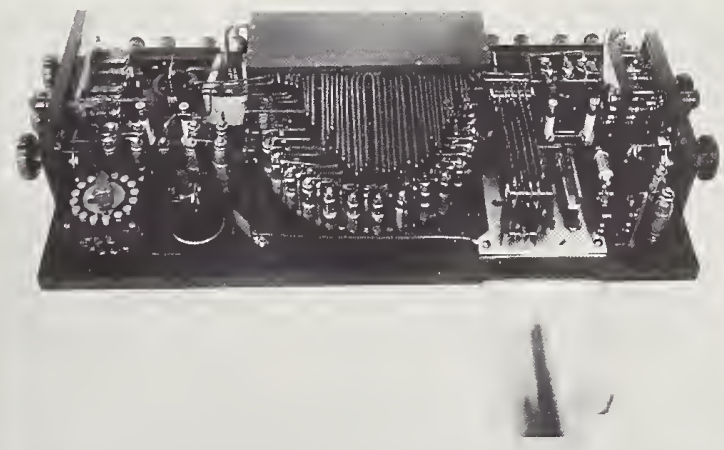

FiguRE 5. Photograph of the interior of a Brooks comparator. 
nometer circuit to neutralize any parasitic emf in the galvanometer and the wires connecting it to the comparator. By depressing a "shunt" key any appreciable parasitic emf can be detected: if present it will maintain a corresponding deflection of the galvanometer and when the "shunt" key is depressed the galvanometer coil will assume its opencircuit zero position. To neutralize this undesired emf the slider is manipulated until no motion of the galvanometer coil ensues when the "shunt" key is depressed. For additional details the original paper by Brooks [46] should be consulted.

Although compensation for thermal effects is provided in the instrument, thermal effects may also arise at the cell terminals. These are eliminated by making connections to the cells through mercury cups immersed two inches below the surface of oil maintained at the same temperature as the cells, as was mentioned above under maintenance (section 2.3). In those cases (for example, unsaturated cells or saturated cells in air boxes; see later) where the terminals of the unknown cell cannot be immersed in oil, thermal effects are kept at a minimum by using like metal connections in a constanttemperature room. Other types of standard cell comparators have been described by Miller [47], Vincent [48], and by Spinks and Hermach [49]. The comparator (portable potentiometer) of Spinks and Hermach also includes two saturated and two unsaturated standard cells in a temperaturecontrolled enclosure.

In the dissemination of the unit of emf, i.e., the comparison of unknown and reference cells, working groups of standard cells are used instead of the National Reference Group of Standard Cells. Of course, the emfs of the cells within these working groups are known in terms of the National Reference Group. These comparisons are made with a precision of $0.6 \mu \mathrm{V}$. One working group is maintained in the Standard Cell Laboratory in Washington, D.C., the other at the NBS Boulder Laboratories in Boulder, Colo. [50]. A total of 10 comparisons of the emf of the unknown (customer) cells with the working groups is made, one per day, over a period of ten days, at a specified temperature for saturated cells and at an ambient temperature of $25^{\circ} \mathrm{C}$ (at Washington) and of $23^{\circ} \mathrm{C}$ (at Boulder) for unsaturated cells. ${ }^{13}$ The best saturated cells are calibrated with an uncertainty of 0.0001 percent; the best unsaturated cells with an uncertainty of 0.005 percent. The results are transmitted to customers in Reports of Calibration.

\subsection{International Comparisons}

Since 1932 the units of emf of various nations have been intercompared at specified intervals at the Bureau International des Poids et Mesures (BIPM), Sèvres, France. At the present time this interval is 3 years. For many years the comparisons were rather sporadic, and they were interrupted by the

13 The National Bureau of Standards provides emf calibrations of unsaturated standard cells only for public utilities and others having operations of such a nature as to require calibrations by the National Bureau of Standards.

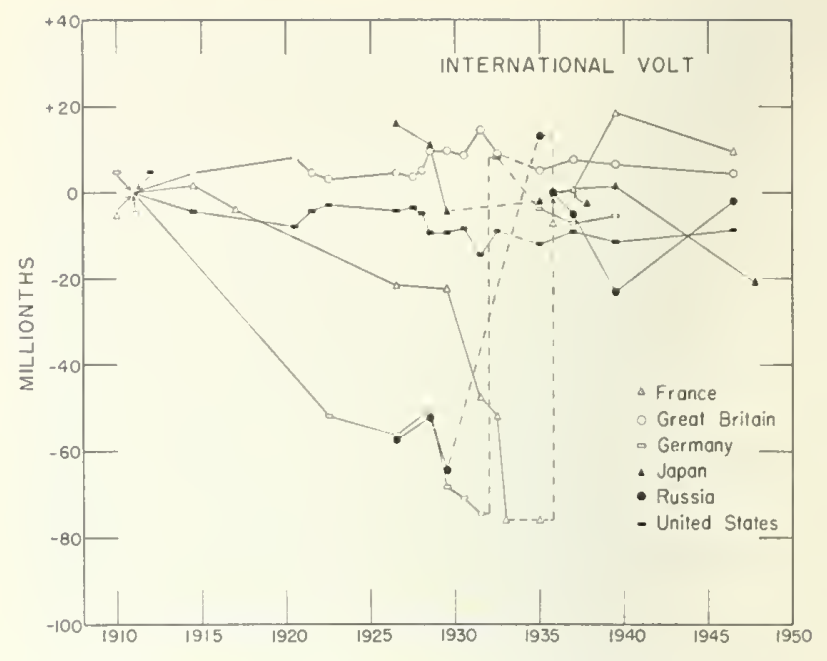

FIGURE 6. International comparisons of the unit of electromotive force in international volts prior to 1948.

two World Wars (see fig. 6). Prior to 1948 the intercomparisons were made in "international volts" and since 1948 in "absolute volts" (see figs. 6 and 7). These intercomparisons are effected by standard cells maintained by the participating countries and by the International Bureau and are conducted at $20^{\circ} \mathrm{C}$. As a rule each country submits 4 to 10 cells to BIPM for the intercomparisons; at the present time the cells are carried to BIPM by messenger.

The first comparison involved the measurements at the National Bureau of Standards in 1910, at which time the units of the participating countries, France, Germany, Great Britain, and the United States were identical (see fig. 6). From 1911 to 1932 the major intercomparisons were between the units as maintained in the United States and in Great Britain. In preparing figure 6 it was assumed that the mean value for these two nations remained constant and this mean is made the axis of abscissas. A few comparisons were also made of the United States unit with those of France, Germany, Japan, and Russia and are shown in figure 6 in terms of the mean unit of the United States and Great Britain. In 1931 it was apparent that there was an increasing discrepancy between the unit as maintained in Germany at the Physikalisch-Technische Reichsanstalt (or PTR) in Charlottenburg and those maintained in the United States at the National Bureau of Standards (or NBS) in Washington, D.C., and in Great Britain at the National Physical Laboratory (or NPL) in Teddington. Consequently, at the invitation of the PTR arrangements were made to have an international committee carry out experiments with the silver coulometer at PTR and thus reestablish the international volt. Accordingly, P. Vigoureux of NPL and G. W. Vinal of NBS took silver coulometers to the PTR together with standard cells and standard resistors, the values of which had been carefully determined at their respective laboratories. At the PTR, these standards were compared with those of the PTR and an extensive series of experiments with different types 
of silver coulometers were made. As a result of these measurements, subsequently published [34, $38,39]$, Germany increased its unit by $82 \mathrm{ppm}$ (see Appendix 4 for United States data).

As a result of extensive work on silver coulometers by Kolossov [51], Russia changed its unit in 1934 by $87 \mathrm{ppm}$.

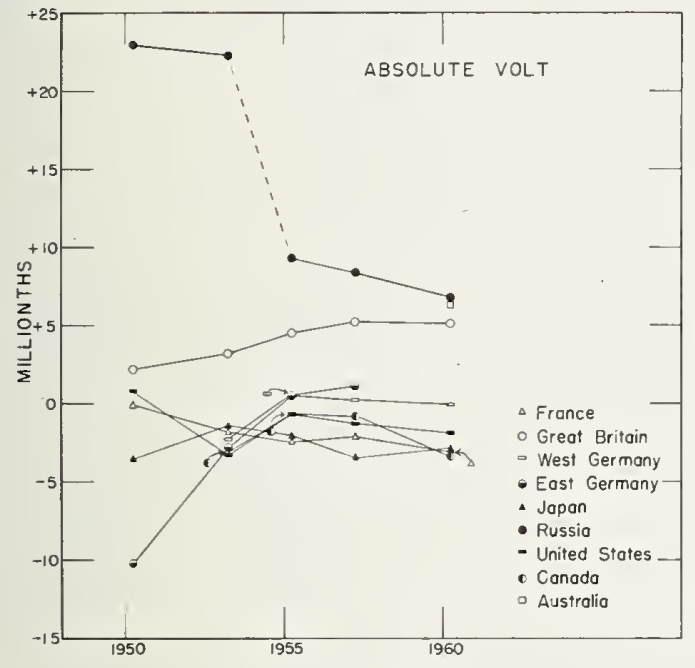

FIGURE 7. International comparisons of the unit of electromotive force in absolute volts since 1948.

International comparisons at BIPM began in 1932 [52] and after 1934 the data in figure 6 are plotted on the assumption that the "Mean International Volt" as defined in 1935 by the Consultative Committee on Electricity [53] has remained constant. In December 1934 the six countries listed in figure 6 submitted cells to BIPM. France, on finding its unit out of line from the others, increased its unit by $76 \mathrm{ppm}$ in 1935 . The Consultative Committee on Electricity suggested that the mean unit of the five remaining countries be adopted by all thus assuring immediate unification. However, only Russia accepted this suggestion and reduced its unit by 13 ppm. In 1937, 1939, and 1945-48, BIPM carried forward its mean value obtained in 1935 for the six countries after correcting for the Russian adjustment; this adjustment made the BIPM unit $2.2 \mathrm{ppm}$ lower than its 1935 unit; the data in figure 6 are so reported. For the last comparison in international volts the National Physical Laboratory sub. mitted cells in 1945 and the comparison with BIPM was completed in 1946; the other countries submitted cells in 1948 and the comparisons with BIPM were done the same year. Russia reported its values in absolute units using the international relation: 1 mean international volt $=1.00034 \mathrm{ab}-$ solute volts. In 1939 the Russian unit had been $23.1 \mu \mathrm{V}$ below the mean international unit. For comparisons with other countries and assuming that this difference still applied, BIPM converted the Russian absolute values to international values using a conversion factor of 1.000317 .

On January 1, 1948, "absolute" units were adopted but international comparisons on this basis were not made until 1950. Intercomparisons in the "absolute" units, obtained since 1950, are given in figure 7 (note that the scale in figure 7 is much larger than in figure 6); Australia and Canada were new additions. In 1950 the German value was from East Germany while in 1953, 1955, and 1957 both East and West Germany took part in the international comparisons; since 1957 the German value is for West Germany. The data shown in figure 7 are the deviations from the BIPM mean value. In 1950 Russia had apparently corrected their "absolute" values of 1948 by the average deviations of the various countries, Russia excepted, from the BIPM unit, thus, ignoring the fact that their unit had been $23.1 \mu \mathrm{V}$ below the mean international unit in 1939; this procedure, then placed their unit in 1950 above the BIPM unit by approximately this magnitude. In 1955 Russia made an adjustment in its unit of about $13 \mu \mathrm{V}$. In 1960 the spread between the 8 countries was $10.2 \mu \mathrm{V}$ with the units of Australia, Great Britain, and Russia being high. The spread between the other 5 countries was $3.3 \mu \mathrm{V}$. In 1960 , values for Italian cells were included with the values listed with the French cells; France had first made a direct comparison of the Italian cells with their cells at the Laboratoire Central d'Electricité, Fontenay-aux-Roses, France.

\section{Early Standard Cells}

Many types of galvanic cells have been proposed as standards of emf and some of these have appeared in a variety of forms. Although Faraday and others of his time used various galvanic cells, such as Grove and Bunsen cells, in their investigations, the Daniell cell [54] represented by

$$
(-) \mathrm{Zn}(\mathrm{s})\left|\mathrm{ZnSO}_{4}, \mathrm{H}_{2} \mathrm{SO}_{4}(\mathrm{aq}) \| \mathrm{CuSO}_{4}(\mathrm{aq})\right| \mathrm{Cu}(\mathrm{s})(+)
$$

was the first cell seriously used as a standard of emf, as it exhibited less gassing than its predecessors. Here a single vertical line is used to indicate the interface of two distinct phases, a double vertical line to indicate a liquid-liquid junction, $s=$ solid, and aq = aqueous solution. However, this type of cell did not exhibit a long-term stability in emf. Being a two-fluid cell, the solutions diffused into each other causing local action at the electrodes and a steady decrease in emf. Somewhat better results were obtained when saturated solutions, no acid, and amalgamated zinc were used, but, even so, the cells did not exhibit the permanency required in a standard. Nevertheless, for over 35 years, Daniell cells were used as a standard of emf. Absolute electrical measurements gave 1.07 to $1.14 \mathrm{~V}$ for the emf of freshly prepared cells; the actual value depended on the concentration and acidity of the solutions used. Absolute measurements were not needed to show the lack of constancy in the emf of the cells; this 
behavior was evident from comparing new cells with old ones. The cell reaction is

$$
\mathrm{Zn}(\mathrm{s})+\mathrm{CuSO}_{4}(\mathrm{aq}) \rightarrow \mathrm{ZnSO}_{4}(\mathrm{aq})+\mathrm{Cu}(\mathrm{s})
$$

The Daniell cell has an emf-temperature coefficient of about $+34 \mu \mathrm{V} / \mathrm{deg} \mathrm{C}$ at room temperature (18 to $\left.30{ }^{\circ} \mathrm{C}\right)$.

Daniell cells were made in various forms. The original form consisted of a glass jar containing a porous pot of unglazed earthenware in which a zinc plate or rod was placed. Outside and around the pot a cylindrical sheet of copper was placed. The outer jar was filled with a concentrated solution of copper sulfate and the porous pot with dilute sulfuric acid, or zinc sulfate, or zinc sulfate acidified with sulfuric acid [55]. lmportant modifications were the gravity [56] and Fleming-Thomson cells [57]. In the gravity cell the less dense solution of zinc sulfate was placed over the more dense solution of copper sulfate so that the porous cup was eliminated. Zinc in circular or crow-foot form and copper in leaf form were used as electrodes in their respective salt solutions. In practice the cell was kept on closed circuit to curtail the mixing of the two solutions. In the Fleming-Thomson cell a U-tube was used containing a solution of copper sulfate in one arm and a solution of zinc sulfate of the same density in the other arm. Rods of copper and zinc were supported in their respective salt solutions.

In 1872 Latimer Clark [23] proposed a cell which had a profound effect on work pertaining to the electrical units. His cell, represented by

$(-) \mathrm{Zn}(s)\left|\mathrm{ZnSO}_{4} \cdot 7 \mathrm{H}_{2} \mathrm{O}(\mathrm{c})\right| \mathrm{ZnSO}_{4}($ sat aq $) \mid \mathrm{ZnSO}_{4}$

$$
\cdot 7 \mathrm{H}_{2} \mathrm{O}(c)\left|\mathrm{Hg}_{2} \mathrm{SO}_{4}(\mathrm{~s})\right| \mathrm{Hg}(l)(+)
$$

where $c=$ crystals, $s=$ solid, $l=$ liquid, and sat $\mathrm{aq}=$ saturated aqueous solution, was a one-fluid cell free of a liquid-liquid junction and exhibited relatively good stability in emf. Because of the historical importance of the Clark cell (see sec. 2) it is discussed in more detail in section 4. Owing to the success that was obtained with the Clark cell several other one-fluid cells were proposed as standards, the more important being those suggested by De la Rue [58], Helmholtz [59], Gouy [60], and Weston [30]. Of these four the first three exhibited larger drifts in emf and had higher internal resistances than Clark cells, while the last one had many advantages over the Clark cell. As a result, Weston cells are now used almost exclusively as standards of emf. Weston cells had an emftemperature coefficient about 1/30th of that of the Clark cell, better emf stability, and an emf closer to unity than the Clark cell.

Early types of standard cells are listed in abbreviated form in table 2 together with their nominal emf and emf-temperature coefficient. As is evident from the table the Weston cell is similar to the Clark cell except that $\mathrm{Cd}$ replaces $\mathrm{Zn}$. In all of these cells, the original Clark cell excepted, amalgamated anodes were generally recommended and $\mathrm{H}$-shaped containers (see below) were frequently used. In general, saturated solutions were used and excess crystals of the stable salt added to the cells at the electrode surfaces. Weston [61] and Carhart [62] proposed the use of an unsaturated solution of zinc sulfate in the Clark cell in order to decrease its emf-temperature coefficient. The original Weston patents also covered the unsaturated form of Weston cell.

TABLE 2. Early types of standarel cells

\begin{tabular}{|c|c|c|c|c|}
\hline Name & Date & System & $\begin{array}{l}\text { Approximate } \\
\text { emf, vilts }\end{array}$ & $\begin{array}{c}\text { Approximate } d E / d t \text {. } \\
\text { volt per deg } C\end{array}$ \\
\hline Daniell & 1836 & $\mathrm{Zn}\left|\mathrm{ZnSO}_{4}\right|\left|\mathrm{CuSO}_{4}\right| \mathrm{Cu}$ & $1.0 .1-1.14(n)^{1}$ & $+0.000034(n)$ \\
\hline Clark & 1872 & $\mathrm{Zn}\left|\mathrm{ZnSO}_{4}\right| \mathrm{H}_{52} \mathrm{SO}_{4} \mid \mathrm{Hg}_{\mathrm{g}}$ & $1.433\left(15^{\circ} \mathrm{C}\right)$ & $-0.0012\left(15^{\circ} \mathrm{C}\right)$ \\
\hline De la Rue & 1878 & $\mathrm{Zn}\left|\mathrm{ZnCl}_{2}\right| \mathrm{AgCl} \mid \mathrm{Ag}$ & $1.03(n)$ & $-0.001(n)$ \\
\hline Helmholtz & 1882 & $\mathrm{Zn}\left|\mathrm{ZnCl}_{2}\right| \mathrm{HgCl}_{\mathrm{g}} \mid \mathrm{Hg}$ & $1.000\left(15^{\circ} \mathrm{C}\right)$ & $+0.000087(n)$ \\
\hline Gouy & 1888 & $\mathrm{Zn}\left|\mathrm{ZnSO}_{4}\right| \mathrm{HgO} \mid \mathrm{Hg}$ & $1.390\left(12^{\circ} \mathrm{C}\right)$ & $-0.0014(n)$ \\
\hline Weston & 1892 & $\mathrm{Cd}\left|\mathrm{CdSO}_{4}\right| \mathrm{Hg}_{2} \mathrm{SO}_{4} \mid \mathrm{Hg}_{\mathrm{g}}$ & $1.01864\left(20^{\circ} \mathrm{C}\right)$ & $-0.000041\left(20^{\circ} \mathrm{C}\right)$ \\
\hline
\end{tabular}

(represented in abbreviated form)

$1-n$ represents nominal value at room temperature (about 18 to $30^{\circ} \mathrm{C}$ ).

Somewhat later Brönsted [63] proposed the cell: $(-) \mathrm{Pb}, \mathrm{Hg}(l)\left|\mathrm{K}_{2} \mathrm{SO}_{4} \cdot \mathrm{PbSO}_{4}(c)\right| \mathrm{K}_{2} \mathrm{SO}_{4}($ sat aq $)\left|\mathrm{Hg}_{2} \mathrm{SO}_{4}(s)\right| \mathrm{Hg}(l)(+)$

as a standard, stating that at $22^{\circ} \mathrm{C}$ it had an average emf of $1.0481 \mathrm{~V}$ and an emf-temperature coefficient of $-0.0001 \mathrm{~V} / \mathrm{deg}$ C. Henderson and Stegeman [64], however, stated that the Brönsted cell did not exhibit steady emfs with time and that better results were obtained when $\mathrm{Na}_{2} \mathrm{SO}_{4}$ was used as the electrolyte. However, their cell at $25^{\circ} \mathrm{C}$ had a lower emf of $0.96463 \mathrm{~V}$ and a higher emf-temperature coefficient of $+0.000174 \mathrm{~V} / \mathrm{deg} \mathrm{C}$. These cells have not been used probably because of their high emf-temperature coefficients. Vosburgh, Guagenty, and Clayton [65] proposed the cell:

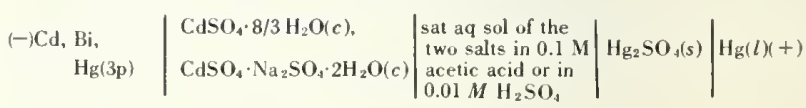

which is a modified Weston cell in which a 3-phase (3p) amalgam (8.9 percent $\mathrm{Cd}, 11.1$ percent $\mathrm{Bi}, 80$ percent $\mathrm{Hg}$ ) and a $0.1 \mathrm{M}$ acetic acid or $0.01 \mathrm{M} \mathrm{H}_{2} \mathrm{SO}_{4}$ solution saturated with the two salts, as indicated, are used. The cells were sealed with a nitrogen atmosphere inside. At $25^{\circ} \mathrm{C}$ they reported an average emf of $1.0184 \mathrm{~V}$ and an emf-temperature coefficient of $+0.000013 \mathrm{~V} / \mathrm{deg} \mathrm{C}$ which is about 2 to 10 times that of unsaturated Weston cells but less than one-third of that of the saturated Weston cell at 20 to $30^{\circ} \mathrm{C}$ but of opposite sign. Data available on this cell indicate that it does not have the long-term stability exhibited by saturated Weston cells, but compares most favorably with the unsaturated type [66]. 


\section{The Clark Cell}

As stated above, the original Clark cells consisted of a zinc anode and a mercury-mercurous sulfate cathode in a saturated solution of zinc sulfate containing crystals of $\mathrm{ZnSO}_{4} \cdot 7 \mathrm{H}_{2} \mathrm{O}$. Clark used a very simple construction as shown by (a) in figure 8. Various modifications of this general construction were used in commercial cells; one such modification being the British Board of Trade cell illustrated by (b) in figure 8 . In all of these the zinc anode was in contact with the paste consisting of mercurous sulfate, a saturated solution of zinc sulfate, and crystals of $\mathrm{ZnSO}_{4} \cdot 7 \mathrm{H}_{2} \mathrm{O}$.

Clark determined the emf of his cell in absolute units with (a) a sine galvanometer and (b) an electrodynamometer and a B. A. resistor (see footnote 7, p. 4). With these he obtained $1.45735 \mathrm{~V}$ and $1.45761 \mathrm{~V}$, respectively, at $15.5^{\circ} \mathrm{C}$, the mean of which he rounded to $1.457 \mathrm{~V}$ as the absolute emf of his cell. Clark's cell, although much better as a standard than the two-fluid cells, did not show the permanency in emf hoped for. The cell tended to gas at the zinc anode and the emf showed large variations owing mainly to concentration gradients that developed, during slight changes in ambient temperatures, within the compact paste.

In 1884 Rayleigh and Sidgwick [24] introduced two modifications in the Clark cell that resulted in substantial improvements. They substituted zinc amalgam (percentage not stated) ${ }^{14}$ for zinc and used an $\mathrm{H}$-shaped container in which the zinc anode could be kept entirely under solution and out of contact with the mercurous sulfate paste. Their design is illustrated by (c) in figure 8 . The zinc amalgam reduced the rate of gassing at the anode and by being under solution and out of contact with the mercurous sulfate paste the zinc anode exhibited more nearly constant potentials. Rayleigh and Sidgwick obtained $1.453 \mathrm{~V}$ for the absolute emf of their cells at $15^{\circ} \mathrm{C}$ using a current balance (now known as a Rayleigh balance) and a B.A. resistor.

\footnotetext{
${ }^{14}$ Rayleigh and Sidgwick presented their paper in June 1884; in the paper published in Dec. 1884 they added the note "Some H-cells have been set up Mr. Threlfall, with amalgams of known composition, varying from 1/32 zinc to 1/5 zinc by weight. The duration of the test has as yet been scarcely adequate, but it appears that the sinall quantity of with 7 to 10 percent amalgams.
}

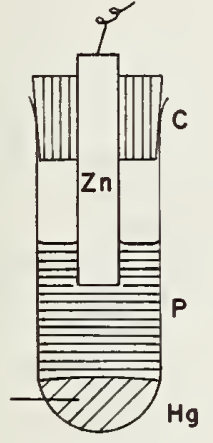

(a)

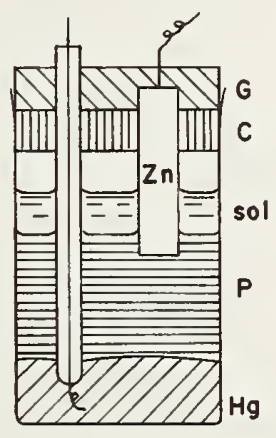

(b)

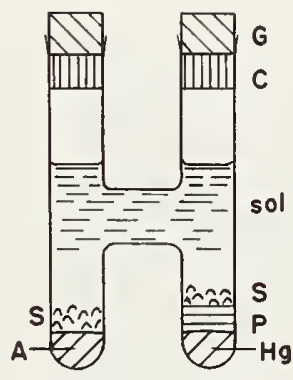

(c)

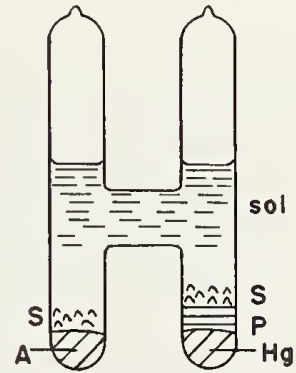

(d)

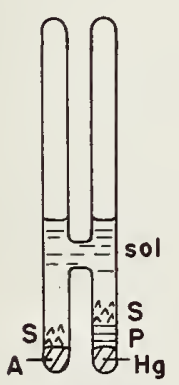

(e)

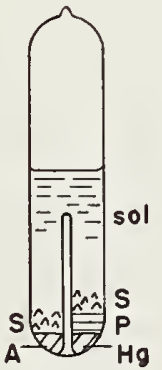

(f)

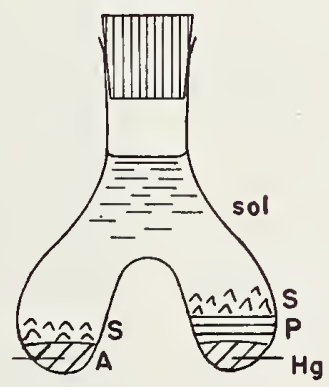

(g)

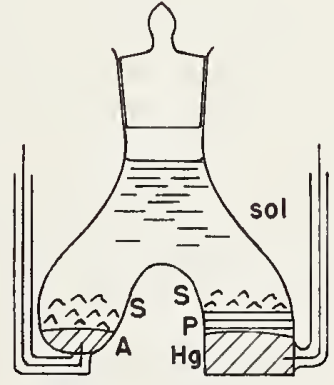

(h)

FigURE 8. Various forms of standard cell containers.
(a) Original Clark cell
(b) Board of Trade (British) Clark cell
(c) Rayleigh-Sidgwick $\mathrm{H}$-shaped Weston cell
(d) Sealed $\mathrm{H}$-shaped cell
(e) Hulett $\mathrm{H}$-shaped cell
(f) Modified Hulett container
(h) Cooper container

$\mathrm{Zn}$-zine

$\mathrm{Hg}$ - mercury

$\mathrm{P}$-mercurous sulfate paste

C-cork

sol-glue

A-amalgam

S-salt crystals 
These cells tended to leak in time, and Callendar and Barnes [67] recommended their hermetic sealing, (d) in figure 8 . Other types of cell containers, also used for Weston cells, have been proposed and are illustrated in figure 8 . Hulett [68] proposed a shorter crossarm (e) and today some cells are made with no crossarm but with a partition at the base of a single tube (f). Wright and Thompson [69] proposed the inverted-Y form, hermetically sealed, and Kahle [70] the same form but with a cork or groundglass stopper (g); these are more difficult to fill. Cooper [71] proposed a modified Kahle type (h) which required no support in a thermostaticallycontrolled bath; his form could rest on a flat surface without support. The Cooper cell could also be used in water as well as in non-conducting oil because the cell terminals were not exposed but protruded above the bath fluid. Today, the H-shaped container, hermetically sealed, is used most widely; some single-tube types, either like (f) or in a modified form of the original design (a) are also made.

The reaction in the saturated Clark cell made with amalgamated anodes is:

$$
\begin{array}{r}
x \mathrm{Zn},(y \mathrm{Hg})(2 p)+\mathrm{Hg}_{2} \mathrm{SO}_{4}(s)+\frac{7}{m-7}\left(\mathrm{ZnSO}_{4} \cdot m \mathrm{H}_{2} \mathrm{O}\right)(\mathrm{sat} \text { aq }) \\
=\frac{m}{m-7}\left(\mathrm{ZnSO}_{4} \cdot 7 \mathrm{H}_{2} \mathrm{O}\right)(c)+2 \mathrm{Hg}(l)+(x-1) \mathrm{Zn}, y \mathrm{Hg}(2 p)
\end{array}
$$

where $x=$ moles of $\mathrm{Zn}$ associated with $y$ moles of $\mathrm{Hg}$ in the amalgam, $2 p=2$-phase, and $m$ is the number of moles of water associated with 1 mole of $\mathrm{ZnSO}_{4}$ in the saturated solution. Ten-percent amalgams are most commonly used; they are of two phases, solid and liquid, with the solid phase being pure zinc (see fig. 9) [72]. The composition of the liquid phase of a 10 percent zinc amalgam at various temperatures is given in column 2 of table 3.

The solubility of zinc sulfate in water changes considerably with temperature. Above $39{ }^{\circ} \mathrm{C}$ the stable sulfate is $\mathrm{ZnSO}_{4} \cdot 6 \mathrm{H}_{2} \mathrm{O}$; below $39{ }^{\circ} \mathrm{C}$ it is $\mathrm{ZnSO}_{4} \cdot 7 \mathrm{H}_{2} \mathrm{O}$. The solubility of $\mathrm{ZnSO}_{4} \cdot 7 \mathrm{H}_{2} \mathrm{O}$ in water from 0 to $39{ }^{\circ} \mathrm{C}$ is given in table 4 . In saturated solution zinc sulfate hydrolyzes to give a solution containing $0.004 \mathrm{~N}$ sulfuric acid and having a $\mathrm{pH}$ of 3.35 at $25^{\circ} \mathrm{C}$ [73]. This concentration of acid is sufficient to prevent the hydrolysis of the mercurous sulfate used in the positive electrode (see later).

The emf of the Clark cell decreases as the temperature is increased; the decrease is about 0.1 percent per degree $\mathrm{C}$. For the range 0 to $28^{\circ} \mathrm{C}$ Callendar and Barnes [67] gave, in volts:

$$
E_{\ell}=E_{15^{\circ}}-0.0012\left(\ell-15^{\circ}\right)-0.0000062\left(\ell-15^{\circ}\right)^{2}
$$

for the dependence of the emf on temperature. At $15^{\circ} \mathrm{C}$ and $25^{\circ} \mathrm{C}$ this relation gives $-0.00120 \mathrm{~V} / \mathrm{deg} \mathrm{C}$ and $-0.001076 \mathrm{~V} / \mathrm{deg} \mathrm{C}$, respectively, for $d E / d t$. Kahle [74] and Jaeger and Kahle [75] who also studied the temperature dependence of Clark cells obtained results in substantial agreement with eq (6).

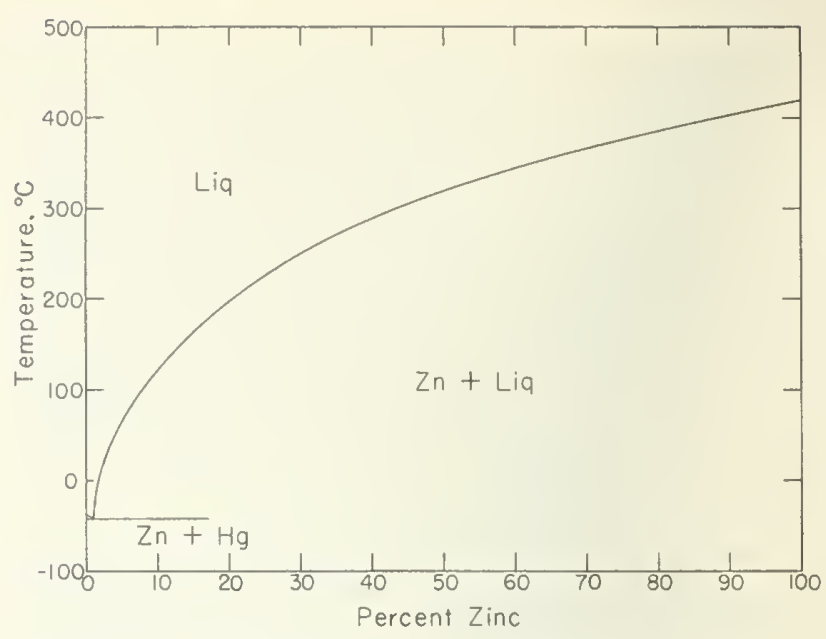

FIGURE 9. Phase diagram for the zinc-mercury system.

TABLE 3. Composition of the liquid phases of 10 percent zinc and cadmium amalgams

\begin{tabular}{c|c|c}
\hline \hline $\begin{array}{c}\text { Temperature, } \\
{ }^{\circ} \mathrm{C}\end{array}$ & $\begin{array}{c}\text { Percentage } \\
\text { of zinc }\end{array}$ & $\begin{array}{c}\text { Percentage } \\
\text { of cadmium }\end{array}$ \\
\hline & 1.35 & 2.50 \\
0 & 1.60 & 3.70 \\
10 & 1.99 & 5.00 \\
20 & 2.40 & 6.40 \\
30 & 2.90 & 7.80 \\
40 & & \\
\hline
\end{tabular}

TABLE 4. Solubility of $\mathrm{ZnSO}_{4} \cdot 7 \mathrm{H}_{2} \mathrm{O}$ in water

\begin{tabular}{c|c}
\hline \hline $\begin{array}{c}\text { Temperature } \\
{ }^{\circ} \mathrm{C}\end{array}$ & $\begin{array}{c}\mathrm{ZnSO}_{4} \text { in } \\
1000 \mathrm{~g} \mathrm{H}_{2} \mathrm{O},\end{array}$ \\
\hline & grams \\
& 419 \\
0 & 446 \\
5 & 477 \\
10 & 509 \\
15 & 542 \\
20 & 579 \\
25 & 620 \\
30 & 663 \\
35 & 701 \\
$39^{\circ}$ & \\
\hline
\end{tabular}

a-transition temperature, $\mathrm{ZnSO}_{4} \cdot 7 \mathrm{H}_{2} \mathrm{O}=\mathrm{ZnSO}_{4} \cdot 6 \mathrm{H}_{2} \mathrm{O}$.

The Clark cell has three advantages over the Weston cell, namely, (1) zinc sulfate hydrolyzes to produce sufficient sulfuric acid to prevent the hydrolysis of the mercurous sulfate paste; it, thereby supplies its own buffering action, (2) the solid phase of the amalgam is a single component (zinc) whereas in the Weston cell the solid phase is a solid solution of cadmium and mercury; the emf of the Clark cell is less dependent, therefore, on the composition of the amalgam than is the Weston cell, and (3) the Clark cell shows less emf-temperature hysteresis than the Weston cell. However, the disadvantages of the Clark cell over the Weston cell well outweigh its advantages. These are: (1) The Clark cell tends to gas at the amalgam electrode. This gas, as it forms slowly over the surface of the amalgam, may dislodge crystals of $\mathrm{ZnSO}_{4} \cdot 7 \mathrm{H}_{2} \mathrm{O}$ with adhering solution from over the amalgam, and may eventually cause an open-circuit in the electric circuit unless a 
constriction, as discussed later, is used in the container at the level of the crystals. (2) Zinc amalgam slowly alloys with the platinum lead at the base of the amalgam electrode. Since this alloy occupies more space than the platinum, strains are produced, and breakage of the glass container follows.

The Clark cell has an emf-temperature coefficient which is about 30 times that of the Weston cell. (4) Owing to the relatively large change in the solubility of zinc sulfate with changes in temperature crystals of $\mathrm{ZnSO}_{4} \cdot 7 \mathrm{H}_{2} \mathrm{O}$ tend to pass from the positive to the negative limb of the cell. During a temperature rise the volume of electrolyte over the positive electrode becomes saturated more quickly because it is usually a smaller volume than that over the negative electrode. As a result a concentration difference between the limbs results and diffusion of electrolyte to the negative limb takes place until the concentration difference is dissipated. This phenomenon can be prevented by making the volume above the negative and positive electrodes equal. A similar phenomenon does not occur in

\section{The Weston (or Cadmium Sulfate) Cell}

\subsection{General}

The Weston (or cadmium sulfate) cell is, for all intents and purposes, the only electrochemical system used today as a standard cell. Accordingly, the words "standard cell" when used today invariably mean cadmium sulfate cells, and the remainder of this Monograph, appendices excepted, relates to this type of cell. The cell is made in two general types, saturated and unsaturated where these terms refer to the state of the electrolyte. The saturated type is the precision cell used in the maintenance of the unit of emf. It may be made in a highly reproducible form and exhibits a constant emf for long periods of time. However, for high precision it must be maintained at a constant temperature owing to its relatively high emf-temperature coefficient. Most saturated cells must be hand carried, although some recent types have been made shippable by locking the electrodes in place with inert and porous septa. The unsaturated cell is less stable than the saturated type in that its emf decreases slowly with time and is regarded as a reference of $d \cdot c$ voltage known within \pm 0.005 percent. It is usually made in a shippable form with a septum over each electrode. It has a low emf-temperature coefficient and accordingly is used widely in ambient temperatures as an emf reference where 0.005 percent $(0.05 \mathrm{mV})$ accuracy suffices.

The saturated cell is also known as the Weston Normal Cell (or Element). It consists of a cadmium amalgam anode and a mercury-mercurous sulfate cathode in a saturated solution of cadmium sulfate with crystals of $\mathrm{CdSO}_{4} \cdot 8 / 3 \mathrm{H}_{2} \mathrm{O}$ over the surface of both electrodes. This cell may be represented by:

$(-) \mathrm{Cd}, \mathrm{Hg}(2 p)\left|\mathrm{CdSO}_{4} \cdot 8 / 3 \mathrm{H}_{2} \mathrm{O}(c)\right| \mathrm{CdSO}_{4}$ (sat aq) $\mid$

$\mathrm{CdSO}_{4} \cdot 8 / 3 \mathrm{H}_{2} \mathrm{O}(c)\left|\mathrm{Hg}_{2} \mathrm{SO}_{4}(s)\right| \mathrm{Hg}(l)(+)$
Weston cells because the change in solubility of cadmium sulfate with temperature is much less than that of zinc sulfate. (5) The Clark cell has an emf which is considerably higher than unity which, although not necessarily a disadvantage, makes its use as a standard less convenient than a Weston cell.

The emfs of saturated Clark cells are decreased by addition of sulfuric acid to the electrolyte. Some data based on measurements of Hulett [76] are given in table 5 .

TABLE 5. Effect of sulfuric acid on the emf of Clark cells at $25^{\circ} \mathrm{C}$

\begin{tabular}{c|c|c}
\multicolumn{2}{c|}{ Normality of sulfuric acid ${ }^{\alpha}$} & \multirow{2}{*}{ Change in emf. } \\
$\begin{array}{c}\text { Before saturation } \\
\text { with } \mathrm{ZnSO}_{4} \cdot 7 \mathrm{H}_{2} \mathrm{O}\end{array}$ & $\begin{array}{c}\text { After saturation } \\
\text { with } \mathrm{ZnSO}_{4} \cdot 7 \mathrm{H}_{2} \mathrm{O}\end{array}$ & \\
\hline 0.2024 & 0.1074 & volt \\
1.012 & 0.5400 & -0.00028 \\
2.024 & 1.1488 & -0.00233 \\
& 0.00448 \\
\hline
\end{tabular}

a - normality of acid in a saturated solution of pure zinc chloride at $25^{\circ} \mathrm{C}$ is 0.004 $V[73]$.

where the symbols have the same significance as given above. The cell reaction is:

$x \mathrm{Cd}, y \mathrm{Hg}(2 \mathrm{p})+\mathrm{Hg}_{2} \mathrm{SO}_{4}(s)+\frac{8 / 3}{m-8 / 3}\left(\mathrm{CdSO}_{4} \cdot m \mathrm{H}_{2} \mathrm{O}\right)($ sat aq $)$

$=\frac{m}{m-8 / 3}\left(\mathrm{CdSO}_{4} \cdot 8 / 3 \mathrm{H}_{2} \mathrm{O}(c)+2 \mathrm{Hg}(l)+(x-1) \mathrm{Cd}, y \mathrm{Hg}(2 \mathrm{p})\right.$.

where $x$ moles of $\mathrm{Cd}$ are associated with $y$ moles of $\mathrm{Hg}$ in the amalgam and $m$ is the number of moles of water associated with $\mathrm{I}$ mole of $\mathrm{CdSO}_{4}$ in the saturated solution. At the end of the reaction the amalgam may be two phases (liquid and solid) or may be a liquid phase only, depending on the extent of the reaction and the relative amounts of amalgam and mercurous sulfate used in preparing the cell. When not discharged, as is normal when the cell is used as an emf standard, the amalgam remains in two phases. Cells are usually made with 10 or $12^{1 / 2}$ percent amalgams (see later).

The unsaturated cell differs from the saturated type only in that an unsaturated solution of cadmium sulfate and no crystals of $\mathrm{CdSO}_{4} \cdot 8 / 3 \mathrm{H}_{2} \mathrm{O}$ are used. It is customary to use a solution that is saturated at 3 or $4{ }^{\circ} \mathrm{C}$, the temperature range at which the salt exhibits a minimum solubility; the solution is then unsaturated at higher temperatures. The emf of the unsaturated cell at ambient room temperature is about 0.05 percent higher than that of the saturated type. The cell reaction is simply:

$$
\begin{aligned}
x \mathrm{Cd}, y \mathrm{Hg}(2 p)+ & \mathrm{Hg}_{2} \mathrm{SO}_{4}(s)=\mathrm{CdSO}_{4}(\mathrm{aq}) \\
& +2 \mathrm{Hg}(l)+(x-1) \mathrm{Cd}, y \mathrm{Hg}(2 p)
\end{aligned}
$$

unless the reaction is continued until crystals of $\mathrm{CdSO}_{4} \cdot 8 / 3 \mathrm{H}_{2} \mathrm{O}$ are formed; then the reaction is the same as in the saturated cell. Again, when the cell is not discharged, as is normal when the cell is used as an emf standard, the solution remains unsaturated and the amalgam in two phases. 
Both saturated and unsaturated standard cells have been made as "neutral" or as "acid" cells; the saturated "neutral" type is also known as the Weston Normal Cell. These terms refer to the degree of acidity of the electrolyte with respect to sulfuric acid in the cell. If an aqueous solution of pure cadmium sulfate, to which no sulfuric acid is added, is used in the preparation of the cell, the cell is called a "neutral" type, even though the $p \mathrm{H}$ of a saturated aqueous solution of cadmium sulfate, owing to hydrolysis, is 4.00 at $25^{\circ} \mathrm{C}$ [73]. If sulfuric acid is added in sufficient amount to make the acidity 0.03 $N$ to $0.1 \mathrm{~N}$, the cell is called an "acid" type. The purpose of adding the acid to the electrolyte is to prevent hydrolysis of the mercurous sulfate used in the cell; more details are given later. Today, most, if not all, cells are made of the "acid" type.

\subsection{Preparation and Properties of Materials}

The procedures employed at the National Bureau of Standards for the preparation and purification of materials for use in the construction of standard cells are described in the next few sections. In addition some properties of the materials, as they relate to standard cells, are given. Only four materials are required. These are mercury, cadmium, sulfuric acid, and water, all of which may be purified by distillation. To these four materials may be added a fifth, $\mathrm{CdSO}_{4} \cdot 8 / 3 \mathrm{H}_{2} \mathrm{O}$, to avoid preparing it from cadmium and sulfuric acid; it may be purified by repeated crystallizations from conductivity water.

Mercury of good grade, after washing in dilute nitric acid, then in distilled water, is dried and then distilled in a Hulett [77] still in a stream of dry air. In this method, the mercury is distilled near $200{ }^{\circ} \mathrm{C}$ in a partial vacuum, air being drawn through the condenser at a rate to maintain the air pressure at $25 \mathrm{~mm}$, corresponding to an oxygen partial pressure of $5 \mathrm{~mm}$. Any metallic vapor, except mercury, is oxidized and collects as a scum on the distillate which is removed by filtering through a fine pinhole in filter paper. Metals more noble than mercury remain in the boiler of the still. Finally, the mercury is redistilled in a vacuum still. Procedures for purification of mercury of various grades are outlined in reference [78].

Cadmium of electrolytic grade is sublimed under reduced pressure. The sublimation is done at about 350 to $400{ }^{\circ} \mathrm{C}$ in an evacuated Pyrex glass tube with an external electrical heating jacket. The distilled cadmium crystallizes out on the cooler parts of the tube but frequently adheres tightly to the glass walls. It is usually necessary to break the glass walls to remove the distilled cadmium adhering to the walls.

Sulfuric acid of reagent grade is twice distilled in an all-Pyrex still at a temperature of 270 to $290^{\circ} \mathrm{C}$ with the middle fraction being retained. Glass beads are placed in the boiler to reduce bumping and the distillation is carried out in a hood.

Water is repeatedly distilled in a Barnstead or comparable still until the conductivity of the water becomes as low or lower than $1 \times 10^{-6} \mathrm{ohm}^{-1} \mathrm{~cm}^{-1}$. This water is frequently called "conductivity water."

Cadmium sulfate $\left(\mathrm{CdSO}_{4} \cdot 8 / 3 \mathrm{H}_{2} \mathrm{O}\right)$ of high grade is obtained by several recrystallizations of the C.P. salt. These recrystallizations are carried out from aqueous solutions below $43.6{ }^{\circ} \mathrm{C}$ [79] since above this temperature the stable salt is the monohydrate, $\mathrm{CdSO}_{4} \cdot \mathrm{H}_{2} \mathrm{O}$. Cadmium sulfate of high grade may also be prepared from pure cadmium and redis. tilled sulfuric acid solutions or from pure cadmium nitrate and redistilled sulfuric acid solutions, followed by recrystallizations of the salt from aqueous solutions in each case. The latter method is preferred rather than the use of very impure cadmium sulfate as starting material.

Both hydrates, $\mathrm{CdSO}_{4} \cdot 8 / 3 \mathrm{H}_{2} \mathrm{O}$ and $\mathrm{CdSO}_{4} \cdot \mathrm{H}_{2} \mathrm{O}$, are highly soluble in water; the solubility of the former increases with temperature while that of the latter decreases. The solubilities of each as a function of temperature are given in table $6[79,80$, 81]. The solubilities are expressed as the number of grams of the anhydrous salt in $1000 \mathrm{~g}$ of water.

Saturated solutions of $\mathrm{CdSO}_{4} \cdot 8 / 3 \mathrm{H}_{2} \mathrm{O}$ begin to freeze at $-17^{\circ} \mathrm{C}$ and become completely frozen at $-24{ }^{\circ} \mathrm{C}$; these temperatures, then, represent the lower limit for the use of cadmium sulfate cells (see later). It has been reported [82] that $\mathrm{CdSO}_{4} \cdot 8 / 3$ $\mathrm{H}_{2} \mathrm{O}$ shows a transition to $\mathrm{CdSO}_{4} \cdot 7 \mathrm{H}_{2} \mathrm{O}$ at $4{ }^{\circ} \mathrm{C}$. However, cells tested in this temperature range do not exhibit an abrupt inflection in emf at $4{ }^{\circ} \mathrm{C}$ indicative of a phase change but a smooth maximum in the range of 3 to $4{ }^{\circ} \mathrm{C}$ indicative of a minimum solubility in cadmium sulfate (see table 6).

The amalgam may be prepared either electrolytically by depositing cadmium in mercury or by heating the two metals together. In the former, crystals of purified $\mathrm{CdSO}_{4} \cdot 8 / 3 \mathrm{H}_{2} \mathrm{O}$ are placed on the surface of mercury (contained on the bottom of a beaker) and covered with distilled water acidified with a few drops of sulfuric acid. Mercury is made

TABLE 6. Solubility of $\mathrm{CdSO}_{4} \cdot 8 / 3 \mathrm{H}_{2} \mathrm{O}$ and $\mathrm{CdSO}_{4} \cdot \mathrm{H}_{2} \mathrm{O}$ in (given as grams of $\mathrm{CdSO}_{4}$ in 1000 grams of water)

\begin{tabular}{|c|c|c|}
\hline Temperature, & $\begin{array}{c}\mathrm{CdSO}_{4}-8 / 3 \\
\mathrm{H}_{2} \mathrm{O}\left(\text { as } \mathrm{CdSO} \mathrm{O}_{4}\right)\end{array}$ & $\begin{array}{l}\mathrm{CdSO}_{4} \cdot \mathrm{H}_{2} \mathrm{O} \\
\text { (as CdSO }\end{array}$ \\
\hline-18. & 767.6 & \\
\hline-15 & 765.3 & ............................ \\
\hline-10 & 762.1 & $\ldots \ldots \ldots \ldots+\ldots, \ldots, \ldots, \ldots$ \\
\hline-5 & $\begin{array}{l}759.2 \\
757.5\end{array}$ & 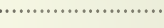 \\
\hline 0 & & 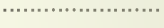 \\
\hline $\begin{array}{l}3 \\
5\end{array}$ & $\begin{array}{l}757.2 \\
757.5\end{array}$ & (1) \\
\hline 10 & 759.4 & (n) \\
\hline 15 & 761.4 & (1) \\
\hline 20 & 763.7 & ......................... \\
\hline 25 & 766.9 & (...................... \\
\hline 30 & 771.0 & 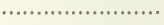 \\
\hline 35 & 776.5 & \\
\hline 40 & 783.8 & n...................... \\
\hline 42 & 787.2 & , $\ldots \ldots \ldots \ldots \ldots \ldots \ldots$ \\
\hline $\begin{array}{c}43.6^{a} \\
45\end{array}$ & $\begin{array}{l}790.5 \\
793.5\end{array}$ & 786.5 \\
\hline 50 & 806.1 & 770.6 \\
\hline 55 & ........... & 754.7 \\
\hline 60 & & 738.9 \\
\hline 65 & ..... & 722.0 \\
\hline 70 & & 707.0 \\
\hline 72 & . & 700.0 \\
\hline
\end{tabular}

${ }^{a}$-transition temperature. 
the cathode and a platinum foil suspended in the acidified solution at the top serves as anode. Usually only the amount of $\mathrm{CdSO}_{4} \cdot 8 / 3 \mathrm{H}_{2} \mathrm{O}$ needed to prepare an amalgam with the desired percentage of cadmium is used. Since the crystals dissolve slowly, a current of low magnitude is used initially until nearly all the cadmium is deposited. The current is then increased to about 5 times the initial value for 30 minutes, and then, with the current still flowing, washing with distilled water is started. Water is successively added and decanted until the current decreases to less than $0.01 \mathrm{~A}$ for an im. pressed voltage of $110 \mathrm{~V}$. The remaining water is then siphoned off and the last drops of water removed from the surface of the amalgam by filter paper. A cadmium rod may be used as anode in an alternative procedure; the amount of cadmium deposited in the mercury is determined from the current and time by Faraday's law.

The method in which the two metals are heated together is more convenient. The proper weights of the two metals are heated together in a covered porcelain casserole, in a hood, until completely melted and homogeneous. A slight scum may form on the surface. This is brushed aside and the liquid amalgam immediately transferred to an electrically heated covered buret and introduced directly to the cell through an electrically heated delivery tube. Any small amount of scum on the surface of the amalgam will disappear as soon as acidified cadmium sulfate is added to the cell. This is the method now used at the National Bureau of Standards.

No difference in the properties of standard cells containing amalgams prepared by these methods has been observed.

Amalgams exhibit less erratic behavior and corrode less rapidly, if at all, than pure unamalgamated metals when in contact with aqueous solutions of their salts. Amalgamation raises the hydrogen overvoltage of metals and reduces stresses within the metal. It is for these reasons that amalgams make better anodes for standard cells than the pure metals. A 10 or $12^{1 / 2}$ percent amalgam is generally used commercially in constructing cadmium sulfate cells. A 10 percent amalgam is now used by the National Bureau of Standards. These are weight percentages. At normal temperatures amalgams of these precentages consist of two phases, a liquid and a solid phase. The solid phase is a solid solution of cadmium and mercury. The phase diagram [83] for the cadmium-mercury system is given in figure 10 . The composition of the liquid phase of a 10 percent amalgam is listed for various temperatures in column 3 of table 3 .

Mercurous sulfate may be prepared in a number of ways. Shortly after Weston patented his cell much research was devoted to methods of preparing and storing mercurous sulfate and cells made with various preparations were extensively studied. Some samples were white, i.e., devoid of free mercury while others were gray in appearance owing to the presence of finely dispersed mercury. Some samples were thoroughly washed with absolute alcohol and anhydrous ether and dried in vacuo while other samples were kept moist with either dilute sulfuric acid or saturated solutions of cadmium sulfate acidified slightly with sulfuric acid.

Mercurous sulfate may be prepared in a number of ways as follows:

(1) By the reaction between sulfuric acid and mercurous nitrate [84].

(2) By the action of fuming sulfuric acid on mercury [84].

(3) By the action of dilute nitric acid in sulfuric acid on mercury $[44,84]$.

(4) By the reduction of mercuric sulfate by mercury [44].

(5) By the reduction of mercuric sulfate by sulfurous acid [44].

(6) By the reduction of mercuric sulfate by formaldehyde [85].

(7) By the recrystallization of commerical mercurous sulfate from sulfuric acid [84].

(8) By a-c electrolysis [86].

(9) By d-c electrolysis $[44,68]$.

Of these methods standardization has been on the last one which is now used by the National Bureau of Standards. By d.c electrolysis uniform samples of mercurous sulfate of high purity and reproducible grain size are obtained. Such samples are free of all foreign materials except sulfuric acid, water, and mercury, all of which are used in standard cells, and especially in the mercurous sulfate paste. In this method $[44,68]$ mercury anodes, platinum cathodes, and a 1:6 sulfuric acid-water solution are used and electrolysis is carried out in a darkened room (see sec. 7.7). Mercury is placed on the bottom of one or two shallow glass vessels. These vessels are then placed on a glass stand one above the other, as shown in figure 11 , in a deeper and larger dish $2 / 3$ filled with the sulfuric acid solution; the acid solution extends over the shallow vessels. The upper dish contains a central glass tube through which passes the shaft for the stirrer for the lower dish; obviously this is unnecessary if only one shallow dish were used. A platinum-foil cathode is placed near the top of the solution. The solution is vigorously stirred at 70 to $200 \mathrm{rpm}$ and

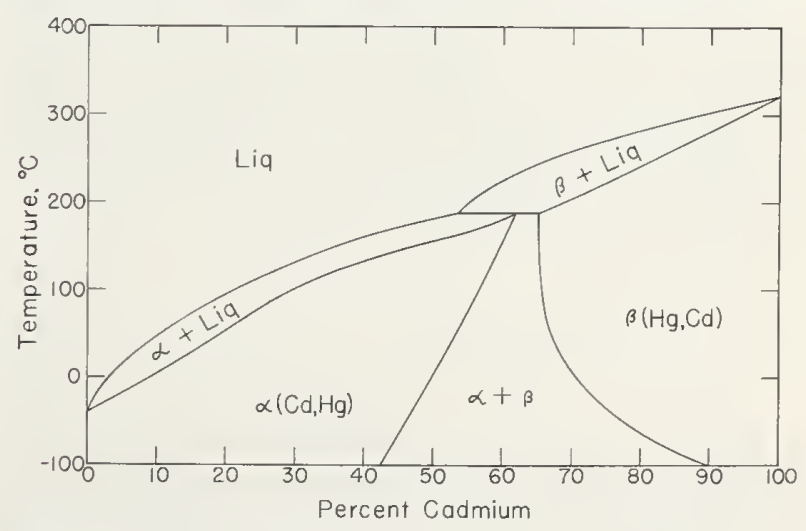

Figure 10. Phase diagram for the cadmium-mercury system. 


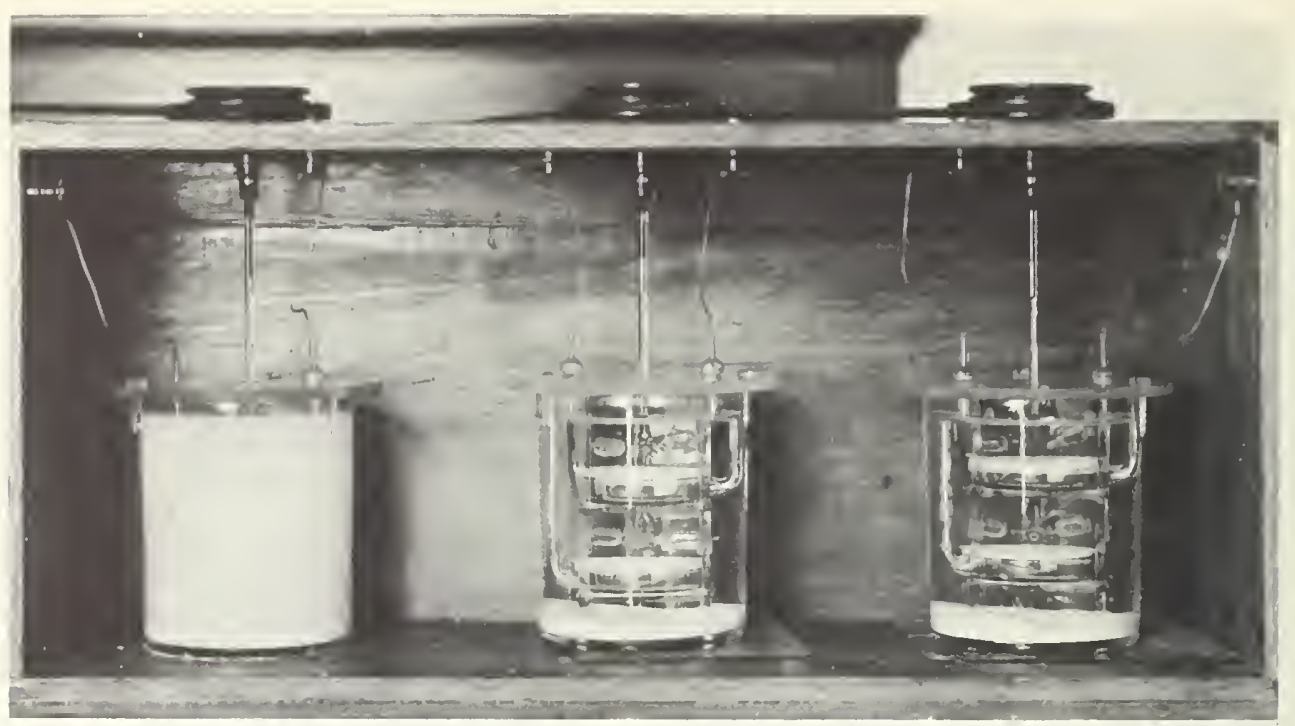

FIGURE 11. Views of the electrolytic preparation of mercurous sulfate.

Left vessel-stirrer in operation, cloudiness due to mercurous sulfate suspended in solution.

Center and right vessels-stirring stopped, mercurous sulfate at bottom of vessels and on surface of mercury in dishes.

the current density at the mercury surface is maintained at 1 to $2 \mathrm{~A}$ per $100 \mathrm{~cm}^{2}$. When the electrolyte becomes saturated with mercurous sulfate the solid salt appears on the surface of the mercury and must be swept off into the outer dish by stir. ring in order to keep the surface of the mercury anode clean. In this stirring finely divided mercury becomes mixed with the mercurous sulfate to give a gray product. Electrolysis is continued until the desired amount of gray mercurous sulfate has been prepared; the current is then cut off but stirring is continued for several hours. Photographs of the electrolytic production of mercurous sulfate are shown in figure 11.

For "neutral" cells the mercurous sulfate is then washed repeatedly with a saturated solution of cadmium sulfate and then stored under such a solution until used. For "acid" cells the mercurous sulfate is stored under the electrolysis solution until needed at which time it is washed thoroughly with the solution of the type to be used in the cells.

Mercurous sulfate is the oxidizing agent or the "depolarizer" used in Weston cells. It is highly insoluble in water and in dilute solutions of sulfuric acid. The solubility of mercurous sulfate, expressed in terms of mercury, in various concentrations of sulfuric acid is listed in table 7 at 0 and $28{ }^{\circ} \mathrm{C}$ [87]. In aqueous solutions mercurous sulfate hydrolyzes according to the reaction:

$$
\begin{aligned}
2 \mathrm{Hg}_{2} \mathrm{SO}_{4}(s)+\mathrm{H}_{2} \mathrm{O}(l)= & \mathrm{Hg}_{2} \mathrm{O} \cdot \mathrm{Hg}_{2} \mathrm{SO}_{4}(s) \\
& +\mathrm{H}_{2} \mathrm{SO}_{4}(\mathrm{aq})
\end{aligned}
$$

to form a basic salt, $\mathrm{Hg}_{2} \mathrm{O} \cdot \mathrm{Hg}_{2} \mathrm{SO}_{4}$, and an equilibrium amount of sulfuric acid. Gouy [88] and Hager and Hulett [89] found this concentration to be $0.002 N$ while Craig, Vinal, and Vinal [87] showed that it did not change appreciably with temperature, being $0.00198 \mathrm{~N}$ at $0{ }^{\circ} \mathrm{C}$ and $0.00216 N$ at $28{ }^{\circ} \mathrm{C}$. Although, theoretically, a concentration slightly exceeding the equilibrium concentration could be used to prevent the hydrolysis of mercurous sulfate, a higher concentration is recom. mended. In initial studies [90], solutions $0.03 \mathrm{~N}$ to $0.06 \mathrm{~N}$ with respect to sulfuric acid were used, in part because mercurous sulfate exhibits a minimum solubility in the range from 0.04 to $0.08 \mathrm{~N}$. (Hulett [91] and Sir Frank Smith [92] found the minimum solubility of mercurous sulfate to be at approximately $0.04 \mathrm{~N}$, while Craig, Vinal, and Vinal found it to be at $0.06 \mathrm{~N}$ at $28^{\circ} \mathrm{C}$ and $0.08 \mathrm{~N}$ at $0{ }^{\circ} \mathrm{C}$.) Now, the lower acidity value is preferred since cells with the lower acidity have shown the greater stability in emf. Cells with $0.10 \mathrm{~N}$ acid, for example, tend to gas as a result of the action of the acid with the cadmium amalgam.

Concentrations of sulfuric acid somewhat higher than the equilibrium value are chosen, not only because of the decrease in the solubility of merTABLE 7. Solubility of mercurous sulfate in aqueous solutions

\begin{tabular}{|c|c|c|c|c|c|}
\hline \multirow{2}{*}{$\begin{array}{l}\text { Molarity of } \\
\mathrm{H}_{2} \mathrm{SO}_{4}\end{array}$} & \multicolumn{2}{|c|}{ Grams of $\mathrm{Hg}$ per $100 \mathrm{ml}$} & \multirow{2}{*}{$\begin{array}{c}\text { Molarity of } \\
\mathrm{H}_{2} \mathrm{SO}_{4}\end{array}$} & \multicolumn{2}{|c|}{ Grams of $\mathrm{Hg}$ per $100 \mathrm{ml}$} \\
\hline & $\iota=0^{\circ} \mathrm{C}$ & $t=28^{\circ} \mathrm{C}$ & & $t=0^{\circ} \mathrm{C}$ & $\ell=28^{\circ} \mathrm{C}$ \\
\hline 0.002 & 0.0290 & 0.0463 & 0.100 & 0.0183 & 0.0344 \\
\hline .004 & .0239 & .0395 & .200 & .0198 & .0379 \\
\hline .006 & .0215 & .0360 & .300 & .0212 & .0403 \\
\hline .008 & .0203 & .0346 & .400 & .0224 & .0423 \\
\hline .010 & .0197 & .0338 & .500 & .0233 & .0438 \\
\hline .020 & .0182 & .0318 & .600 & .0239 & .0451 \\
\hline .030 & .0179 & .0313 & .700 & .0244 & .0461 \\
\hline .040 & .0178 & .0317 & .800 & .0247 & .0467 \\
\hline .050 & .0178 & .0322 & .900 & .0248 & .0470 \\
\hline .060 & .0178 & .0327 & 1.000 & .0249 & .0470 \\
\hline .070 & .0179 & .0332 & 2.000 & .0240 & .0409 \\
\hline .080 & .0180 & .0337 & 3.000 & .0139 & .0294 \\
\hline .090 & .0181 & .0341 & 4.000 & .0078 & .......... \\
\hline
\end{tabular}
of sulfuric acid 
curous sulfate but because the acid decreases the rate of solubility of the glass container by the electrolyte. It is well known that glasses are more soluble in neutral salt or alkaline solutions than in acidic ones [93, 94]]. The final solution is titrated against sodium hydroxide using methyl purple as an indicator, which has a $\mathrm{pH}$ transformation interval of 4.8 to 5.4 [ [95].

\subsection{Containers for Standard Cells}

Saturated standard cells as made at the National Bureau of Standards are of the H-form shown in figure 12. Photographs of a cell container and a completed cell constitute figure 13 . The container is made of Kimble Standard Flint glass, a chemically resistant soda-lime glass, having an average linear thermal expansion coefficient of $92 \times 10^{-7}$ per degree C. (The coefficient of linear thermal expansion is the increase in length per unit length, measured at $0{ }^{\circ} \mathrm{C}$, per degree Celsius.) Since this linear thermal expansion coefficient approximates that of platinum, $89 \times 10^{-7}$ per degree C, vacuumtight seals are obtained at the platinum leads. No lead-containing sealing-in glass is used in sealing in the platinum leads at the bottom of each limb as the solution may extract the lead leading to cell deterioration. On the average the height of the cell is about $92 \mathrm{~mm}$, the diameter of the vertical limbs about $16 \mathrm{~mm}$, the diameter of the crossarm about $11 \mathrm{~mm}$, and the distance between limbs about $22 \mathrm{~mm}$. A constriction is made near the base of both limbs, as shown, to lock in part of the crystals of $\mathrm{CdSO}_{4} \cdot 8 / 3 \mathrm{H}_{2} \mathrm{O}$. The constriction may be a complete circumferential indentation or may consist of several knobs directed inward. The constrictions are so placed that crystals of $\mathrm{CdSO}_{4} \cdot 8 / 3 \mathrm{H}_{2} \mathrm{O}$ are both below and above them. These locked crystals prevent the displacement of the materials in the cell limbs, and those at the anode help prevent an opening of the circuit within the cell by any gas that might form on the amalgam. The platinum leads are secured by cotton thread to the side of each limb at the constrictions and cemented in place by collodion; platinum leads have a tendency to break mechanically at the glass seal if not securely held in place. For permanent records a number is etched on each cell on the outside wall of the container with hydrofluoric acid. Prior to filling with cell constituents the container is thoroughly cleaned with nitric acid, rinsed with distilled water, steamed, and then dried at $110^{\circ} \mathrm{C}$.

At various times attempts have been made to use Pyrex for cell containers. However, since Pyrex has an average linear thermal expansion coefficient of $32 \times 10^{-7}$ per degree $C$ tungsten which has a linear thermal expansion coefficient of $43 \times 10^{-7}$ per degree $\mathrm{C}$ must be used for external electrical connections to assure vacuum-tight seals. Tungsten, however, is more brittle than platinum and a number of cells have had to be discarded because of breaks at the tungsten-Pyrex seal.

Fused silica, owing to its extreme inertness, has frequently been suggested for standard-cell con-

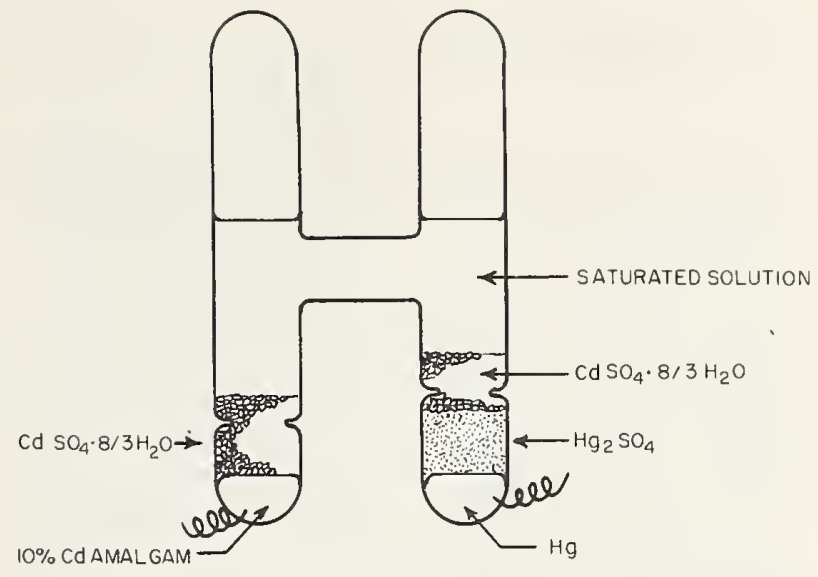

FigurE 12. Sketch of a saturated standard cell of the cadmium sulfate type (National Bureau of Standards type).

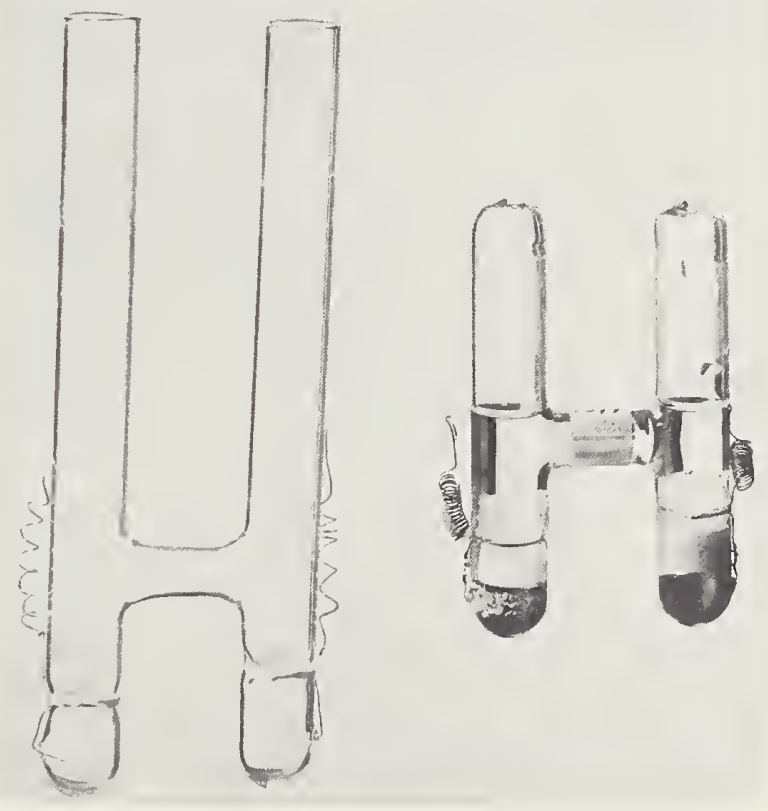

FIGURE 13. Photograph of container and completed saturated standard cell of cadmium sulfate type (National Bureau of Standards types).

tainers. Fused silica, however, has two major drawbacks. It has such a low linear thermal expansion coefficient $\left(5 \times 10^{-7}\right.$ per degree $\left.C\right)$ that the electrical leads have to be brought into the cell in a special way. Also, a very high temperature must be employed to seal the cell; the chemicals within the cell may thereby be affected. These two drawbacks have been solved by the cell design [96] shown in figure 14. The main features of this design are (1) the use of two seals at each arm and (2) a graded seal between the fused silica and Pyrex at the top of each limb of the container. The use of the graded seals makes possible the sealing of the cell at a low temperature after filling. Transparent silica is used to facilitate the filling of the cells. The two seals at each arm are spaced about $7 \mathrm{~cm}$ 


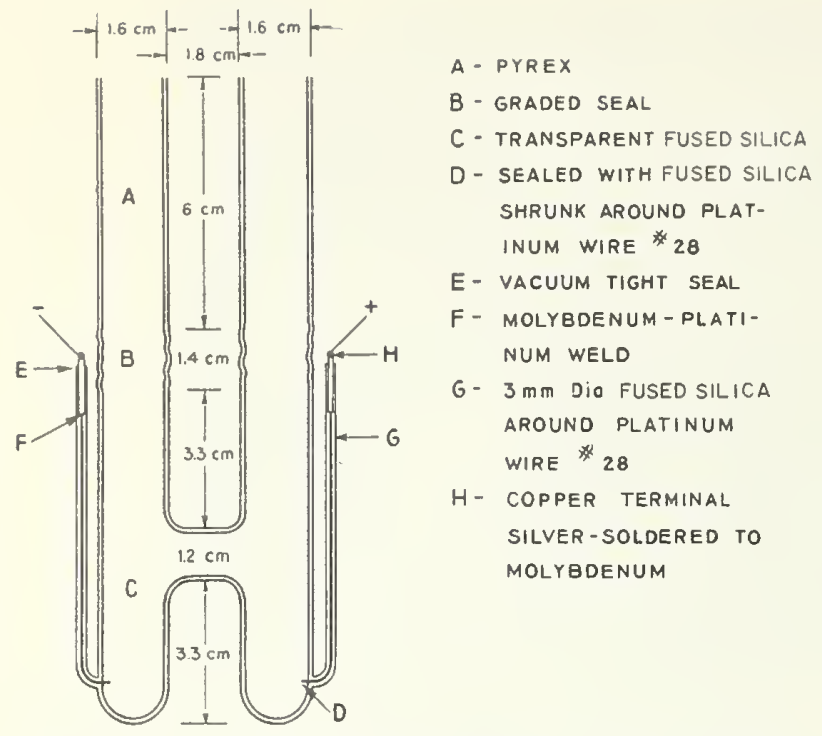

Figure 14. Cross-sectional sketch of standard-cell container made of fused silica.

apart. The lower seal consists of platinum wire No. 28 sealed in silica, and although this seal is not vacuum-tight it is sufficiently tight to retain the cell constituents. The upper vacuum-tight seal is a Houskeeper [97] type and consists of molybdenum ribbon sealed in silica (this type of seal cannot be used as the lower seal since molybdenum is chemically attacked by the cell constituents). The molybdenum ribbon and platinum wire are welded at a point about $2 \mathrm{~cm}$ below the upper seal. Silica is shrunk around the weld, the molybdenum ribbon, and platinum wire. Copper terminals are used and are silver-soldered to the molybdenum ribbon. Errors that might arise from thermoelectric effects are prevented by completely immersing the cells in oil at a constant temperature. Dimensions of the cell are included with the figure.

Although it has been generally thought that interactions between the glass container and the cell electrolyte cause "aging" or drifts in the emf of standard cells, available data have not shown significant differences between cells made in soft glass, Pyrex, or fused silica on a long-term basis. Plastic containers have also been proposed [98]. These must prevent vapor transport or a drying out of the cells may occur.

\subsection{Assembly and Mounting of Standard Cells}

Two long-stemmed funnels, one sliding through the other, are employed at the National Bureau of Standards for introducing materials into the container. The inner funnel carries the material and the outer one serves to prevent the material from coming into contact and "mussing up" the walls of the container. After introducing the material the stem of the inner funnel is drawn up into the stem of the outer funnel; both funnels may then be withdrawn from the cell without any of the material touching the container walls.

Mercury is first placed in the bottom of one limb and the amalgam in the bottom of the other limb, each to a depth of about $6 \mathrm{~mm}$. The amalgam is added while warm and in a single liquid phase; on cooling the amalgam becomes two-phased, solid and liquid. The mercurous sulfate is then placed in a Gooch or similar crucible, washed free of the solution under which it was stored with dilute sulfuric acid and then washed with solution of the type to be used in the cell, and then while moist introduced over the mercury to a depth of about 13 $\mathrm{mm}$. The mercurous sulfate should be mixed with a small amount of mercury (partially done during the electrolytic preparation of mercurous sulfate) and finely divided crystals (fineness of granulated sugar) of $\mathrm{CdSO}_{4} \cdot 8 / 3 \mathrm{H}_{2} \mathrm{O}$ prior to introduction to the cell; this mixing may be done prior to the washing procedure. The mixing and washing of the mercurous sulfate paste hastens the attainment of chemical equilibrium within the cell after its assembly.

Crystals of $\mathrm{CdSO}_{4} \cdot 8 / 3 \mathrm{H}_{2} \mathrm{O}$, of a size that will pass through a tube of $4-\mathrm{mm}$ bore, are then added to both limbs of the cell to a depth of about $10 \mathrm{~mm}$ at the negative electrode and about $8 \mathrm{~mm}$ at the positive electrode. Finally, a saturated solution of $\mathrm{CdSO}_{4} \cdot 8 / 3 \mathrm{H}_{2} \mathrm{O}$ is added to a level slightly above the crossarm, and the cell is then hermetically sealed.

In some cells, especially of larger size, large crystals (about 10 to $15 \mathrm{~mm}$ in diameter) of $\mathrm{CdSO}_{4}$. $8 / 3 \mathrm{H}_{2} \mathrm{O}$ are used. Larger crystals have an advan. tage over smaller crystals in that any gas that may form at the electrode surface (especially the negative one) will not become entrapped by the crystals whereby an open circuit might be produced. However, cells with large crystals tend to come to equilibrium, after a temperature change, more slowly than those made with small crystals.

Unsaturated cells are made similarly except that no crystals of $\mathrm{CdSO}_{4} \cdot 8 / 3 \mathrm{H}_{2} \mathrm{O}$ are used and they are made portable (shippable) by inserting cork or plastic rings, covered with linen, over the electrode surfaces. In some cells ceramic discs, either locked in place or supported by ceramic rod which protrudes through stoppers in each limb, are used $[99,100]$. The unsaturated cell is the commercial type used widely in the United States for work requiring no greater accuracy than \pm 0.005 percent; it is not made at the National Bureau of Standards. It is used for pyrometer work, in $\mathrm{pH}$ meters, recording instruments, etc., and is usually housed in nontransparent copper-shielded cases for general laboratory work. A copper-shielded case is employed to assure a uniform temperature at both limbs of the cell (see later). Saturated cells are not mounted in cases since they are intended for immersion in temperature-controlled oil or air baths. Commercial saturated cells are usually mounted in groups of 3,4 , or 6 on special racks 
for convenience in use. NBS saturated cells are mounted in oil as described above in section 2.3.

In practice, saturated standard cells are maintained at a constant temperature in thermostatically controlled oil baths or in portable thermostatically controlled air boxes. The latter are generally made after a design first proposed by Mueller and Stimson [101]. The cells are housed in a thin-walled aluminum box which rests in a larger thick-walled aluminum box, the temperature of which is controlled by a mercury-in-glass thermoregulator. The aluminum boxes are thermally insulated and are enclosed in a wooden box which also contains an a-c relay, a transformer, and a pilot light. The box is operated on $110 \mathrm{~V} 60$-cycle a-c line. The leads from the individual cells are brought to binding posts on the outside of the box. These boxes are designed to operate at temperatures above room temperature; the choice of temperature depends on the location where the boxes will be used or on the size of the box. As a rule these boxes operate at some temperature between 28 and $37^{\circ} \mathrm{C}$. The temperature of the cells in the air box is measured by a mercury-in-glass thermometer provided with the box. In some boxes, a well is added to provide for a platinumresistance thermometer in which case the temperature is so measured. A detailed description of a Mueller-Stimson box is given in Appendix 7.

\subsection{Electromotive Forces of Newly Made Cells}

Cells when first made will, except in the most rare cases, exhibit emfs that will differ considerably from the final steady values. Values steady to $0.01 \mathrm{mV}$ or $10 \mu \mathrm{V}$ are usually obtained within a few days but one to three years may be required before values steady to $0.1 \mu \mathrm{V}$ are attained. In some cases the emfs decline in their approach to equilibrium, in other cases they increase. There are two main reasons for this "aging" process, namely, (1) equalization of acid throughout the cell and especially within the mercurous sulfate paste, and (2) attainment of solution saturation. Although attempts are made to take care of both of these during cell assembly, inequalities in acid concentration may readily occur during the filling process owing to evaporation; and since the preparation of solutions of cadmium sulfate which are truly saturated is an extremely slow process unsaturated solutions may inevitably be used in preparing cells. Cells that "age" with a decrease in emf probably have been made with unsaturated solutions, even though crystals of $\mathrm{CdSO} \mathrm{O}_{4} \cdot 8 / 3 \mathrm{H}_{2} \mathrm{O}$ are present, or have too much acid in the negative limb while those that increase in emf during "aging" probably have excess acid in the positive limb. Also, the reaction between the electrolyte and the glass container probably contributes to "aging" since as the glass neutralizes some of the acid in the cell the emf will increase. However, this reaction eventually ceases as is shown by the emf stability of cells which have been "aged" (see later). If reproducibility of 0.01 $\mathrm{mV}$ in emf is considered adequate, all of these factors are inconsequential.

Cells within any one group, although made at the same time of the same materials, may have emfs that differ by as much as $0.005 \mathrm{mV}$ (or $5 \mu \mathrm{V}$ ). These differences may not only be present initially but may persist for years; i.e., individual cells, although differing in emf may show high stability in emf. Although diffusion is a slow process, acid ò solution concentration inequalities within any one cell cannot explain these differences. Instead they must arise (1) from slight differences in the composition of the amalgam between cells (see fig. 15, especially the horizontal sections; this figure is discussed in sec. 6.3) even though precautions are taken to keep the amalgam homogeneous during the filling process, (2) from slight differences in the acidity of the solutions between cells produced during the filling process or in interactions with the glass containers, and/or (3) to slight differences between cells in the grain size of the mercurous sulfate used in the positive electrodes.

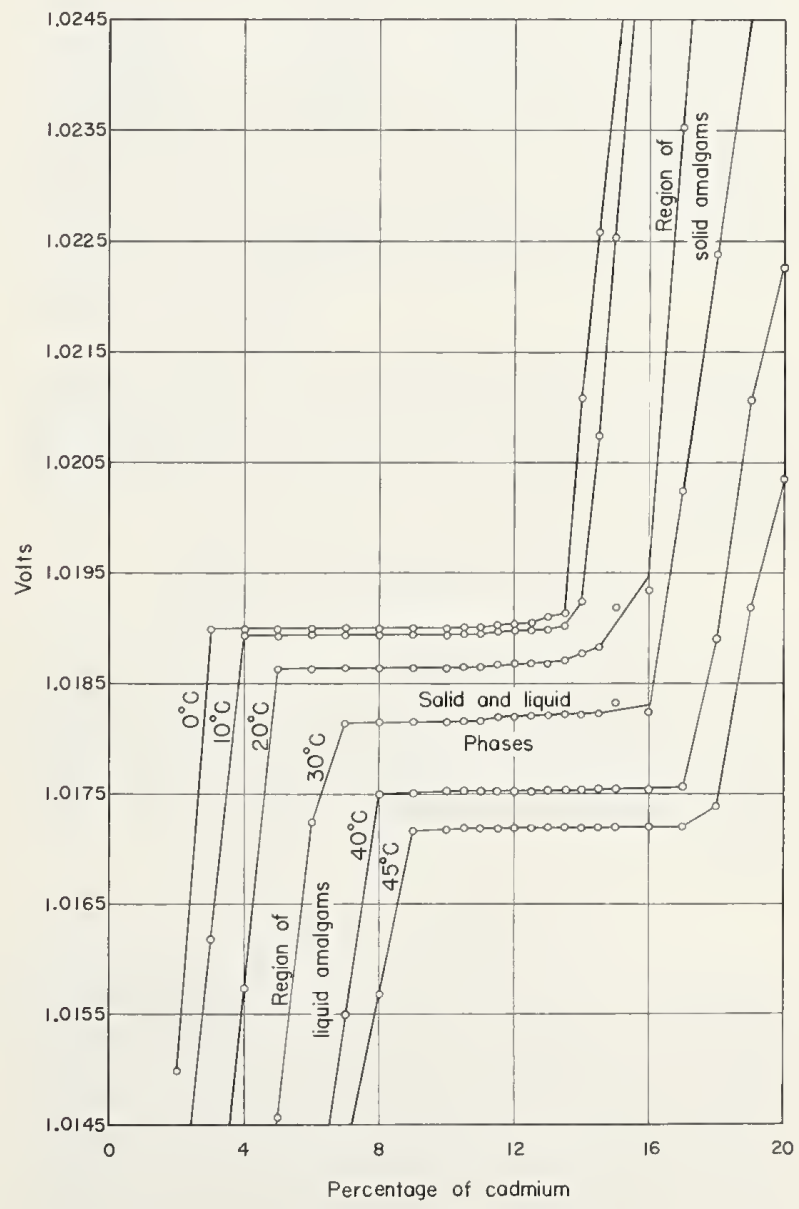

Figure 15. Relation of the electromotive force of the cadmium sulfate standard cell to the percentage of cadmium in the amalgam and the temperature. 


\section{Effect of Variations in Components on the Electromotive Force of Standard Cells}

\subsection{Concentration of Solution}

The emf of cadmium sulfate cells depends on the concentration of the cadmium sulfate solution. Over a limited range of concentration near saturation the emf increases about $0.0017 \mathrm{~V}$ for a one percent decrease in cadmium sulfate content. For more dilute solutions the change is somewhat greater. In table 8 the emfs at $25^{\circ} \mathrm{C}$ corresponding to various concentrations of cadmium sulfate, near saturation, are given. These data are based on results of Vosburgh and Eppley [102] for cells containing $12 \frac{1 / 2}{2}$ percent amalgams and $0.023 \mathrm{~N} \mathrm{H}_{2} \mathrm{SO}_{4}$; their data reported in international volts have been converted to absolute volts here. For neutral solutions the emfs listed here would be $18 \mu \mathrm{V}$ higher.

TABLE 8. Electromotive forces of cadmium sulfate cells at $25^{\circ} \mathrm{C}$ as a function of electrolyte concentration

\begin{tabular}{c|c|c|c}
\hline \hline CdSO. & Emf & CdSO, & Emf \\
\hline & $V$ & percent & $V$ \\
41.84 & 1.021289 & 42.98 & 1.018990 \\
42.39 & 1.020019 & 43.06 & 1.018883 \\
42.63 & 1.019673 & 43.12 & 1.018704 \\
42.77 & 1.019315 & 43.22 & 1.018603 \\
42.90 & 1.019121 & $43.402{ }^{\circ}$ & $1.018392^{\circ}$ \\
42.94 & 1.019043 & & \\
\hline
\end{tabular}

- saturated solution.

\subsection{Acidity of Solution}

The addition of sulfuric acid slightly decreases the emf of a cadmium sulfate cell. For the saturated cell several equations have been proposed relating the change in emf to acid concentration. For acid concentrations up to $4 N$ Sir Frank Smith [103] gave:

$$
\Delta E(\text { volts })=-\left(0.00060 x+0.00005 x^{2}\right)
$$

where $\Delta E$ is the difference in emf of acid cells from neutral ones and $x$ is the normality of the sulfuric acid solution before it is saturated with $\mathrm{CdSO}_{4} \cdot 8 / 3$ $\mathrm{H}_{2} \mathrm{O}$. For acid concentrations up to $0.4 \mathrm{~N}$ only, the National Physical Laboratory [104] gave the linear relation

$$
\Delta E(\text { microvolts })=-615 x \text {. }
$$

Obata [105] and Ishibashi and Ishizaki [106] also gave linear relations with the coefficients being, respectively, -855 and -833 ; Vosburgh [107] found Obata's equation to be valid to $1.49 N$. In these last two, $x$ refers to the normality of the acid in a saturated solution of $\mathrm{CdSO}_{4} \cdot 8 / 3 \mathrm{H}_{2} \mathrm{O}$. All of these formulas agree closely if applied properly. For low acidities, the acidity of a solution of sulfuric acid after saturation with $\mathrm{CdSO}_{4} \cdot 8 / 3 \mathrm{H}_{2} \mathrm{O}$ is 0.767 of that before saturation.
Differences between the emf of "neutral" and "acid" cells according to the Smith formula are listed in table 9. Sir Frank Smith [103] also investigated the effect on the emf of cadmium sulfate cells if the acid were confined to one or the other of the electrode compartments. For these effects, valid to $4 N$, he gave:

$$
\begin{aligned}
& \Delta E_{\text {negative }}(\text { volts })=0.01090 x-0.00125 x^{2} \\
& \Delta E_{\text {positive }}(\text { volts })=-0.01150 x+0.00120 x^{2}
\end{aligned}
$$

the summation of which gives the Smith equation above for the effect of acid on the emf of the cell as a whole. These differences for various normalities of acid are given in table 10 . These relations show that more acid at the negative electrode increases the emf while more acid at the positive electrode produces a decrease in emf. It is necessary, then, for high reproducibility and stability in emf that the acidity be the same and remain the same at the two electrodes.

TABLE 9. Differences of emf of "acid" cells from the standard value of Weston "neutral" cells

\begin{tabular}{c|c|c|c}
\hline \hline $\begin{array}{c}\text { Normality of } \\
\mathrm{H}_{2} \mathrm{SO} .\end{array}$ & $\begin{array}{c}\text { Difference of } \\
\text { emf }\end{array}$ & $\begin{array}{c}\text { Normality of } \\
\mathrm{H}_{2} \mathrm{SO}\end{array}$ & $\begin{array}{c}\text { Difference of } \\
\text { emf }\end{array}$ \\
\cline { 2 - 3 } & $\mu V$ & & $\mu V$ \\
0.01 & -6 & 0.30 & -185 \\
.02 & -12 & .40 & -248 \\
.03 & -18 & .50 & -312 \\
.04 & -24 & .60 & -378 \\
.05 & -30 & .70 & -444 \\
.06 & -36 & .80 & -512 \\
.07 & -42 & 1.00 & -580 \\
.08 & -48 & 2.00 & -650 \\
.09 & -54 & 3.00 & -1400 \\
.10 & -60 & 4.00 & -2250 \\
.20 & -122 & & -3200 \\
\hline
\end{tabular}

TABLE 10. Differences of emf of cells from the standard value of Weston "neutral" cells if the acid is confined to the negative or positive limb of cell

\begin{tabular}{c|c|c} 
& \multicolumn{2}{|c}{ Differences of emf, microvolts } \\
$\begin{array}{c}\text { Normality of } \\
\mathrm{H}_{2} \mathrm{SO}\end{array}$ & Negative limb & Positive limb \\
\cline { 2 - 3 } & & \\
\hline & & -115 \\
.01 & +109 & -230 \\
.02 & +218 & -344 \\
.04 & +434 & -458 \\
.05 & +542 & -572 \\
.06 & +650 & -686 \\
.07 & +757 & -799 \\
.08 & +864 & -912 \\
.09 & +971 & -1025 \\
.10 & +1078 & -1138 \\
.0 & +2130 & -2252 \\
.30 & +3157 & -3342 \\
.40 & +4160 & -4408 \\
.50 & +5138 & -5450 \\
.60 & +6090 & -6468 \\
.70 & +7018 & -7462 \\
.80 & +7920 & -8432 \\
.90 & +8798 & -9378 \\
1.00 & +9650 & -10300 \\
2.00 & +16800 & -18200 \\
3.00 & +21450 & -23700 \\
4.00 & +23600 & -26800 \\
& & \\
& &
\end{tabular}




\subsection{Composition of the Amalgam}

The emf of cadmium sulfate cells depends on the composition of the amalgam as may be seen by the data (converted to absolute volts) of Sir Frank Smith [108] and shown plotted in figure 15. This figure clearly shows that the useful range of amalgam composition is from about 8 to 14 percent cadmium for normal temperatures. The useful range of amalgam composition for standard cells is limited to the horizontal part of the curves; here the emf is very insensitive to or not critically dependent on the exact percentage of cadmium in the amalgam. In this range the amalgam consists of two phases, solid and liquid, with the solid phase being a solid solution of mercury and cadmium. For low and high percentages of cadmium the emf is very sensitive to the exact amount of cadmium in the amalgam; this sensitivity is more marked at lower temperatures. In figure 16 is shown the range over which amalgams of various cadmium content may be safely used. The range for use for a $12 \frac{1}{2}$ percent amalgam is about 12 to $62^{\circ} \mathrm{C}$ while for a 10 percent amalgam the range is from about -8 to $51{ }^{\circ} \mathrm{C}$. It is for this reason that a 10 percent amalgam is used in cells made at the National Bureau of Standards. The significances of the lower dotted lines $A$ and $B$ appearing in figure 16 were discussed under the section on cadmium sulfate; the significance of the upper dotted line is discussed in the next section.

\subsection{Crystal Phases of Cadmium Sulfate}

As was stated above, cadmium sulfate over a normal temperature range exists in two different hydrates, $\mathrm{CdSO}_{4} \cdot 8 / 3 \mathrm{H}_{2} \mathrm{O}$ and $\mathrm{CdSO}_{4} \cdot \mathrm{H}_{2} \mathrm{O}$ with the transition temperature being $43.6{ }^{\circ} \mathrm{C}$, below which the former hydrate is the stable form. The emfs of saturated standard cells made with these two different hydrates differ except at the transition point where the emfs are the same. Cells can be used in the metastable range for short periods of time. In either case, at a particular temperature, cells made with the more stable hydrate have the higher emf. These facts are illustrated by the data [109] given in table 11. These cells were "neutral" cells made with 10 percent amalgams. When a cell made with a particular hydrate is carried over into the metastable range its emf will correspond at first to that for a supersaturated solution of the metastable hydrate and then slowly rise in value as the

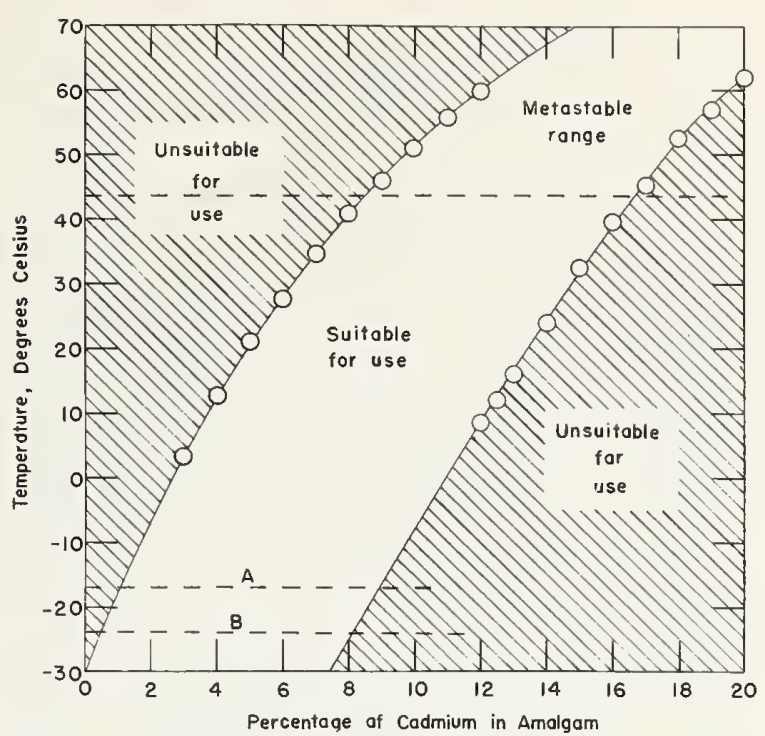

FIGURE 16. Range of temperature over which cadmium amalgams of various cadmium content may be used in standard cells.

hydrate is converted to the more stable form. This transition in phase is slow unless the two hydrates are present; then the transition is relatively fast. Accordingly, overheating of normal cells may have only transient adverse effects if the overheating is only momentary; otherwise the adverse effects may persist for long periods of time. In any case normal type saturated cells made with crystals of $\mathrm{CdSO}_{4} \cdot 8 / 3$ $\mathrm{H}_{2} \mathrm{O}$ should not be heated above $43.6{ }^{\circ} \mathrm{C}$; the upper dotted line in figure 16 corresponds to this upper temperature limit.

TABLE 11. The emfs of Weston Normal Cells made with crystals of $\mathrm{CdSO}_{4} \cdot 8 / 3 \mathrm{H}_{2} \mathrm{O}$ or crystals of $\mathrm{CdSO}_{4} \cdot \mathrm{H}_{2} \mathrm{O}^{*}$

\begin{tabular}{c|c|c}
\hline Temperature & $\begin{array}{c}\text { CdSO } \cdot 8 / 3 \mathrm{H}_{2} \mathrm{O} \\
\text { cells }\end{array}$ & $\begin{array}{c}\mathrm{CdSO}_{4} \cdot \mathrm{H}_{2} \mathrm{O} \\
\text { cells }\end{array}$ \\
\hline${ }^{\circ} \mathrm{C}$ & voles & volts \\
20 & 1.01866 & 1.01333 \\
25 & 1.01844 & 1.01417 \\
30 & 1.01817 & 1.01501 \\
35 & 1.01785 & 1.01587 \\
40 & 1.01752 & 1.01672 \\
$43.4^{* *}$ & 1.01729 & 1.01729 \\
45 & 1.01716 & 1.01757 \\
50 & 1.01682 & 1.01842 \\
\hline
\end{tabular}

\footnotetext{
*Original data of ref. [109] were in international volts; are converted here to absolute volts.

${ }^{* *} \mathrm{~A}$ better value for the transition temperature is $43.6^{\circ} \mathrm{C}[79]$
}

\section{Characteristics of Standard Cells}

\subsection{Emf-Temperature Coefficient}

Unsaturated standard cells have a very low emftemperature coefficient. Although it is frequently stated that unsaturated standard cells have a $d E / d t$ of $-0.00001 \mathrm{~V} / \mathrm{deg} \mathrm{C}$, the emf-temperature coeffi. cient is a function of temperature, is dependent on the concentration of the electrolyte, and increases as the cell ages. In table 12 , values of $d E / d t$ are given for temperatures from $15^{\circ} \mathrm{C}$ to $45^{\circ} \mathrm{C}$ for various weight percents of $\mathrm{CdSO}_{4}$. The emf values corresponding to cells made with the various concentrations of $\mathrm{CdSO}_{4}$ are given at $25^{\circ} \mathrm{C}$ as an aid to users in determining the emf-temperature coefficient of a particular cell. For example, if a cell had at $25^{\circ} \mathrm{C}$ an emf of $1.019043 \mathrm{~V}$ its $d E / d t$ would be 
TABLE 12. Emf-temperature coefficients of unsaturated standard cells

(In microvolts per degree Celsius)

\begin{tabular}{|c|c|c|c|c|c|c|c|c|}
\hline \multirow{2}{*}{$\mathrm{CdSO}_{4}$} & \multirow{2}{*}{ Emf, $25^{\circ} \mathrm{C}$} & \multicolumn{7}{|c|}{$d E / d t$} \\
\hline & & $15^{\circ} \mathrm{C}$ & $20^{\circ} \mathrm{C}$ & $25{ }^{\circ} \mathrm{C}$ & $30^{\circ} \mathrm{C}$ & $35^{\circ} \mathrm{C}$ & $40^{\circ} \mathrm{C}$ & $45^{\circ} \mathrm{C}$ \\
\hline$w t \%$ & volts & & & & & & & \\
\hline 41.84 & 1.021289 & -12.0 & -13.2 & -13.5 & -12.9 & -11.5 & -9.2 & -6.1 \\
\hline 42.39 & 1.020019 & -3.7 & -5.3 & -6.0 & -5.7 & -4.4 & -2.2 & +1.0 \\
\hline 42.63 & 1.019673 & -1.2 & -3.0 & -3.8 & -3.6 & -2.5 & -0.4 & +2.7 \\
\hline 42.77 & 1.019315 & +0.2 & -1.3 & -2.0 & -1.6 & -0.2 & +2.2 & +5.6 \\
\hline 42.90 & 1.019121 & +1.6 & -0.1 & -0.7 & -0.4 & +1.0 & +3.5 & +6.9 \\
\hline 42.94 & 1.019043 & +1.9 & +0.3 & -0.4 & 0 & +1.3 & +3.8 & +7.3 \\
\hline a 42.98 & 1.018990 & +2.3 & +0.6 & 0 & +0.1 & +1.7 & +4.2 & +7.6 \\
\hline 43.06 & 1.018883 & +3.2 & +1.5 & +0.8 & $\overline{+0.9}$ & $\overline{+2.5}$ & $\overline{+4.9}$ & $\overline{+8.4}$ \\
\hline 43.12 & 1.018704 & $b+3.8$ & +2.0 & +1.3 & +1.6 & +3.0 & +5.5 & +8.9 \\
\hline 43.22 & 1.018603 & ${ }^{b}+4.8$ & +2.9 & +2.2 & +2.5 & +3.9 & +6.4 & +9.9 \\
\hline c 43.402 & d 1.018392 & -30.4 & -40.6 & -49.4 & -56.6 & -62.4 & -66.6 & -69.4 \\
\hline
\end{tabular}

a - this composition corresponds to a solution saturated at $4{ }^{\circ} \mathrm{C}$ and gives a cell with a $d E / d t$ of zero at $25^{\circ} \mathrm{C}$.

-supersaturated.

c - percentage of $\mathrm{CdSO}_{4}$ in a saturated solution at $25{ }^{\circ} \mathrm{C} ; d E / d t$ values given are for solutions saturated with $\mathrm{CdSO}_{4} \cdot 8 / 3 \mathrm{H}_{2} \mathrm{O}$ at the respective temperatures.

d-contains $0.03 \mathrm{~N}_{2} \mathrm{SO}_{4}$

$-0.4 \mu \mathrm{V} / \operatorname{deg} \mathrm{C}$ at $25^{\circ} \mathrm{C}$, while if it had an emf of $1.018704 \mathrm{~V}$ its $d E / d t$ would be $+1.3 \mu \mathrm{V} / \mathrm{deg} \mathrm{C}$. Inspection of the data of table 12 also shows that a cell made with a solution containing 42.98 wt percent of $\mathrm{CdSO}_{4}$ has a zero emf-temperature coefficient at $25{ }^{\circ} \mathrm{C}$. Vosburgh and Eppley [102] showed that this percentage corresponds closely to a solution saturated at $4{ }^{\circ} \mathrm{C}$ (the solutions of Vosburgh and Eppley also contained $\left.0.023 \mathrm{~N} \mathrm{H}_{2} \mathrm{SO}_{4}\right)$. Since a solution saturated in the range from $3{ }^{\circ} \mathrm{C}$ to $4{ }^{\circ} \mathrm{C}$ leads to cells with negligible emf-temperature coefficients such solutions are frequently used in the construction of unsaturated standard cells.

Saturated standard cells exhibit a much larger emf-temperature coefficient than unsaturated stand. are cells owing to the change in solubility of $\mathrm{CdSO}_{4}$. $8 / 3 \mathrm{H}_{2} \mathrm{O}$ with temperature. They exhibit a maximum emf at 3 to $4^{\circ} \mathrm{C}$, the temperature range of the minimum solubility of $\mathrm{CdSO}_{4} \cdot 8 / 3 \mathrm{H}_{2} \mathrm{O}$ (see table 6). Two formulas relating the emf to temperature have been proposed. Wolff [32] working with $12 \frac{1}{2}$ percent amalgams obtained:

$E_{t}=E_{20^{\circ}}-0.00004060(t-20)-0.000000950(t-20)^{2}$

$$
+0.000000010(t-20)^{3}
$$

in international volts where $E_{t}$ is the emf at temperature $t$ and $E_{20^{\circ}}$ is the emf at $20^{\circ} \mathrm{C}$. This equation is known as the International 'Temperature Formula. It is valid from 12 to $40^{\circ} \mathrm{C}$ but may be used to $0{ }^{\circ} \mathrm{C}$ as long as the liquid and solid phases of the amalgam are present. Vigoureux and Watts [110] using 6 and 10 percent amalgams, to extend the temperature range, obtained:

$$
\begin{aligned}
E_{t} & =E_{20^{\circ}}-0.00003939(t-20)-0.000000903(t-20)^{2} \\
& +0.00000000660(t-20)^{3}-0.000000000150(t-20)^{4}
\end{aligned}
$$

in international volts. These two equations are also applicable in absolute volts. This later equation is valid from -20 to $40^{\circ} \mathrm{C}$; Vigoureux and $\mathrm{W}$ atts used the 6 percent amalgam for the lower temperatures but the 10 percent amalgam gives the same results as long as the amalgam contains liquid and solid phases; thereafter the emf decreases below that given by eq (15). The cell becomes completely frozen at $-24{ }^{\circ} \mathrm{C}$; eq (15) gives $-1139.5 \mu \mathrm{V}$ for $E_{-24{ }^{\circ} \mathrm{C}}-E_{20}{ }^{\circ} \mathrm{C}$. However, when the cell becomes completely frozen the emf is approximately $1.007 \mathrm{~V}$.

The emf of "neutral" saturated standard cells, as a function of temperature, based on the above formulas, is given in figure 17. Both formulas reproduce the maximum in emf at $3{ }^{\circ} \mathrm{C}$ to $4{ }^{\circ} \mathrm{C}$, the temperature range of the minimum solubility of $\mathrm{CdSO}_{4} \cdot 8 / 3 \mathrm{H}_{2} \mathrm{O}$. Since the acidity of the electrolyte does not appreciably affect $d E / d t$, the emfs of "acid" cells would parallel the curve shown. The displacements in the curves would depend on the acidity employed (see sec. 6.2). In this figure the value at $20^{\circ} \mathrm{C}$, the temperature at which international comparisons are made, is labeled Emf standard.

The differences between eq (14) and (15) are not large. In table 13 the differences in emf at various temperatures from the emf at $20^{\circ} \mathrm{C}$ as given by these two formulas, are given. Since 10 percent amalgams are now used widely in preparing saturated standard cells eq (15) (or 18 below) should be used to calculate the change in their emf with temperature.

Above $43.6{ }^{\circ} \mathrm{C}$ where $\mathrm{CdSO}_{4} \cdot 8 / 3 \mathrm{H}_{2} \mathrm{O}$ transforms to $\mathrm{CdSO}_{4} \cdot \mathrm{H}_{2} \mathrm{O}$ the emf-temperature relation is given by [109]:

$$
E_{t}(\text { volts })=E_{43.6^{\circ}}+0.000173(t-43.6)
$$

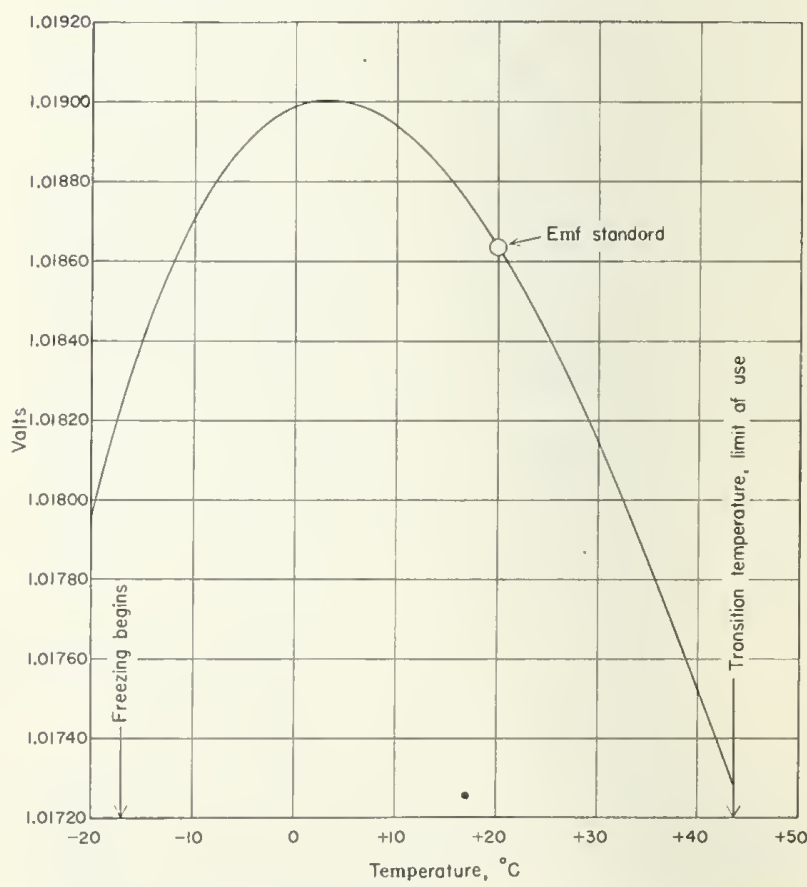

Figure 17. Relation of the electromotive force of the cadmium sulfate standard cell to the temperature. 
TABLE 13. Differences in emf of saturated standard cells from the value at $20^{\circ} \mathrm{C}$

\begin{tabular}{|c|c|c|c|c|c|}
\hline $\begin{array}{c}\text { Tempera- } \\
\text { ture }\end{array}$ & $\begin{array}{l}\text { Vigoureux and } \\
\text { Watts formula }\end{array}$ & $\begin{array}{l}\text { Inter- } \\
\text { national } \\
\text { formula }\end{array}$ & $\begin{array}{c}\text { Tempera- } \\
\text { ture }\end{array}$ & $\begin{array}{l}\text { Vigoureux and } \\
\text { Watts formula }\end{array}$ & $\begin{array}{l}\text { International } \\
\text { formula }\end{array}$ \\
\hline $\begin{array}{l}{ }^{\circ} \mathrm{C} \\
-20 \\
-19 \\
-18 \\
-17 \\
-16\end{array}$ & $\begin{array}{l}\text { microvolts } \\
-675.6^{\mathrm{a}, \mathrm{b}} \\
-575.8^{\mathrm{a}, \mathrm{b}} \\
-482.0^{\mathrm{a}, \mathrm{b}} \\
-394.2^{\mathrm{a}, \mathrm{b}} \\
-312.1^{\mathrm{b}}\end{array}$ & microvolts & $\begin{array}{l}{ }^{\circ} \mathrm{C} \\
13 \\
14 \\
15 \\
16 \\
17\end{array}$ & $\begin{array}{c}\text { microvolts } \\
229.0 \\
202.3 \\
173.5 \\
142.7 \\
109.9\end{array}$ & $\begin{array}{c}\text { microvolts } \\
234.3 \\
207.4 \\
178.1 \\
146.7 \\
113.1\end{array}$ \\
\hline $\begin{array}{l}-15 \\
-14 \\
-13 \\
-12 \\
-11\end{array}$ & $\begin{array}{r}-235.6^{\mathrm{b}} \\
-164.5^{\mathrm{b}} \\
-98.6^{\mathrm{b}} \\
-37.8^{\mathrm{b}} \\
+18.2^{\mathrm{b}}\end{array}$ & & $\begin{array}{l}18 \\
19 \\
20 \\
21 \\
22\end{array}$ & $\begin{array}{r}75.2 \\
38.5 \\
0.0 \\
-40.3 \\
-82.2\end{array}$ & $\begin{array}{r}77.4 \\
39.7 \\
0.0 \\
-41.5 \\
-84.9\end{array}$ \\
\hline $\begin{array}{l}-10 \\
-9 \\
-8 \\
-7 \\
-6\end{array}$ & $\begin{array}{l}69.3^{\mathrm{b}} \\
115.8^{\mathrm{b}} \\
157.9^{\mathrm{b}} \\
195.6^{\mathrm{b}} \\
229.2\end{array}$ & & $\begin{array}{l}23 \\
24 \\
25 \\
26 \\
27\end{array}$ & $\begin{array}{l}-126.1 \\
-171.6 \\
-218.8 \\
-267.7 \\
-318.1\end{array}$ & $\begin{array}{l}-130.1 \\
-177.0 \\
-225.5 \\
-275.7 \\
-327.4\end{array}$ \\
\hline $\begin{array}{l}-5 \\
-4 \\
-3 \\
-2 \\
-1\end{array}$ & $\begin{array}{l}258.7 \\
284.3 \\
306.0 \\
324.1 \\
338.7\end{array}$ & & $\begin{array}{l}28 \\
29 \\
30 \\
31 \\
32\end{array}$ & $\begin{array}{l}-370.2 \\
-423.9 \\
-479.2 \\
-536.1 \\
-594.6\end{array}$ & $\begin{array}{l}-380.6 \\
-435.2 \\
-491.1 \\
-548.4 \\
-606.9\end{array}$ \\
\hline $\begin{array}{r}0 \\
+1 \\
2 \\
3 \\
4\end{array}$ & $\begin{array}{l}350.0 \\
357.8 \\
362.4 \\
363.9 \\
362.4\end{array}$ & $\begin{array}{l}352.2 \\
360.0 \\
364.8 \\
366.7 \\
365.6\end{array}$ & $\begin{array}{l}33 \\
34 \\
35 \\
36 \\
37\end{array}$ & $\begin{array}{l}-654.6 \\
-716.3 \\
-779.6 \\
-844.4 \\
-911.0\end{array}$ & $\begin{array}{l}-666.6 \\
-727.4 \\
-789.3 \\
-852.1 \\
-915.9\end{array}$ \\
\hline $\begin{array}{l}5 \\
6 \\
7 \\
8 \\
9\end{array}$ & $\begin{array}{l}358.0 \\
350.8 \\
340.8 \\
328.3 \\
313.2\end{array}$ & $\begin{array}{l}361.7 \\
354.9 \\
345.4 \\
333.3 \\
318.5\end{array}$ & $\begin{array}{l}38 \\
39 \\
40 \\
41 \\
42\end{array}$ & $\begin{array}{r}-979.1 \\
-1049.0 \\
-1120.6 \\
(-1193.8) \\
(-1268.9)\end{array}$ & $\begin{array}{r}-980.6 \\
-1046.1 \\
-1112.4 \\
(-1179.3) \\
(-1246.9)\end{array}$ \\
\hline $\begin{array}{l}10 \\
11 \\
12\end{array}$ & $\begin{array}{l}295.6 \\
275.7 \\
253.5\end{array}$ & $\begin{array}{l}301.1 \\
281.3 \\
259.0\end{array}$ & $\begin{array}{l}4.3 \\
43.6\end{array}$ & $\begin{array}{l}(-1345.7) \\
(-1392.3)\end{array}$ & $\begin{array}{l}(-1315.1) \\
(-1355.8)\end{array}$ \\
\hline
\end{tabular}

- for first few hours after a change from a higher temperature; electrolyte start to freeze at $-17^{\circ} \mathrm{C}$

$\mathrm{b} \rightarrow 6$ percent amalgam.

c-values in parenthesis were obtained by extrapolation.

and unlike the cells made with $\mathrm{CdSO}_{4} \cdot 8 / 3 \mathrm{H}_{2} \mathrm{O}$ the emf-temperature coefficient is positive. The equation also applies for the metastable monohydrate down to $20{ }^{\circ} \mathrm{C}$. Vinal and Brickwedde used $43.4^{\circ}$ in eq (16) but later results [79] showed $43.6^{\circ}$ to be a better value and is used here.

Since $28{ }^{\circ} \mathrm{C}$ is frequently used as a maintenance temperature for saturated standard cells, it is convenient in such instances to have the emf-temperature relation expressed in terms of this temperature. Equations corresponding, respectively, to eq (14) and (15) but with $28{ }^{\circ} \mathrm{C}$ as the reference temperature are:

$E_{t}=E_{28^{\circ}}-0.00005390(t-28)$

$$
-0.00000071035(t-28)^{2}
$$$$
+0.000000010(t-28)^{3}
$$

and

$E_{t}=E_{28^{\circ}}-0.000052899(t-28)$

$$
\begin{aligned}
& -0.00000080265(t-28)^{2} \\
& +0.000000001813(t-28)^{3} \\
& \quad-0.0000000001497(t-28)^{4}
\end{aligned}
$$

in volts.

\begin{tabular}{|c|c|c|c|c|}
\hline \multirow{2}{*}{ Temperature } & \multicolumn{4}{|c|}{ Acidity $\left(\mathrm{H}_{2} \mathrm{SO}_{4}\right)$ of solution in cell } \\
\hline & neutral ${ }^{a}$ & $0.03 \mathrm{~N}$ & $0.05 \mathrm{~N}$ & $0.10 \mathrm{~N}$ \\
\hline${ }^{\circ} \mathrm{C}$ & volts & volt & vol & volts \\
\hline 20 & 1.018636 & 1.018612 & 1.018596 & 1.018556 \\
\hline 25 & 1.018417 & 1.018393 & 1.018377 & 1.018337 \\
\hline 28 & 1.018266 & 1.018242 & 1.018226 & 1.018186 \\
\hline 30 & 1.018157 & 1.018133 & 1.018117 & 1.018077 \\
\hline 32 & 1.018041 & 1.018017 & 1.018001 & 1.017961 \\
\hline 35 & 1.017856 & 1.017832 & 1.017816 & 1.017776 \\
\hline 37 & 1.017725 & 1.017701 & 1.017685 & 1.017645 \\
\hline
\end{tabular}

TABLE 14. Nominal emfs of saturated standard cells at some common temperatures

(Cells made with $10 \%$ cadmium amalgam)

$a_{-}$Actually $0.00092 \mathrm{~N}$; cadmium sulfate hydrolyzes to produce $\mathrm{H}_{2} \mathrm{SO}_{4}$ of this acidity at $25^{\circ} \mathrm{C}[73]$.

In table 14 the nominal values of the emf of "neutral" and "acid" saturated cells are given at a series of temperatures at which cells are most frequently calibrated at the National Bureau of Standards. Exact agreement with these nominal values cannot be expected since the emfs of saturated cells are very sensitive to the acidity of the electrolyte, to the amalgam composition, and to the extent of the solubility of the glass container in the cell electrolyte; even so they have high emf stability.

Frequently, the question arises as to the effect of small changes in temperature on the emf of saturated standard cells. Table 15 lists the changes in emf that are produced by changes in temperature of only \pm 0.001 or $\pm 0.01{ }^{\circ} \mathrm{C}$. The + sign for the emf refers to changes in emf produced by a decrease in temperature while the - sign for the emf refers to changes in emf produced by an increase in temperature. These data show that temperature must be controlled more accurately at the higher temperatures for comparable control of emf. They also show that for precisions of $0.5 \mu \mathrm{V}$ the temperature must be controlled to slightly better than $\pm 0.01{ }^{\circ} \mathrm{C}$; for $0.05 \mu \mathrm{V}$ to better than $\pm 0.001{ }^{\circ} \mathrm{C}$.

The emf-temperature formulas given above refer to the saturated cell as a whole, assuming that all parts of the cell are at the same temperature. The separate limbs of the cell have much larger coefficients, the negative limb having a negative coefficient and the positive limb a positive coefficient. The emf-temperature coefficient of the whole cell is the summation of those of the two limbs. The emf-temperature coefficients for each limb from $0^{\circ}$ to $37^{\circ} \mathrm{C}$ are given in table 16 ; those given in parenthesis were obtained by interpolation or extrapolation of the data of Sir Frank Smith [103]. The summation of those for the two limbs are given in column 4; these agree well with those calculated by International Temperature Formula. It is obvious, in view of these data, that saturated standard cells must be kept at a uniform temperature for high accuracy and precision. In table 17, are given the errors that would arise in the emf of a cell if the positive limb were at a slightly higher or slightly lower temperature than the negative limb. Also given are data for the case in which the temperature of the negative limb were slightly higher or lower temperature than the negative limb. It is for 
TABLE 15. Effect of small changes in temperature on the emf of saturated standard cells at various temperatures

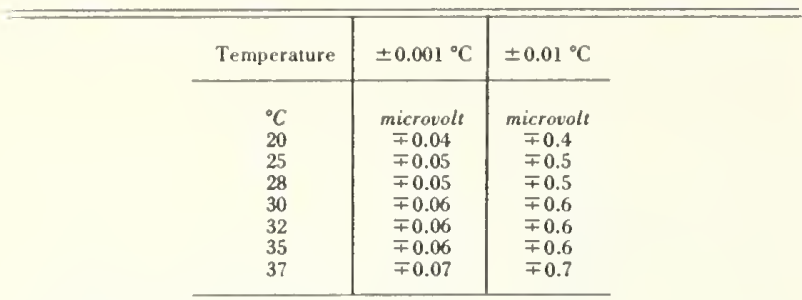

+ sign for the emf refers to a decrease in temperature.

- sign for the emf refers to an increase in temperature.

TABLE 16. Temperature coefficient of positive and negative limbs of saturated standard cells and of complete cells at various temperatures

\begin{tabular}{|c|c|c|c|c|c|}
\hline \multirow[b]{2}{*}{$\begin{array}{l}\text { Temper- } \\
\text { ature }\end{array}$} & \multirow[b]{2}{*}{ Negative limb } & \multirow[b]{2}{*}{ Positive limb } & \multicolumn{3}{|c|}{ Complete cell } \\
\hline & & & Observed & $\begin{array}{c}\text { International } \\
\text { temperature } \\
\text { formula }\end{array}$ & $\begin{array}{c}\text { Vigoureux } \\
\text { and Watts } \\
\text { formula }\end{array}$ \\
\hline $\begin{array}{r}{ }^{\circ} \mathrm{C} \\
0 \\
5 \\
10 \\
15 \\
20 \\
25 \\
28 \\
30 \\
32 \\
35 \\
37\end{array}$ & $\begin{array}{c}\text { vole/deg } \\
-0.000288 \\
-0.000297 \\
-0.000315 \\
-0.000333 \\
-0.000350 \\
-0.000366 \\
(-0.000372)^{a} \\
-0.000374 \\
(-0.000376) \\
(-0.000380) \\
(-0.000382)\end{array}$ & $\begin{array}{c}\text { vole/deg } \\
+0.000290 \\
+0.000291 \\
+0.000295 \\
+0.000302 \\
+0.000310 \\
+0.000314 \\
(+0.000314) \\
+0.000314 \\
(+0.000314) \\
(+0.000314) \\
(+0.000314)\end{array}$ & $\begin{array}{c}\text { volt/deg } \\
+0.000002 \\
-0.000006 \\
-0.000020 \\
-0.000031 \\
-0.000040 \\
-0.000052 \\
(-0.000058) \\
-0.000060 \\
(-0.000062) \\
(-0.000066) \\
(-0.000068)\end{array}$ & $\begin{array}{c}\text { volt/deg } \\
+0.000009 \\
-0.000005 \\
-0.000019 \\
-0.000031 \\
-0.000041 \\
-0.000050 \\
-0.000054 \\
-0.000057 \\
-0.000059 \\
-0.000062 \\
-0.000064\end{array}$ & $\begin{array}{l}\text { volt/deg } \\
+0.000009 \\
-0.000006 \\
-0.000019 \\
-0.000030 \\
-0.000039 \\
-0.000048 \\
-0.000053 \\
-0.000056 \\
-0.000059 \\
-0.000064 \\
-0.000067\end{array}$ \\
\hline
\end{tabular}

this reason that copper shields are used around the portable unsaturated cells (see sec. 5.4). Park [111] and Eppley [112] investigated the effect of service temperature conditions on the emf of unsaturated standard cells and Park showed that errors in emf arising from thermal inequalities could be reduced to a minimum by enclosing the cell in a copper shield.

\subsection{Emf-Temperature Hysteresis}

In general, if saturated or unsaturated standard cells are subjected to slowly changing temperatures their emf will follow closely the relations given above. If, on the other hand, the cells are subjected to abrupt temperature changes, deviations from the true emf will occur. These deviations are generally referred to as hysteresis. On cooling, the cells show first too high an emf and then a slow decrease in emf to the equilibrium value. On heating, the cells show first too low an emf and then a slow rise in emf to the equilibrium values. The magnitude of the hysteresis is given by the percentage deviation from the equilibrium value and is usually greater when the temperature is decreased than when it is increased. These general relations are illustrated in figure 18 for abrupt heating of new cells from 25 to $30{ }^{\circ} \mathrm{C}$ and for abrupt cooling from 30 to $25^{\circ} \mathrm{C}$ for unsaturated standard cells having a $\mathrm{dE} / \mathrm{dt}$ of $-5 \mu \mathrm{V} / \mathrm{deg} \mathrm{C}$ in this temperature range. The magnitude of the hysteresis in each case is given by the distance marked by an " $h$ " divided by the emf of the cell at the starting tem-
TABLE 17. Errors produced in emf of saturated standard cells if the temperature of the positive limb (or negative limb) differed from that of the negative limb (or positive limb), by small amounts, at various temperatures

\begin{tabular}{|c|c|c|c|c|c|c|c|c|}
\hline \multirow{2}{*}{$\begin{array}{l}\text { Temperature } \\
\text { difference }\end{array}$} & \multicolumn{8}{|c|}{ Temperature } \\
\hline & $0^{\circ} \mathrm{C}$ & $20^{\circ} \mathrm{C}$ & $25^{\circ} \mathrm{C}$ & $28^{\circ} \mathrm{C}$ & $30^{\circ} \mathrm{C}$ & $32{ }^{\circ} \mathrm{C}$ & $35^{\circ} \mathrm{C}$ & $37^{\circ} \mathrm{C}$ \\
\hline \multicolumn{9}{|c|}{ Positive limb } \\
\hline $\begin{array}{l}+0.01 \\
+0.005 \\
+0.001 \\
-0.001 \\
-0.005 \\
-0.01\end{array}$ & $\begin{array}{c}\mu \mathrm{V} \\
+2.9 \\
+1.5 \\
+0.3 \\
-0.3 \\
-1.5 \\
-2.9\end{array}$ & $\begin{array}{c}\mu V \\
+3.1 \\
+1.6 \\
+0.3 \\
-0.3 \\
-1.6 \\
-3.1\end{array}$ & $\begin{array}{c}\mu V \\
+3.1 \\
+1.6 \\
+0.3 \\
-0.3 \\
-1.6 \\
-3.1\end{array}$ & $\begin{array}{c}\mu V \\
+3.1 \\
+1.6 \\
+0.3 \\
-0.3 \\
-1.6 \\
-3.1\end{array}$ & $\begin{array}{c}\mu V \\
+3.1 \\
+1.6 \\
+0.3 \\
-0.3 \\
-1.6 \\
-3.1\end{array}$ & $\begin{array}{c}\mu \mathrm{V} \\
+3.1 \\
+1.6 \\
+0.3 \\
-0.3 \\
-1.6 \\
-3.1\end{array}$ & $\begin{array}{c}\mu \mathrm{V} \\
+3.1 \\
+1.6 \\
+0.3 \\
-0.3 \\
-1.6 \\
-3.1\end{array}$ & $\begin{array}{c}\mu V \\
+3.1 \\
+1.6 \\
+0.3 \\
-0.3 \\
-1.6 \\
-3.1\end{array}$ \\
\hline
\end{tabular}

\begin{tabular}{l|l|l|l|l|l|l|l|l}
\hline \multicolumn{10}{c}{ Negative limb } \\
\hline+0.01 & -2.9 & -3.5 & -3.7 & -3.7 & -3.7 & -3.8 & -3.8 & -3.8 \\
+0.005 & -1.5 & -1.8 & -1.9 & -1.9 & -1.9 & -1.9 & -1.9 & -1.9 \\
+0.001 & -0.3 & -0.4 & -0.4 & -0.4 & -0.4 & -0.4 & -0.4 & -0.4 \\
-0.001 & +0.3 & +0.4 & +0.4 & +0.4 & +0.4 & +0.4 & +0.4 & +0.4 \\
-0.005 & +1.5 & +1.8 & +1.9 & +1.9 & +1.9 & +1.9 & +1.9 & +1.9 \\
-0.01 & +2.9 & +3.5 & +3.7 & +3.7 & +3.7 & +3.8 & +3.8 & +3.8 \\
\hline
\end{tabular}

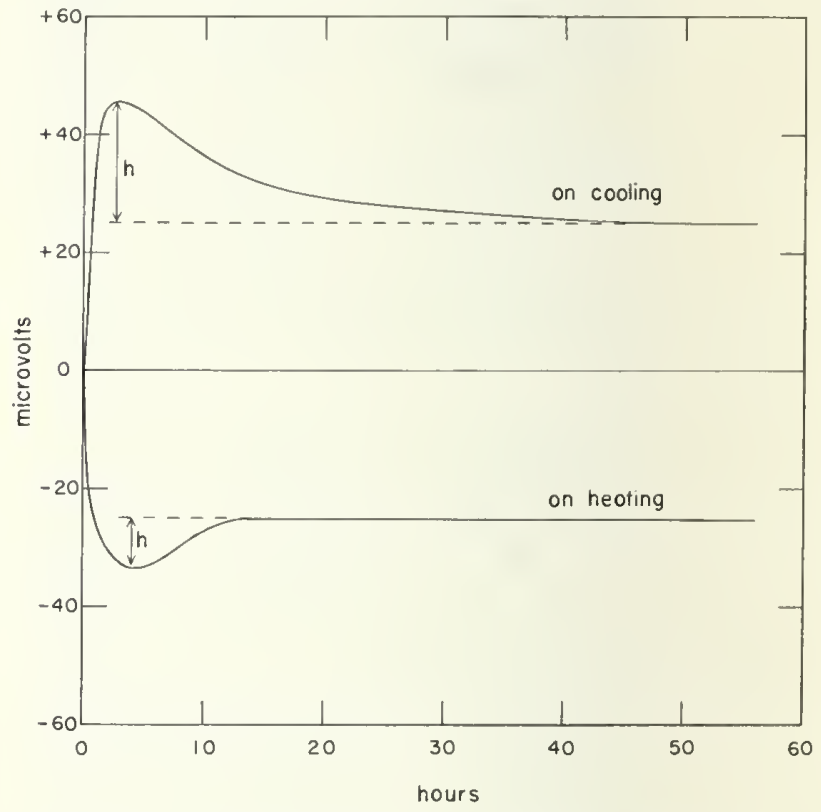

Figure 18. Relations showing the emf-temperature hysteresis of unsaturated standards when abruptly heated or cooled $5^{\circ} \mathrm{C}$.

perature (this emf may be taken as unity). This figure clearly shows that the magnitude and duration of hysteresis obtained on cooling is nearly double that found on heating; in either case the magnitude of the hysteresis is less than 0.01 percent.

For unsaturated cells the magnitude and duration of hysteresis depend on the type of construction, age, acidity and concentration of the electrolyte, on the purity of the materials, and on the rate and magnitude of the temperature change. To these must be added the size and change of solubility with temperature of the crystals of $\mathrm{CdSO}_{4} \cdot 8 / 3 \mathrm{H}_{2} \mathrm{O}$ for the saturated cell. Therefore, it is not possible to give quantitative data that may be applied as 
corrections to the emf of cells under diversified conditions involving abrupt temperature changes. Furthermore, the magnitude of hysteresis for unsaturated cells increases with age; a cell 10 years old exhibits about 10 times the hysteresis of a new cell. In general, for a $5{ }^{\circ} \mathrm{C}$ abrupt change in temperature the hysteresis of new unsaturated cells ranges from 0.01 to 0.02 percent $(0.0001$ to $0.0002 \mathrm{~V})$ on cooling and from 0.005 to 0.01 percent $(0.00005$ to 0.0001 V) on heating. The cells usually recover their original emf within 1 to 2 days after cooling and within 10 to 12 hours after heating. For older cells, hysteresis may persist for days or even months. Proportionate hysteresis is to be expected for larger or smaller temperature intervals than 5 ${ }^{\circ} \mathrm{C}$. In general, saturated cells show less hysteresis than unsaturated ones. In some cases, saturated standard cells do not exhibit the "overshoot" typical of hysteresis. Instead they approach steady emfs at a new temperature at an exceedingly slow rate. This phenomenon here called "lag" is sometimes referred to as "negative hysteresis" and is attributed to the slowness in the precipitation of $\mathrm{CdSO}_{4} \cdot 8 / 3 \mathrm{H}_{2} \mathrm{O}$ on cooling or to the slowness of dissolution of $\mathrm{CdSO}_{4} \cdot 8 / 3 \mathrm{H}_{2} \mathrm{O}$ on heating.

Many explanations have been given for hysteresis but no single factor is alone responsible. The difference between the heat capacities of the two limbs of the cell, changes in solubility of $\mathrm{CdSO}_{4} \cdot 8 / 3$ $\mathrm{H}_{2} \mathrm{O}$ (for the saturated cell) with temperature, septa (in the unsaturated cell), and the disturbances of equilibrium conditions within the cell during temperature changes must all contribute to hysteresis. In any case standard cells should be maintained at constant temperature if at all possible. Temperature fluctuations may be kept at a minimum for portable unsaturated cells by placing them in temperature-lagged boxes or in Dewar flasks. A view of a temperature-lagged box used at the National Bureau of Standards in the testing of unsaturated cells is shown in figure 19.

\subsection{Temperature Range}

The range of temperature over which standard cells may be used is dictated by the composition of the amalgam, the transition temperature of the cadmium sulfate hydrates, and the freezing point of the electrolyte. The range over which amalgams of various cadmium contents may be safely used was shown above in figure 16 . For $12 \frac{1}{2}$ percent amalgams this range is 12 to $62^{\circ} \mathrm{C}$; for 10 percent amalgams it is -8 to $51{ }^{\circ} \mathrm{C}$. Both of these amalgams may be used for a short time ( 2 to $3 \mathrm{hr}$ ) below these temperatures $\left(12 \frac{1 / 2}{2}\right.$ percent amalgam to $0^{\circ} \mathrm{C}$; 10 percent amalgam to $-20^{\circ} \mathrm{C}$ ) or as long as the amalgams consist of two phases, solid and liquid. However, for work of the highest precision the cells should be confined to the temperature ranges shown in figure 16.

A 6 percent amalgam should be chosen for lower temperatures; its useful range is -24 to $28^{\circ} \mathrm{C}$. For high temperatures amalgams of high cadmium con-

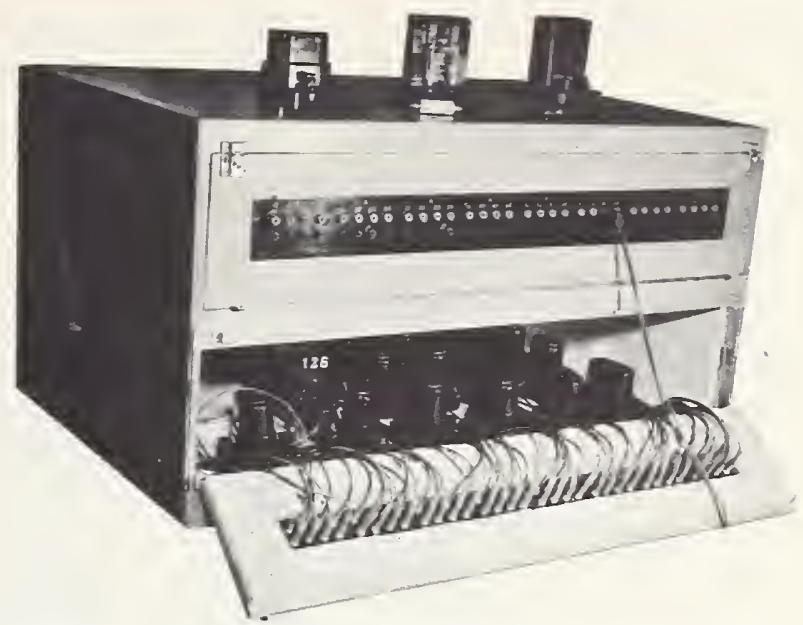

FIGURE 19. Temperature-lagged box used at the National Bureau of Standards in the testing of unsaturated standard cells.

tent should be used, viz, a 14 percent amalgam will give cells that could be used, from 24 to $67^{\circ} \mathrm{C}$. It may be possible to use unsaturated standard cells to temperatures of the boiling point of the electrolyte (slightly above $100{ }^{\circ} \mathrm{C}$ ) by using amalgams of high cadmium content (above 20 percent) but these cells would not be suitable for precision work much below $80^{\circ} \mathrm{C}$.

At temperatures above $43.6^{\circ} \mathrm{C}$, even though the higher-percentage amalgams are satisfactory, saturated cells must be made with crystals of $\mathrm{CdSO}_{4}$. $\mathrm{H}_{2} \mathrm{O}$ since this is the stable form of solid cadmium sulfate above $43.6^{\circ} \mathrm{C}$. For unsaturated standard cells no such problem exists and attention need be given only to the composition of the amalgam.

The lower limit of use is $-24{ }^{\circ} \mathrm{C}$ where the cell becomes completely frozen. Freezing begins at $-17^{\circ} \mathrm{C}$. Cells completely frozen at $-24^{\circ} \mathrm{C}$ will behave normally after thawing if freezing has not caused a fracture in the cell. The time required for the cell to recover its normal emf may be long, however. The internal resistance of standard cells at $-10^{\circ} \mathrm{C}$ is about 6 times that at $25^{\circ} \mathrm{C}$ and this increase in internal resistance may limit the use of the cell.

Significant temperatures in the use of standard cells are summarized in table 18 . In practice, cells should probably be subjected to a somewhat lesser range of temperatures than shown; -16 to $40^{\circ} \mathrm{C}$ is a good range for saturated cells and 4 to $40^{\circ} \mathrm{C}$ for unsaturated ones.

\subsection{Emf-Pressure Coefficient}

The effect of pressure on the emf of a galvanic cell at constant temperature is given by

$$
\left(\frac{d E}{d P}\right)_{T}=\frac{-(\Delta V) k}{n F} \text { volt } \text { atm }^{-1}
$$

where $\Delta V$ is the volume change in cubic centimeters at atmospheric pressure per faraday, $n$ is 


\begin{tabular}{|c|c|c|}
\hline \multicolumn{2}{|c|}{ Temperature } & \multirow{2}{*}{ Remarks } \\
\hline${ }^{\circ} \mathrm{C}$ & ${ }^{\circ} \mathrm{F}$ & \\
\hline 67 & 1526 & Upper limit for 14 percent amalgam, unsaturated cell \\
\hline 62 & 143.6 & Upper limit for $12^{1 / 2}$ percent amalgam, unsaturated cell \\
\hline 51 & 123.8 & Upper limit for 10 percent amalgam, unsaturated cell \\
\hline 43.6 & 110.5 & Transition temperature for $\mathrm{CdSO}_{4} \cdot 8 / 3 \mathrm{H}_{2} \mathrm{O}=\mathrm{CdSO}_{4} \cdot \mathrm{H}_{2} \mathrm{O}$ \\
\hline 40 & 104 & Upper practical limit recommended for standard cells \\
\hline $28-37$ & $82.4-98.6$ & Suitable range for thermostated air boxes \\
\hline 28 & 82.4 & $\begin{array}{l}\text { Temperature at which primary standard of United States } \\
\text { is maintained; also upper limit for } 6 \text { percent amalgam }\end{array}$ \\
\hline 24 & 75.2 & Lower limit for 14 percent amalgam \\
\hline 20 & 68 & $\begin{array}{l}\text { Weston Normal Cell has a nominal emf of } 1.0186360 \text { abso- } \\
\text { lute volts }\end{array}$ \\
\hline 12.1 & 53.8 & Lower limit for $12 \frac{1}{2}$ percent amalgam \\
\hline 4 & 39.2 & Lower practical limit for unsaturated cells \\
\hline $3-4$ & $37.4-39.2$ & $\begin{array}{l}\text { Emf of Weston Normal Cell is at a maximum; solubility } \\
\text { of } \mathrm{CdSO}_{4} \cdot 8 / 3 \mathrm{H}_{2} \mathrm{O} \text { is a minimum }\end{array}$ \\
\hline-8 & 17.6 & Lower limit for 10 percent amalgam \\
\hline-17 & 1.4 & Freezing begins \\
\hline-24 & -11.2 & $\begin{array}{l}\text { Cell completely frozen; will recover normal emf in about } \\
\text { a week after thawing, if not cracked }\end{array}$ \\
\hline
\end{tabular}

the number of equivalents involved in the reaction, $F$ is the faraday, and $k$ is a conversion factor, 0.101325 , which converts cubic centimeter-atmospheres into joules, i.e., volt coulombs. The volume change may be calculated from the atomic or molecular weights and the densities of the reactants and products of the reaction; for saturated standard cells this reaction is given by eq (7). At $20{ }^{\circ} \mathrm{C}$, the accepted densities of $\mathrm{Cd}, \mathrm{Hg}_{2} \mathrm{SO}_{4}$, $\mathrm{CdSO}_{4} \cdot 8 / 3 \mathrm{H}_{2} \mathrm{O}, \mathrm{Hg}$, and a saturated solution of $\mathrm{CdSO}_{4}$ are, respectively, 8.648, 7.56, and $3.090 \mathrm{~g}$ $\mathrm{cm}^{-3}$ and 13.5463 and $1.6119 \mathrm{~g} \mathrm{ml}^{-1}$ [113]. Using these data, accepted atomic weights on the $\mathrm{C}^{12}$ scale [114] and 96,487 coulombs/gram-equivalent $[115]^{15}$ for the faraday equation 19 gives $6.4 \mu \mathrm{V} / \mathrm{atm}$ for $(d E / d P)_{T}$. This value agrees excellently with $6.1 \mu \mathrm{V} / \mathrm{atm}$ found experimently by Ramsey [116] (this value is an interpolated value, Ramsey found $6.02 \mu \mathrm{V} / \mathrm{atm}$ at $20.4{ }^{\circ} \mathrm{C}$ and $7.6 \mu \mathrm{V} / \mathrm{atm}$ at $19^{\circ} \mathrm{C}$ ).

The effect of pressure on an unsaturated cell would be nearly the same, since unsaturated cells are made with solutions that are nearly saturated.

A priori no effect on the emf of sealed cells would be expected providing the pressure was insufficient to fracture the cell. Recent experiments by Catherine Law and D. N. Craig of this Bureau, in which the external pressure on the cell was increased to approximately $5 \mathrm{~atm}$, has confirmed this. Standard cells have an air space above the electrolyte which would act as a cushion to absorb pressure change even if the elasticity of the glass container were such as to transmit pressure change to the cell components.

\footnotetext{
15 In the original paper [115] values based on the physical and chemical scales of atomic weights were given. The value given here is based on an atomic weight of silver relative to the $C^{12}$ scale of atomic weights, namely, 107.870.
}

\subsection{Internal Resistance}

The internal resistance in the vicinity of $25^{\circ} \mathrm{C}$ ranges from 100 to $500 \Omega$ for unsaturated cells and from 500 to $1000 \Omega$ for saturated cells manufactured in the United States. The internal resistance increases at the rate of about 2 percent for a decrease in temperature of one degree $C$; this fact should be taken into account in calculating the $I R$ drop in a cell (see table 19). The resistances of the positive and negative limbs of symmetrical $\mathrm{H}$-shaped cells are approximately equal. As a cell ages its internal resistance increases slightly. The internal resistance of a standard cell may be estimated by momentarily placing a $10-\mathrm{M} \Omega$ resistor across the cell terminals and reading the emf, $E_{R}$. The value of the internal resistance is then given by

$$
R=10^{7}\left(E_{0}-E_{R}\right) / E_{R} \text { ohms, }
$$

where $E_{0}$ is the open-circuit emf. The cell recovers its initial emf within a few minutes after the $10-\mathrm{M} \Omega$ resistor is removed. If a cell exhibits high internal resistance or insensitivity it may contain a gas bubble at the anode which may be frequently removed by tapping the cell when inclined $45^{\circ}$. If this treatment is ineffective a new cell is recommended.

\subsection{Effect of Current}

Standard cells are not intended to serve as sources of electric current. Even so, the question frequently arises about the effect of current on standard cells, especially the unsaturated type. When standard cells are charged or discharged the 
TABLE 19. Effect of current on the emf of unsaturated standard cells at $25^{\circ} \mathrm{C}$

\begin{tabular}{c|c|c}
\hline \multirow{2}{*}{$\begin{array}{c}\text { Current, } \\
\text { ampere }\end{array}$} & \multicolumn{2}{|c}{ Internal resistance (initial change) } \\
\cline { 2 - 3 } & 100 ohms & 500 ohms \\
\hline & $\mu V$ & $\mu V$ \\
$10^{-10}$ & 0.01 & 0.05 \\
$10^{-9}$ & 0.1 & 0.5 \\
$10^{-8}$ & 1.0 & 5.0 \\
$10^{-7}$ & 10.0 & 50.0 \\
$10^{-6}$ & 100.0 & 500.0 \\
$10^{-5}$ & 1000.0 & 5000.0 \\
\hline
\end{tabular}

Changes owing to changes in amalgam $\left(V_{a}\right)$ and electrolyte $\left(V_{e}\right)$ composition (after one year)

\begin{tabular}{|c|c|c|c|c|}
\hline & $V_{a}$ & $V_{e}$ & $V_{a}$ & $V_{e}$ \\
\hline & $\mu V$ & $\mu V$ & $\mu V$ & $\mu V$ \\
\hline $10^{-10}$ & $\ldots a^{a}$ & $=-$ & $\ldots$ & $\rightarrow$ \\
\hline $10^{-9}$ & -- & -- & $-\infty$ & --- \\
\hline $10^{-8}$ & - & $\ldots$ & -- & 0.03 \\
\hline $10^{-7}$ & $\ldots$ & 0.05 & - & 0.26 \\
\hline $10^{-6}$ & & 0.5 & 0.02 & 2.6 \\
\hline $10^{-5}$ & 0.05 & 5.3 & 0.17 & 26.3 \\
\hline
\end{tabular}

\begin{tabular}{l|c|c}
\hline \multicolumn{3}{c}{$\begin{array}{c}\text { Changes arising from electrode po- } \\
\text { larization (after one year) }\end{array}$} \\
\hline & $\mu V$ & $\mu V$ \\
$10^{-10}$ & 0.1 & 0.3 \\
$10^{-9}$ & 0.7 & 2.0 \\
$10^{-8}$ & 4.3 & 12.5 \\
$10^{-7}$ & 26. & 76. \\
$10^{-8}$ & 159. & 466. \\
$10^{-5}$ & 970. & 2844. \\
\hline
\end{tabular}

a - dash means that the change is less than $0.01 \mu \mathrm{V}$

rise or drop in emf is initially dictated by the $I R$ drop and subsequently by a voltage change, $V_{c}$, associated with the chemical changes in the cell, and by electrode polarization and changes in internal resistance. For the unsaturated cell $V_{c}$ is made up of two parts: $V_{a}$, the change in emf associated with the change in the composition of the amalgam during charge or discharge and $V_{e}$, the change in emf associated with the change in electrolyte content of the solution during charge or discharge. When unsaturated cells have been discharged until their solutions are saturated the latter no longer applies. For saturated cell, $V_{c}$ consists of $V_{a}$ only.

The magnitude of $V_{a}$ obtained on discharge at $25{ }^{\circ} \mathrm{C}$ is given by

$$
V_{a}(\text { in volts })=\frac{-0.001067 I t}{F W}=-1.106 \times 10^{-8} \frac{I t}{W}
$$

where $I$ is the current in amperes, $t$ is time in seconds, $W$ is the total weight of the amalgam in grams, and $F$ is the faraday ( 96487.0 coulombs). For NBS saturated cells the total weight of amalgam is generally about $10 \mathrm{~g}$. In this case eq $(21)$ reduces to

$$
V_{a}(\text { in volts })=-1.106 \times 10^{-9} I t .
$$

For unsaturated cells having internal resistances of 100 and $500 \Omega$ the weight of the amalgam is approximately 67 and $20 \mathrm{~g}$, respectively.
The magnitude of $V_{e}$ obtained on discharge at $25{ }^{\circ} \mathrm{C}$ is given by

$$
V_{e}(\text { in volts })=\frac{-0.161 I t}{F W}=-1.67 \times 10^{-6} \frac{I t}{W}
$$

where $W$ is now the weight of the electrolytic solution in grams and the other symbols have the meaning given above. For unsaturated cells the weight of solution is about 100 and $20 \mathrm{~g}$, respectively, for cells having internal resistances of 100 and $500 \Omega$. Equation (23) then becomes

$$
V_{e}(\text { in volts })=-1.67 \times 10^{-8} I t
$$

for the $100-\Omega$ cell and

$$
V_{e}(\text { in volts })=-8.35 \times 10^{-8} \mathrm{It}
$$

for the $500-\Omega$ cell.

The magnitudes of electrode polarization ${ }^{16}$ during discharge may be calculated, within a few microvolts, by the equation

$$
\log \Delta E(\text { in microvolts })=1.6048+0.786 \log \left(\frac{C}{A}\right)
$$

where $\Delta E$ is the change in emf, in microvolts, arising from electrode polarization and changes in internal resistance, $C$ is quantity of electricity in coulombs (ampere seconds) and $A$ is apparent (geometric) electrode area in square centimeters [117]. For unsaturated cells having internal resistances of 100 and $500 \Omega, A$ is about $5.5 \mathrm{~cm}^{2}$ and $1.4 \mathrm{~cm}^{2}$, respectively. Some miniature types having internal resistances of about $1000 \Omega$ and apparent surface areas of less than $1 \mathrm{~cm}^{2}$ are also available. The length of time standard cells will sustain a discharge depends on the amount of material in the cells; most unsaturated cells of United States manufacture contain sufficient material to yield from 700 to 5000 coulombs if the current is kept below about $2 \times 10^{-5} \mathrm{~A}$ per $\mathrm{cm}^{2}$ of electrode area.

When an external load is removed, the cells recover their initial emf, provided the discharge has not been a prolonged one. The time required for recovery depends on the severity of the discharge. For example, if an unsaturated cell (internal resistance $\cong 100 \Omega$ ) is discharged for $5 \mathrm{~min}$ at $6 \times 10^{-6}$ A $\mathrm{cm}^{-2}$ it will recover its original emf within $5 \mu \mathrm{V}$ in $30 \mathrm{~min}$ and will completely recover after $6 \mathrm{hr}$. At a higher current density of $6 \times 10^{-4} \mathrm{~A} \mathrm{~cm}^{-2}$ the emf will be about $180 \mu \mathrm{V}$ below its original value after $30 \mathrm{~min}, 5 \mu \mathrm{V}$ after $6 \mathrm{hr}$, and several days will be required for complete recovery. If the cell were discharged at a current density of $6 \times 10^{-4} \mathrm{~A}$ $\mathrm{cm}^{-2}$ to a low cutoff voltage of $0.001 \mathrm{~V}$, recovery will be exceedingly slow requiring several months and

16 Includes any change in internal resistance that may occur as a cell is discharged. 
full recovery will not be attained after this prolonged period because the normal emf will have declined (see below). The time of recovery, therefore, is seen to depend on the rate and extent of the discharge.

In table 19 changes in emf caused by various currents of low magnitude are illustrated for cells hav. ing electrode cross-sectional areas of $5.5 \mathrm{~cm}^{2}$ and $1.4 \mathrm{~cm}^{2}$ and internal resistances of 100 and $500 \Omega$. The changes arising from internal resistance are initial changes whereas those arising from changes in amalgam composition, $V_{a}$, electrolyte composition, $V_{e}$, and electrode polarization (see footnote 16), $\Delta E$, are functions of time of discharge (for illustration, a period of 1 year is chosen for these). The total changes in emf during a discharge is the sum of the four effects. On a current density basis it should be noted the changes for the $100-\Omega$ and 500 $\Omega$ cells are nearly identical since the electrode area for the former cell is approximately five times that of the latter.

Standard cells may be short-circuited momentarily without permanent damage to the cells. The cells will recover their original emf within a few minutes after taken off short circuit. If kept on short circuit they will be completely discharged within $1 / 2$ to 2 days depending on the size and internal resistance of the cell, and will not recover their initial emf. The short circuit current is given by the ratio of the open-circuit emf and the internal resistance of the cell. For cells having internal resistances of $100 \Omega$ and $500 \Omega$, the short-circuit (flash) current will, therefore, be $1 \times 10^{-2}$ and $2 \times 10^{-3} \mathrm{~A}$, respectively.

\subsection{Effect of Light}

Mercurous sulfate is sensitive to light and changes in color at a slow rate through tan, to gray-brown, to dark brown, and finally to black. Although standard cells having discolored mercurous sulfate may have normal emfs [118] they exhibit slower approach to equilibrium values after temperature or other changes. Standard cells should, therefore, be mounted in nontransparent cases or kept in the dark and used only for short periods at a time under diffuse light.

\subsection{Effect of Shock}

Mechanical shocks insufficient to fracture or break or scramble the components of unsaturated standard cells have no lasting effects on the cells. Unsaturated standard cells packaged in excelsior and shipped by common carrier to the National Bureau of Standards have been observed to perform satisfactorily. When subjected to shocks of 10 to $40 \mathrm{~g}$ for durations of 6 to $18 \mathrm{msec}$ unsaturated cells exhibit large transient changes in emf ranging from 4,200 to $31,000 \mu \mathrm{V}$ [119]. After the shock the cells immediately recover their original emf within $2 \mu \mathrm{V}$. The transient emfs observed during shock probably arise from a disturbance of the mercury and amalgam surfaces during the period of shock.

On the other hand, the usual types of saturated cells of United States manufacture should not be subjected to sudden shock, should not be shipped by common carrier, should be transferred by messenger, and should not be tilted more than $45^{\circ}$. Some new saturated standard cells of novel design are stated to be portable, i.e., may be shipped by common carrier. However, studies over a period of time will be required to ascertain the long-term stability of their emf.

\subsection{Effect of Vibration}

Vibrations at frequencies from 10 to 1,000 $\mathrm{Hz}(\mathrm{c} / \mathrm{s})$ with accelerations of 1 to $10 \mathrm{~g}$ have no lasting effects on the emf of unsaturated standard cells [119]. During the vibration, however, rather large a-c voltages of the same frequency are generated. For an unsaturated cell having an internal resistance of $500 \Omega$ this a-c voltage ranges from about $25 \mu \mathrm{V}$ at $1 \mathrm{~g}$ and $1000 \mathrm{~Hz}$ to $9900 \mu \mathrm{V}$ at $10 \mathrm{~g}$ and $50 \mathrm{~Hz}$. Furthermore, there is a decrease in the d.c emf ranging from $3 \mu \mathrm{V}$ at $1 \mathrm{~g}$ and $1000 \mathrm{~Hz}$ to about $200 \mu \mathrm{V}$ at $10 \mathrm{~g}$ and $100 \mathrm{~Hz}$. In general at frequencies above $100 \mathrm{~Hz}$ the waveform of the a-c voltage is sinusoidal whereas below $100 \mathrm{~Hz}$ it is nonsinusoidal owing to the resonance of the various components of the cell. In most cases the a-c and d-c effects of the vibration appear and disappear instantaneously when vibration is started or stopped. In some instances the d.c change may be rapid in the initial moments of vibration and then build up slightly in an exponential manner for 2 or $3 \mathrm{~min}$. In these instances when the vibration is stopped the d-c emf decays in the same fashion as it was built up.

\section{Life of Standard Cells}

Saturated standard cells have an exceedingly long life. Some cells at the National Bureau of Standards have been in use for nearly 60 years, and they have retained their emfs within a few microvolts; see section 2.3. On the other hand, unsaturated cells at room temperature (about $25^{\circ} \mathrm{C}$ ) decrease in emf at a rate of about 20 to $40 \mu \mathrm{V}$ per year [48]. This decrease in emf is equivalent to a corrosion rate for the amalgam of about $(6.8$ to 13.6$) \times 10^{-7} \mathrm{~A}$ $\mathrm{cm}^{-2}$. Since the emf of new unsaturated standard cells generally range from 1.01900 to $1.01940 \mathrm{~V}$, depending on the concentration and acidity of the electrolyte, these cells on the average reach an emf of $1.01830 \mathrm{~V}$ within 23 to 37 years, providing they are maintained at $25{ }^{\circ} \mathrm{C}$ or thereabouts, and are not subjected to abuse, such as discharging or charging current; a practical life time for these cells is probably 12 to 18 years. When unsaturated standard cells reach an emf of $1.01830 \mathrm{~V}$ or lower the cells generally behave erratically (largely because the electrolyte may become supersaturated on cooling), have large emf-temperature coefficients, and show excessive emf-temperature hysteresis. The life of the cell is considerably reduced 
if the cell is stored at higher temperatures. The rate of decrease in emf is approximately doubled for every $12{ }^{\circ} \mathrm{C}$ increase in temperature [120]; thus at $37^{\circ} \mathrm{C}$ the life of an unsaturated cell would be one half that given above. Cells of the miniature type with short diffusion path between electrodes will have a shorter life.
Earlier unsaturated standard cells decreased in emf at room temperature at a rate of 70 to $85 \mu \mathrm{V}$ per year $[121,122,123]$ and, therefore, had an average theoretical life of 10 to 15 years or a practical life of 8 to 12 years. The improvement in life noted in modern cells has resulted mainly, if not entirely, from the use of improved septa in the cells.

\section{References}

[1] Giovanni Giorgi, Unità razionali di electtromagnetisimo, Atti dell' Assoc. Elettr. Ital. 5, 402 (1901); Proposal concerning electrical and physical units, Trans. Intern. Electrical Congr. 1, 136 (St. Louis, Mo., 1904).

[2] Wilhelm (E.) Weber, Messungen galvanische Leitungswiderstände nach einem absoluten Maasse, Ann. Physik. (Pogg. Ann.) 2, 82, 337 (1851); see also ref. [4].

[3] Reports of the Comm. on Electrical Standards of the Brit. Assoc. Adv. of Science (reprinted by Cambridge Univ. Press., 1913), Second Report, p. 60, Newcastle-on-Tyne, 1863.

[4] J. C. Maxwell, A treatise on electricity and magnetism, 3d ed., Vol. 2, Ch. 10, p. 263, Clarendon Press (Oxford, 1892).

[5] Ref. [3], First Report, p. 9, Cambridge, 1862.

[6] Report of the 43d meeting of the British Association for the Advancement of Science, Bradford, First report of the Committee for the Selection and Nomenclature of Dynamical and Electrical Units, Brit. Assoc. Report, p. 222,1873 .

[7] Oliver Heaviside, The relations between magnetic force and electric current.-I., The Electrician (London) 10, 6 (1882).

[8] F. B. Silsbee, Establishment and maintenance of the electrical units, NBS Cir. 475 (1949); Systems of electrical units, NBS Mono. 56, (1962); J. Res. NBS 66C. (Eng. \& Instr.), 137 (1962).

[9] C. F. Gauss, "Intensitas vis magneticae terrestris ad mensuram absolutam revocata," read before Royal Society of Göttingen on December 15, 1832, Commentationes Societatis regiae Scientarum Gottingensis recentiores, VIII, pp. 3-44 (1832-1837), Göttingen, 1841 reprinted in Carl Friedrich Gauss Werke, V, pp. 79-118, (Göttingen, 1867; 2nd printing, Göttingen, 1877), German translation in Poggendorff's Ann. Physik., XXVIII, 241-273, 591-615 (1833); second German translation by E. Dorn, Ostwald's Klassiker der exakten Wissenschaften No. 53, Leipzig, 1894.

[10] Sir William Thomson (Lord Kelvin), On the mechanical theory of electrolysis, Phil. Mag. (4) 2, 429 (1851); Practical electricity by W. E. Ayrton and T. Mather, p. 205, Cassell and Co., Ltd., London (1911): Brit. Assoc. reports on electrical standards, p. 137, Cambridge Univ. Press, 1911.

[11] A. E. Kennelly, Historical outline of the electrical units, J. Eng. Education 19, 229 (1928) reviews these developments.

[12] Sir William Thomson (Lord Kelvin), Papers on electrostatics and magnetism, Macmillan and Co., Ltd., London, p. 246,1884

[13] J. W. Trischka, U.S. Patent No. 2,959,683, Electric resonance voltage standards, Nov. 8, 1960; for theory see C. H. Townes and A. L. Schawlow, Microwave spectroscopy, Ch. 10, McGraw-Hill Book Co., Inc., New York, 1955.

[14] Y. Beers and G. L. Strine, The measurement of voltage by the use of the Stark effect, IRE Trans. Instrumentation I-II, Nos. 3 and 4, 171 (1962).

[15] F. Wenner, A proposed modification of the Kirchhoff method for the absolute measurement of resistance, by title only, Science 29, 475 (1909); see ref. [16] for details.

[16] J. L. Thomas, C. Peterson, I. L. Cooter, and F. K. Kotter, An absolute measurement of resistance by the Wenner method, J. Res. NBS 43, 291 (1949) RP2029.

[17] H. L. Curtis, C. Moon, and C. M. Sparks, A determination of the absolute ohm using an improved self-inductor, J. Res. NBS 21, 375 (1938) RP1137.

[18] R. D. Cutkoskv, Evaluation of the NBS unit of resistance based on a computable capacitor, J. Res. NBS 65A (Phys. and Chem.) 147 (1961).

[19] R. L. Driscoll and R. D. Cutkosky, Measurement of current with the National Bureau of Standards current balance, J. Res. NBS 60, 297 (1958) RP2846; R. W. Curtis, R. L. Driscoll, and C. L. Critchfield, An absolute determination of the ampere, using helical and spiral coils, J. Res. NBS 22, 485 (1939) RP1200; see also H. L. Curtis, Electrical measurements, Ch. XIX, McGraw-Hill Book Co., Inc., New York, 1937.

[20] R. L. Driscoll, Measurement of current with a Pellat-type electrodynamometer, J. Res. NBS 60, 287 (1958) RP2845.

[21] P. L. Bender and R. L. Driscoll, A free precession determination of the proton gyromagnetic ratio, IRE Trans. Instr. I-7, Nos. 3 and 4, 176 (1958).

[22] J. L. Thomas, Precision resistors and their measurement NBS Circ. 470 (1948).

[23] Latimer Clark, On a voltaic standard of electromotive force, Proc. Royal Soc. (London) 20, 444 (1872); On a standard voltaic battery, Phil. Trans. Royal Soc. I, 164, 1 (1874).

[24] Lord Rayleigh and Mrs. H. Sidgwick, On the electrochemical equivalent of silver, and on the absolute electromotive force of Clark cells, Phil. Trans. II, 175, 411 (1884).

[25] H. S. Carhart, Relation between the electromotive force of a Daniell cell with the strength of the zinc sulfate solution, Am. J. Sci. (3) 28, 374 (1884); Ref. [3], nineteenth report, Ediniburgh, 1892.

[26] K. Kahle, Beiträge zur Kenntniss der elektromotorischen Kraft des Clark'schen Normalelementes, Z. Instrumentenkunde 12, 117 (1892).

[27] R. T. Glazebrook and S. Skinner, On the Clark cell as a standard of electromotive force, Proc. Royal Soc. (London) 51, 60 (1892).

[28] H. S. Carhart, The various determinations of the e.m.f. of the Clark cell, Phys. Rev. 12, No. 3, 129 (1900).

[29] Lord Rayleigh, On the Clark cell as a standard of electromotive force, Phil. Trans. II, 176, 781 (1885).

[30] Edward Weston, Normalelement, German Patent 75,194 (Jan. 5, 1892); Improvements in voltaic cells, Britisb Patent 22,482 (Feb. 6, 1892); Voltaic cell, U.S. Patent 494,827 (Apr. 4, 1893).

[31] Report of International Conference on electrical units and standards, Oct. 12, 1908; given as Appendix 2 in ref. [8].

[32] F. A. Wolff, The temperature formula of the Weston standard cell, Bull. BS 5, 309(1908); data were submitted in October 1908 to the London International Conference on electrical units and standards.

[33] Announcement of a change in the value of the International Volt, NBS Circ. 29, p. 9, footnote 1, Dec. 31, 1910; records of NBS carried results of emf of saturated standard cells to 6 decimals from 1911 until 1934 and to 7 decimals since then.

[34] G. W. Vinal, International comparison of electrical standards, BS J. Res. 8, 729 (1932) RP448.

[35] Announcement of changes in electrical and photometric units, NBS Circ. $459,1947$.

[36] L. H. Brickwedde and G. W. Vinal, Electromotive force of saturated Weston standard cells containing deuterium oxide, J. Res. NBS 20, 599 (1938) RP1094; Relation of electromotive force to the concentration of deuterium 
oxide in saturated standard cells, J. Res. NBS 27, 479 (1941) RP1435.

[37] E. B. Rosa, G. W. Vinal, and A. S. MeDaniel, The silver voltameter-Part IV, Third series of quantitative expcriments and special investigations, BS Bull. 10, 475 (1914), Table 3 (experiments inade from 1910 to 1912 , inclusive)

[38] P. Vigoureux, International determination of the electromotive force of the Normal Weston Cell in International Volts, Coll. Res. Nat. Phys. Lab. 24, 79 (1932).

[39] H. von Steinwehr and A. Schulze, Neubestimmung der EMK des Internationalen Westonelements, Z. Instrumenk. 52, 249 (1932).

[40] H. L. Curtis and R. W. Curtis, An absolute determination of the ampere, BS J. Res. 12, 665 (1934) RP685.

[41] E. B. Rosa, N. E. Dorsey, and J. M. Miller, A determination of the International Ampere in absolute measure. BS Bull. 8, 269 (1911).

[42] W. J. Hamer, L. H. Brickwedde, and P. R. Robb, Standard cells and the unit of electromotive force, NBS Circ. 524, Electrochemical constants, Ch. 12, 1953; results obtained since 1953 extend and modify the data given in fig. 12.2 of this ref.

[43] M. Gouy, Sur une étuve à température constante, J. Physique (3) 6, 479 (1897)

[44] F. A. Wolff and C. E. Waters, Clark and Weston standard cells, BS Bull. 4, 1 (1907).

[45] P. H. Lowrie, Jr., Controlled temperature oil baths for saturated standard cells, NBS Tech. Note 141, 1962.

[46] H. B. Brooks, The standard-cell comparator, a specialized potentiometer, BS J. Res. 11, 211 (1933) RP586.

[47] J. H. Miller, A simplified standard cell comparator, AIEE Communications and Electronics, No. 14, 413 (Sept. 1954).

[48] G. D. Vincent, The construction and characteristics of standard cells, IRE Trans. Instr. I-7, Nos. 3 and 4 , 221 (1958).

[49] A. W. Spinks and F. L. Hermach, Portable potentiometer and thermostatted container for standard cells, Rev. Sci. Instr. 26, No. 8, 770 (1955).

[50] Barbara A. Wickoff, The establishment and maintenance of the unit of voltage at the National Bureau of Standards-Boulder, ISA Preprint No. 28.2.63, 18th Annual Conference and Exhibit, Chicago, Sept., 1963.

[51] A. C. Kolossov, Determination by the method of the silver voltameter of the electromotive force of the International Weston Normal Cell, Procès Verbaux, Comité international des Poids et Mesures 16, 150 (1933) Annexe No. 19.

[52] Appendix 3 of ref. [8] and p. 16 of ref. [8].

[53] Procès Verbaux, Comité International des Poids et Mesures 1 7, 94 (Resolution 4), 1935.

[54] J. F. Daniell, On voltaic combinations, Phil. Mag. III, 8, $421(1836)$

[55] W. R. Cooper, Primary batteries: their theory, construction and use, 2 d ed., Ch. IX, D. Van Nostrand Com. Ltd., London, 1916.

[56] G. W. Vinal, Primary batteries, pp. 32, 232, 233, John Wiley \& Sons, New York, 1950.

[57] Normal-Daniell-Element der Edison and Swan United Electric Light Company (Fleming and W. Thomson), Dingler's polytechnisches J. 258, 319 (1885); also Reports of Paris International Electrical Congress, 1882.

[58] W. De la Rue and H. W. Müller, On a new form of constant battery, J. Chem. Soc. 21, 488 (1868); Experimental researches on the electric discharge with the chloride of silver battery, Phil. Trans. Royal Soc. I, 169,55 (1878); this second paper deals with the cell as a standard and compares the cell with a Clark standard cell.

[59] H. Helmholtz, Die thermodynamik chemischer Vorgänge, Sitzungsber. der Königlich Preussischen Akad. der wissenschaften zu Berlin, p. 27, 1882; see also ref. [75], p. 11,74; W. Ostwald, Das kompensations-elektrometer, Z. phys. Chem. 1, 403, 1887.

[60] M. Gouy, Sur une pile étalon, Compt. Rendu. 104, 781 (1887), J. de phys. (2) 7, 532 (1888); UUber ein Normalelement, Z. physik. Chem. 2, 978 (1888).
[61] Edward Weston, Galvanic battery, U.S. Patent 310,004 (Dec. 30, 1884).

[62] H. S. Carhart, An improved standard Clark cell with low temperature coefficient, Phil. Mag. 28, 420 (1889), Am. J. Sci. (3) 38, 402 (1889); Relation between the electromotive force of a Clark cell and the density of the zinc sulphate solutions, (Proc.) Am. lnd. Elect. Eng. 9, 615 (1892).

[63] J. N. Brönsted, Studien zur chemischen affinität. V. Die bildung des kaliumbleisulfats, Z. physik. Chem. 77, 315 (1911).

[64] W. E. Henderson and G. Stegeman, A lead standard cell and a determination of the potential of the lead electrode, J. Am. Chem. Soc. 40, 84 (1918).

[65] W. C. Vosburgh, M. Guagenty, and W. J. Clayton, Saturated standard cells with small temperature coefficients. II, J. Am. Chem. Soc. 59, 1256 (1937).

[66] W. C. Vosburgh and R. G. Bates, Constancy of modified Weston standard cell over long periods, J. Electrochem. Soc. 111, 997 (1964).

[67] H. L. Callendar and H. T. Barnes, On the variation of the electromotive force of different forms of the Clark standard cell with temperature and strength of solution, Proc. Royal Soc. (London) 62, 117 (1897).

[68] G. A. Hulett, The constancy of standard cells and a constant temperature bath, Phys. Rev. 32, 257 (1911); The construction of standard cells and a constant temperature bath, The Electrician 67, 129 (1911), see also ref. [91].

[69] C. R. A. Wright and C. Thompson, On the determination of chemical affinity in terms of electromotive force. Part VII. On the electromotive force of Clark's mercurous-sulphate cell; on the work done during electrolysis. On the e.m.f. of Clark's cell, Phil. Mag. V, 16, 25 (1883).

[70] K. Kahle, Instructions for preparing Clark standard cells, The Electrician 31, 265 (1893).

[71] Ref. [55], p. 336.

[72] International Critical Tables, Vol. 2, p. 436, 1927.

[73] W. J. Hamer, Hydrolysis of aqueous solutions of cadmium and zinc sulfates at $25^{\circ} \mathrm{C}$, unpublished, NBS

[74] K. Kahle, Zur behandlung des silvervoltameters und seine verwendung zur bestimmung von Normalelement en, Ann Physik. (or Wied. Ann.) (3) 67, 1 (1899), Z. Instrk. 18 , 230 (1898).

[75] W. Jaeger, Die Normalelement und ihre anwendung in der elektrischen messtechnick, Wilhelm Knapp, Halle a.S., 1902.

[76] G. A. Hulett, Equilibria in standard cells, Phys. Rev. 27, 337 (1908).

[77] G. A. Hulett, Die destillation von amalgamen und die reinigung des quecksilbers, Z. physik. Chem. 33, 611 (1900); see also G. A. Hulett and H. D. Minchin, Distillation of amalgams and purification of mercury, Phys. Rev. 21,388 (1905).

[78] C. L. Gordon and E. Wichers, Purification of mercury and its physical properties, Ann. N.Y. Acad. Sci. 65, 369 (1957).

[79] L. H. Brickwedde, Solubility of cadmium sulfate in $\mathrm{H}_{2} \mathrm{O}-$ $\mathrm{D}_{2} \mathrm{O}$ mixtures, J. Res. NBS 36, 377 (1946) RP1707.

[80] F. Mylius and R. Funk, Über die hydrate des cadmiumsulfats, Ber. deut. chem. Ges. 30, 824 (1897).

[81] Ph. Kohnstamm and E. Cohen, Physikalisch-chemische studien am Normalelement von Weston, Ann. Physik. (or Wied. Ann.) (3) 65, 344 (1898).

[82] International Critical Tables, Vol. 1, p. 120, 1926.

[83] International Critical Tables, Vol. 2, p. 429, 1927.

[84] F. E. Smith (Sir Frank), On the preparation of a cadmium cell, The Electrician 55, 857 (1905).

[85] G. Deniges, Sur de nouvelles classes de combinaisons mercurico-organiques et sur leurs applications, Ann. chim. phys. [7] 18, 382 (specifically 397 ) 1899, see also ref. 102 .

[86] F. Laporte, Report to the International Committee on electrical units and standards, p. 111, Washington, D. C., Jan. 1, 1912.

[87] D. N. Craig, G. W. Vinal, and F. E. Vinal, Solubility of 
mercurous sulphate in sulphuric-acid solutions, J. Res. NBS 17, 709 (1936) RP939.

[88] M. Gouy, Action de l'eau sur le sulfate mercureux, Compt. rendu. 130, 1399 (1900).

[89] O. B. Hager and G. A. Hulett, The hydrolysis of mercurous sulphate, J. Phys. Chem. 36, 2095 (1932).

[90] L. H. Brickwedde, Method of making saturated cells at the National Bureau of Standards, Compt. rendu. de la Quatorzième Conference, Int. Union Pure and Applied Chem. p. 105, July 1947.

[91] G. A. Hulett, A study of the materials used in standard cells and their preparation, Part 1. Mercurous sulphate and standard cells, Trans. Am. Electrochem. Soc. 6, 109 (1904), Trans. Int. Elec. Cong., St. Louis 2, 109 (1904).

[92] F. E. Smith (Sir Frank), A dictionary of applied physics, p. 267, ed. Sir Richard Glazebrook, Macmillan and Co., Ltd., London, 1911.

[93] P. H. Walker and F. W. Smither, Comparative tests of chemical glassware, J. Ind. Eng. Chem. 9, 1090 (1917) Tech. Pap. BS 10 (1918) T107.

[94] E. Wichers, A. N. Finn, and W. S. Claybaugh, Comparative tests of chemical glassware, J. Res. NBS 26, 537 (1941) RP1394.

[95] H. Fleischer, Chemical indicator, U.S. Patent 2,416,619 (Feb. 25, 1957); Sensitive indicator for volumetric determination of boiler feedwater alkalinity, Ind. Eng. Chem., Anal. Ed. 15, 742 (1943); the author did not specifically call his indicator "methyl purple" but the indicator he suggested later became to be known by this name: see also, Water Works Manual, 1947-48 Ed.

[96] G. W. Vinal, L. H. Brickwedde, and W. J. Hamer, New quartz containers for standard cells at the National Bureau of Standards, Compt. rendu. de la Quinizième Conference, Int. Union Pure and Applied Chem., p. 92, Amsterdam, Sept. 1949.

[97] W. G. Houskeeper, The art of sealing base metals through glass, J. Am. Inst. Elec. Eng. 42, 954 (1923).

[98] C. A. Dyer, Primary electrolytic cell or group of cells (to Minneapolis-Honeywell Regulator Co.), U.S. Patent $2,647,155$ (July 28, 1953).

[99] R. O. Heinrich, Standard voltaic cell, U.S. Patent 631,044 (Aug. 15, 1899).

[100] H. Eicke and A. Kessner, Eine stabförmige Bauart des Weston-Normalelementes, Electrotech. Z. (A) 74, 623 (1953).

[101] E. F. Mueller and H. F. Stimson, A temperature-control box for saturated standard cells, J. Res. NBS 13, 699 (1933) RP739.

[102] W. C. Vosburgh and M. Eppley, The temperature coefficients of unsaturated Weston cells, J. Am. Chem. Soc. 45, 2268 (1923)

[103] Ref. [92], p. 268.
[104] Report of Natl. Phys. Lab., Electrician 75, 463 (1915).

[105] J. Obata, Cadmium standard cells containing acid electrolyte, Proc. Math. Phys. Soc. (Japan), (3), 2, 232 (1920).

[106] V. Ishibashi and T. Ishizaki, Further studies on acid stand. ard cells, Researches Electrotechnical Lab., No. 318, 1931.

[107] W. C. Vosburgh, Conditions affecting the reproducibility and constancy of Weston standard cells, J. Am. Chem. Soc. 47, 1255 (1925).

[108] F. E. Smith (Sir Frank), On cadmium amalgams and the Weston Normal Cell, Proc. Phys. Soc. (London) 22, 11 (1910); Phil. Mag. 19, 250 (1910); Natl. Phys. Lab. Coll. Res. 6, 137 (1910).

[109] G. W. Vinal and L. H. Brickwedde, Metastability of cadmium sulfate and its effect on electromotive force of saturated standard cells, J. Res. NBS 26, 455 (1941) RPl389.

[110] P. Vigoureux and S. Watts, Temperature coefficient of Weston cells, Proc. Phys. Soc. (London) 45, 172 (1933).

[111] J. H. Park, Effect of service temperature conditions on the electromotive force of unsaturated portable standard cells, BS J. Res. 10,89(1933) RP518.

[112] M. Eppley, International standard of electromotive force and its low-temperature-coefficient form, Trans. AIEE 50, No. 41923 (1931).

[113] International Critical Tables, Vol. 1, $\mathrm{CdSO}_{4} \cdot 8 / 3 \quad \mathrm{H}_{2} \mathrm{O}$ (p. 120), $\mathrm{Hg}_{2} \mathrm{SO}_{4}$ (p. 121); $\mathrm{Vol}$. 2, Cd (p. 456), $\mathrm{Hg}$ (p. 458); Vol. 3, sat. sol. $\mathrm{CdSO}_{4}$, interpolated (p. 66).

[114] Table of atomic weights, 1961 (Based on carbon-12), Chem. and Eng. News., p. 43, Nov. 20, 1961.

[115] D. N. Craig, J. I. Hoffman, C. A. Law, and W. J. Hamer, Determination of the value of the faraday with a silverperchloric acid coulometer, J. Res. NBS 64A (Phys. and Chem.) 381 (1960).

[116] R. R. Ramsey, The change of volume in Clark and cadmium cells and its relation to change of electromotive force due to pressure, Phys. Rev. XVI, No. 2, 105 (1902).

[117] Based on measurements made at Natl. Bur. Standards by Phyllis R. Robb and W. J. Hamer, 1950-52; see also ref. [120].

[118] G. A. Hulett, Mercurous sulphate and the standard cell, Phys. Rev. 22, 321 (specially 336, footnote 1) 1906.

[119] R. J. Brodd and W. G. Eicke, Jr., Effect of vibration and shock on unsaturated standard cells, J. Res. NBS 66C (Eng. and Instr.) 85 (1962).

[120] G. D. Vincent, Effect of current drains on cadmium standard cells, J. Electrochem. Soc. 104, 712 (1957).

[121] G. W. Vinal, D. N. Craig, and L. H. Brickwedde, Standards of electromotive force, Trans. Electrochem. Soc. 68, 139 (1935).

[122] Ref. [56], p. 211.

[123] F. X. Lamb. Aging of standard cells, NBS Circ. 524, Electrochemical constants, Ch. 11, 1953.

\section{Appendix 1}

\section{U.S. Law of 1894, 53d Congress, 28 Stat., Ch. 131, p. 102 (Public-No. 105)}

An Act To define and establish the units of electrical measure

Be it enacted by the Senate and House of Representatives of the United States of America in Congress assembled, That from and after the passage of this Act the legal units of electrical measure in the United States shall be as follows:

First. The unit of resistance shall be what is known as the international ohm, which is substantially equal to one thousand million units of resistance of the centimeter-gram-second system of electro-magnetic units, and is represented by the resistance offered to an unvarying electric current by a column of mercury at the temperature of melting ice fourteen and four thousand five hundred and twenty-one ten-thousandths grams in mass, of a constant cross-sectional area, and of the length of one hundred and six and three tenths centimeters.

Second. The unit of current shall be what is known as the international ampere, which is onetenth of the unit of current of the centimeter-gramsecond system of electro-magnetic units, and is the practical equivalent of the unvarying current, which, when passed through a solution of nitrate of silver in water in accordance with standard specifications, deposits silver at the rate of one thousand one hundred and eighteen millionths of a gram per second.

Third. The unit of electro-motive force shall be what is known as the international volt, which is the electro-motive force that, steadily applied to a 
conductor whose resistance is one international $\mathrm{ohm}$, will produce a current of an international ampere, and is practically equivalent to one thousand fourteen hundred and thirty-fourths of the electro-motive force between the poles or electrodes of the voltaic cell known as Clark's cell, at a temperature of fifteen degrees centigrade, and prepared in the manner described in the standard specifications.

Fourth. The unit of quantity shall be what is known as the international coulomb, which is the quantity of electricity transferred by a current of one international ampere in one second.

Fifth. The unit of capacity shall be what is known as the international farad, which is the capacity of a condenser charged to a potential of one international volt by one international coulomb of electricity.

Sixth. The unit of work shall be the Joule, which is equal to ten million units of work in the centimeter-gram-second system, and which is prac- tically equivalent to the energy expended in one second by an international ampere in an international ohm.

Seventh. The unit of power shall be the $W$ att, which is equal to ten million units of power in the centimeter-gram-second system, and which is practically equivalent to the work done at the rate of one Joule per second.

Eighth. The unit of induction shall be the Henry, which is the induction in a circuit when the electromotive force induced in this circuit is one international volt while the inducing current varies at the rate of one Ampere per second.

Sec. 2. That it shall be the duty of the National Academy of Sciences to prescribe and publish, as soon as possible after the passage of this Act, such specifications of details as shall be necessary for the practical application of the definitions of the ampere and volt hereinbefore given, and such specifications shall be the standard specifications herein mentioned.

\section{Appendix 2 \\ Public Law 617-81st Congress \\ (Chapter 484-2d Session)}

(S. 441)

AN ACT

To redefine the units and establish the standards of electrical and photometric measurements.

Be it enacted by the Senate and House of Representatives of the United States of America in Congress assembled, That from and after the date this Act is approved, the legal units of electrical and photometric measurements in the United States of America shall be those defined and established as provided in the following sections.

SEC. 2. The unit of electrical resistance shall be the ohm, which is equal to one thousand million units of resistance of the centimeter-gram-second system of electromagnetic units.

SEC. 3. The unit of electric current shall be the ampere, which is one-tenth of the unit of current of the centimeter-gram-second system of electromagnetic units.

SEC. 4. The unit of electromotive force and of electric potential shall be the volt, which is the electromotive force that, steadily applied to a conductor whose resistance is one ohm, will produce a current of one ampere.

SEC. 5. The unit of electric quantity shall be the coulomb, which is the quantity of electricity transferred by a current of one ampere in one second.

SEC. 6. The unit of electrical capacitance shall be the farad, which is the capacitance of a capacitor that is charged to a potential of one volt by one coulomb of electricity.

SEC. 7. The unit of electrical inductance shall be the henry, which is the inductance in a circuit such that an electromotive force of one volt is induced in the circuit by variation of an inducing current at the rate of one ampere per second.

SEC. 8. The unit of power shall be the watt, which is equal to ten million units of power in the centimeter-gram-second system, and which is the power required to cause an unvarying current of one ampere to flow between points differing in potential by one volt.

SEC. 9. The units of energy shall be (a) the joule, which is equivalent to the energy supplied by a power of one watt operating for one second, and (b) the kilowatt-hour, which is equivalent to the energy supplied by a power of one thousand watts operating for one hour.

SEC. 10. The unit of intensity of light shall be the candle, which is one-sixtieth of the intensity of one square centimeter of a perfect radiator, known as a "black body", when operated at the temperature of freezing platinum.

SEC. 11. The unit of flux of light shall be the lumen, which is the flux in a unit of solid angle from a source of which the intensity is one candle.

SEC. 12. It shall be the duty of the Secretary of Commerce to establish the values of the primary electric and photometric units in absolute measure, and the legal values for these units shall be those represented by, or derived from, national reference standards maintained by the Department of Commerce.

SEC. 13. The Act of July 12, 1894 (Public Law Numbered 105, Fifty-third Congress), entitled "An Act to define and establish the units of electrical measure", is hereby repealed.

APPROVED July 21, 1950. 


\section{Appendix 3}

\section{Standard Cells with Deuterium Oxide}

The electromotive forces of saturated standard cells, made with deuterium oxide and normal water follow:
Percentage of $\mathrm{D}_{2} \mathrm{O}$ in the water $0.02^{a}$

10
20
30
40
50
60
70
80
90
100 (extrapolated from

98 percent)
Emf at $20{ }^{\circ} \mathrm{C},{ }^{b}$ volts 1.018603

1.018567

1.018531

1.018495

1.018459

1.018423

1.018384

1.018344

1.018301

1.018255

1.018204 a - Normal water contains 0.02 percent deuterium oxide

- Original data were reported in international volts and have here been converted to absolute volts.

These cells were made with crystals of cadmium sulfate in equilibrium with the respective solutions. This was accomplished by saturating each solution with anhydrous cadmium sulfate; the crystals that separated from the solution were then in equilibrium with the saturated solution. The solutions were then made 0.035 to $0.042 N$ with respect to sulfuric acid; the above emfs are reported on a uniform basis of $0.04 \mathrm{~N}$.

Cadmium sulfate is about 8 percent less soluble in heavy water than in normal water in the temperature range of 0 to $60^{\circ} \mathrm{C}$. This comparison follows:

\begin{tabular}{cc|c|c}
\hline \multirow{2}{*}{$\begin{array}{c}\text { Temperature } \\
{ }^{\circ} \mathrm{C}\end{array}$} & \multicolumn{2}{c}{ Moles CdSO ${ }_{4}$ per mole water } \\
\cline { 3 - 4 } & & normal water ${ }^{b}$ & heavy water \\
& 0 & 0.06546 & 0.06026 \\
& 5 & .06555 & .06033 \\
& 10 & .06566 & .06042 \\
$\mathrm{CdSO}_{4} \cdot 8 / 3 \mathrm{aq}^{a}$ & 15 & .06580 & .06055 \\
& 20 & .06600 & .06073 \\
& 25 & .06627 & .06097 \\
& 30 & .06663 & .06130 \\
& 35 & .06710 & .06174 \\
& 40 & .06773 & .06232 \\
& 45 & .06857 & .06311 \\
& 50 & .06955 & .06415 \\
& 45 & .06797 & .06326 \\
& 50 & .06659 & .06181 \\
$\mathrm{CdSO}_{4} \cdot \mathrm{aq}^{a}$ & 55 & .06522 & .06037 \\
& 60 & .06385 & .05893 \\
& & \\
\hline
\end{tabular}

${ }^{a}$ - here aq means either $\mathrm{H}_{2} \mathrm{O}$ or $\mathrm{D}_{2} \mathrm{O}$

${ }^{b}$ - contains 0.02 percent heavy water.

Studies of the changes in the difference between the emf of cells made with normal and heavy water with time have given supplemental evidence on the stability of the National Reference Group of Standard Cells. These studies have shown that this difference is within the spread, namely, $0.05 \mu \mathrm{V} /$ year, discussed under item (1) on maintenance in section 2.3. However, cells made with heavy water have not, to date, shown the same internal consistency as those made with normal water, i.e., individual cells show greater day-to-day variations in emf than normal water cells.

\section{Appendix 4}

Coulometer (Smith form) measurements* by the United States in the Physikalisch-Technische Reichsanstalt at Charlottenburg, 1931

\begin{tabular}{|c|c|c|c|c|c|c|c|c|c|c|}
\hline \multirow{2}{*}{ ltem } & \multicolumn{10}{|c|}{ Experiment Number** } \\
\hline & 1 & 2 & 3 & 4 & 5 & 7 & 8 & 9 & 10 & \\
\hline $\mathbf{A}$ & 4.09189 & 4.09328 & 4.09600 & 4.08556 & 4.08615 & 4.10120 & 4.09495 & 4.09105 & 4.16814 & \\
\hline B & 4.09172 & 4.09317 & 4.09591 & 4.08543 & 4.08621 & 4.10123 & 4.09507 & 4.09110 & 4.16824 & \\
\hline C & 7230.00 & 7199.85 & 7200.06 & 7199.84 & 7200.01 & 7200.16 & 7200.06 & 7199.84 & 7320.05 & \\
\hline D & 1.999989 & 1.999973 & 1.999973 & 1.999975 & 1.999973 & 1.999971 & 1.999975 & 1.999981 & 1.999985 & \\
\hline E & 0.000005 & 0.000005 & 0.000005 & 0.000005 & 0.000005 & 0.000005 & 0.000005 & 0.000005 & 0.000005 & \\
\hline$F$ & 1.018301 & 1.018429 & 1.018411 & 1.018336 & 1.018334 & 1.018331 & 1.018328 & 1.018332 & 1.018334 & \\
\hline G & 1.018301 & 1.018430 & 1.018402 & 1.018336 & 1.018334 & 1.018330 & 1.018328 & 1.018330 & 1.018332 & \\
\hline H & 1.012582 & 1.017114 & 1.018145 & 1.015176 & 1.015326 & 1.019020 & 1.017458 & 1.016712 & 1.018796 & \\
\hline J & 1.018259 & 1.018390 & 1.018694 & 1.018296 & 1.018293 & 1.018288 & 1.018283 & 1.018283 & 1.018286 & \\
\hline K & 0.000011 & 0.000011 & 0.000014 & 0.000014 & 0.000013 & 0.000015 & 0.000013 & 0.000013 & 0.000012 & \\
\hline L & 1.018116 & 1.018299 & 1.018234 & 1.018229 & 1.018220 & 1.018238 & 1.018266 & 1.018070 & 1.018144 & ave $=1.018202$ \\
\hline M & 1.018187 & 1.018370 & 1.018305 & 1.018300 & 1.018291 & 1.018309 & 1.018337 & 1.018141 & 1.018215 & ave $=1.018273$ \\
\hline
\end{tabular}

*Electrical measurements made in PTR units; (USA - PTR) ohm $=9 \mathrm{ppm}$; (USA - PTR) volts $=-61 \mathrm{ppm}$.

* Experiment Number 6 was conducted with a porous-cup coulometer, therefore, not included.

A-weight of silver deposit in one coulometer, grams.

$\mathrm{B}$ - weight of silver deposit in second coulometer in series with A, grams.

C-time of electrolysis, seconds.

$\mathrm{D}$-resistance $R$ of standard rcsistor, ohms.

E-correction for resistance owing to leads, etc., ohm

$\mathrm{F}$-average emf of control cell at $20^{\circ} \mathrm{C}$, volts.

$\mathrm{C}$ - emf of control cell at $20^{\circ} \mathrm{C}$ at end of run, volts.

$\mathrm{H}-I R$ in standard resistor, volts; $/$ is current in amperes.

$\mathrm{J}$-emf of German reference cell at $20^{\circ} \mathrm{C}$, volts.

$\mathrm{K}$-correction to $J$ to give mean value of Kleiner Stamm (primary volt standard of Germany), volt.

$\mathrm{L}-$ German value of selected cell at $20^{\circ} \mathrm{C}$; given by

$$
E_{s}=\left[\left(\frac{A+B}{2}\right)\left(\frac{D}{0.001118 C}\right) \frac{F J}{G H}\right]+(E+K) \text { volts }
$$

M-LSA (USA units) value of selected cell at $20^{\circ} \mathrm{C}$; given by 


\section{Appendix 5}

\section{Constant-Temperature Oil Baths}

Constant-temperature oil baths of the type used to maintain the National Reference Group of Standard Cells at a constant temperature were shown in figure 2. In this appendix a general description of a typical bath is presented. A circular bath of stainless steel or nickel-plated copper, about $75 \mathrm{~cm}$ in diameter and $45 \mathrm{~cm}$ deep, may be used (all other metal parts are also of steel or nickel-plated copper to prevent the possibility of galvanic corrosion). It is filled with oil (see Appendix 6) to a depth of about $35-40 \mathrm{~cm}$. The oil is stirred by a centrally located two-blade agitator which produces an upward and rotary circulation. The agitator (9) is about 48 $\mathrm{cm}$ in length, $5 \mathrm{~cm}$ wide, $0.3 \mathrm{~cm}$ thick, has a pitch of $20^{\circ}$ and rotates at about $45 \mathrm{rpm}$. It is supported on a shaft (1) which is supported in ball bearing housings at the bottom and top of the bath (the one at the top is supported in a metal slab (3), about 10 $\mathrm{cm}$ wide and $0.3 \mathrm{~cm}$ thick, which rests on the central top edges of the bath. A drip cup (4) is placed on the shaft at the position shown to collect any grease that may flow down the shaft from the ball bearing housing. To guide the direction of oil circulation a metal baffle (5), $25 \mathrm{~cm}$ in height, is placed in the bath in the position shown in figure Al. This baffle extends to $10 \cdot \mathrm{cm}$ of the bottom of the bath and slightly above the agitator. This baffle serves also to protect the cells from direct influence of the heating element and the cooling coils.

Heating is supplied by a heating coil (8) of bare manganin wire wound on a Pyrex rod having a diameter of $1 \mathrm{~cm}$. This rod is supported about 5 $\mathrm{cm}$ above the bottom of the bath by glass supports and circles the bath; its position is clearly shown in figure Al. The heating coil has a resistance of 90 ohms and operates on $110-\mathrm{V}$ d-c supply. A bank of four incandescent lamps in parallel is included in the heating circuit; two lamps operate intermittently during control while two operate continuously, i.e., some heating is provided continuously and some intermittently. Cooling coils (7), (11), as shown, are also provided. Through these coils flow oil of the same type as used in the bath. These coils are connected to similar coils in the freezing compartment of a refrigerator and the required cooling is attained by controlling the rate of oil flow. Cooling by this means is required only in emergencies or when tests of standard cells are made at temperatures below room temperature. The temperature of the bath is determined by a platinum resistance thermometer and a Mueller bridge; the thermometer is supported at the position (2) shown in the figure. The lamps in the circuit also aid an operator in determining when the bath has attained a peak temperature (one reading on $\mathrm{Pt}$ resistance thermometer) and a

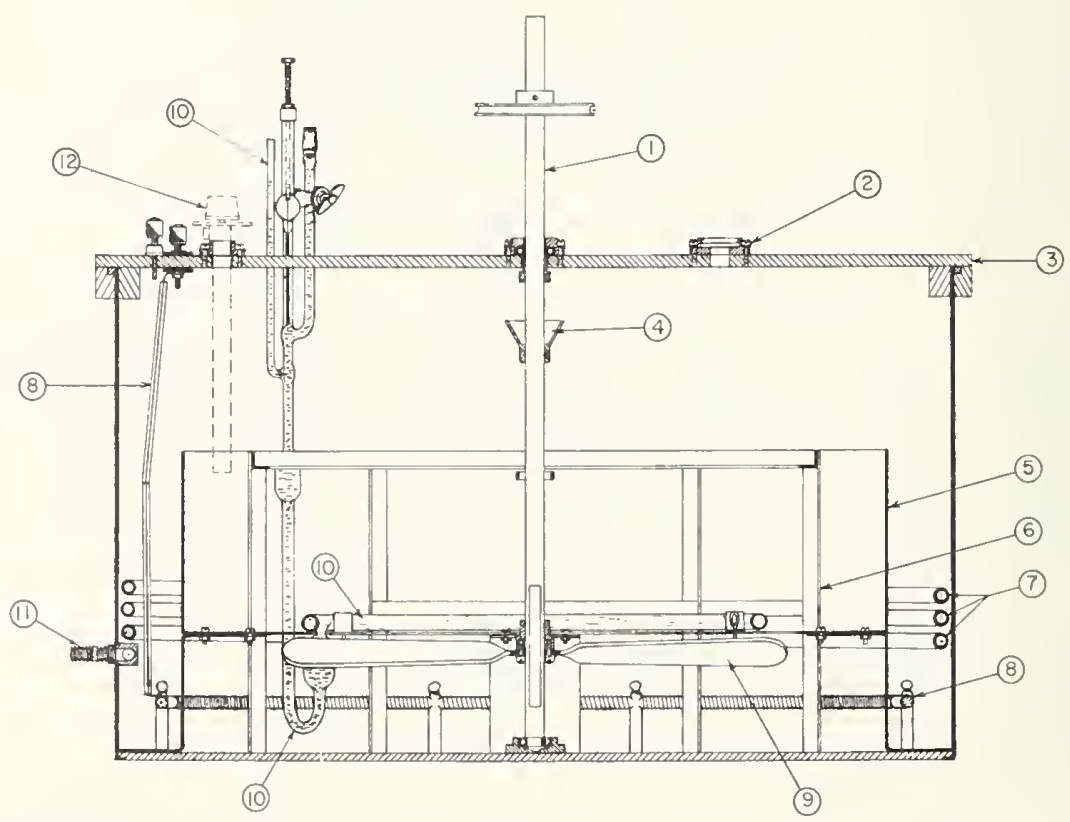

FIGURE A1. Cross-sectional sketch of a constant-temperature oil bath used at the

\begin{tabular}{lc}
\multicolumn{2}{c}{ National Bureau of Standards. } \\
1-Agitator shaft & 7-Cooling coils \\
2-Thermometer mount & 8-Heater \\
3-Center plate & 9 -Agitator \\
4-Drip cup & 10-Mercury-toluene regulator \\
5-Baffle & $11-$ Cooling coil connector \\
6-Cell rack & $12-$ Fenwall thermoswitch
\end{tabular}


lower temperature (second reading on $\mathrm{Pt}$ resistance thermometer) and thereby determine the mean temperature of the bath (the period between peak and low temperatures is about $15 \mathrm{sec}$ ).

A mercury-toluene regulator (10) is used as the temperature-control element. It consists of a reservoir in the form of a rectangle, $40 \mathrm{~cm}$ on an edge, made of thin-walled Pyrex tubing, $1.5 \mathrm{~cm}$ in diameter, containing the thermometric, substance (toluene), the volume changes being transmitted by a U-shaped connecting tube filled with mercury to a vertical capillary as shown in the figure. The U. shaped connecting tube is provided with a downward extension from the toluene reservoir to allow for expansion and contraction of the toluene thereby preventing the toluene from reaching the capillary. The capillary is about $1 \mathrm{~mm}$ in diameter and $8 \mathrm{~cm}$ long and the adjustable electrical contact to the mercury is made with a steel piano wire. The permanent electrical terminal to the mercury is made through a seal about $4 \mathrm{~cm}$ below the capillary tube. This terminal is connected to the electromagnet of a sensitive $150-\Omega$ relay, whereas the adjustable terminal is connected to one terminal of a long-life Lalande battery of 2.5 volts; the other terminal of this battery is connected to the electromagnet. The secondary of the relay is in the 110 -volt $\mathrm{d}$-c heater circuit. The regulator is supported on the baffle about $10 \mathrm{~cm}$ from the bottom of the bath. The capillary extends above the oil and is therefore, exposed to the air; this exposure, however, does not cause a significant error in regulation. A Fenwall thermoswitch (12) is included in the heating circuit as a precaution in case the regulator does not function; this thermoswitch opens the heating circuit at a preset value, usually $1{ }^{\circ} \mathrm{C}$, above the temperature at which the bath is controlled. The standard cells are mounted in the bath on the metal rack (6) in the manner described in the text (sec. 2.3). Other details on the bath are shown in figure A1.

\section{Appendix 6}

\section{Oil for Constant-Temperature Baths}

The quality of the oil in which standard cells are submerged is of considerable importance, and for this purpose a white mineral oil with the following specifications is used:

Colorless, odorless, tasteless;

Viscosity, in poises at $25^{\circ} \mathrm{C}, 0.245^{*}$;

Specific gravity, $25^{\circ} \mathrm{C}, 0.846$;

Flashpoint, $171^{\circ} \mathrm{C}\left(340{ }^{\circ} \mathrm{F}\right)$;

Burning point, $207^{\circ} \mathrm{C}\left(405^{\circ} \mathrm{F}\right)$;
Acidity (mg KOH/gm oil), none;

Sulfur, none;

Oxidation number, 0 ;

Gum, on heating in oxygen, none;

Discoloration, on heating in oxygen, slight orange. * Sufficiently low as to make the stirring effective.

In addition this oil, when new, has a resistivity of about $3 \times 10^{14} \mathrm{ohm}-\mathrm{cm}$ or higher.

\section{Appendix 7}

\section{Constant-Temperature Enclosure for Saturated Standard Cells}

The Mueller-Stimson temperature-control box for saturated standard cells was described in general terms in section 5.4. In this appendix more details are given. In this control box, the temperature of an outer aluminum case is automatically controlled by a conventional mercury-in-glass thermoregulator. A second aluminum case, inside the first and thermally well insulated from it, contains five saturated standard cells. The inner case assumes a temperature very nearly the time average of that of the outer case. The inner case is $3 \frac{5}{8} \mathrm{in}$. long, $23 / 4$ in. wide, and $4 \mathrm{in}$. deep inside. This case is a casting with $1 / 4$-in. walls and $3 / 8$ in. bottom. A $1 / 4$-in.-thick cover is secured to the casting by numerous screws to improve thermal contact. The inner case is spaced within the outer one with $1 / 2$ in. balsa wood on all six sides. The outer case is also a casting, with $3 / 8$ in. sidewalls and $1 / 2$ in. bottom. A cover of sheet $3 / 8$-in. alumi- num is secured to the top by screws. The endwalls of the casting are plane on the inside and cylindrical on the outside, the thickness at the edges being $3 / 8$ in. and $3 / 4$ in. at the middle; this extra thickness at the middle provides space for a vertical hole, $15 / 32 \mathrm{in}$. in diameter and $6 \mathrm{in}$. deep, to accommodate the thermoregulator at one end and a smaller hole to accommodate a thermometer at the other end.

The outer case is insulated with a layer of balsa wood 1 in. thick on the sides and bottom and $2 \mathrm{in}$. thick on the top. The pieces of balsa wood fit neatly into an outer wooden box. This box is of sufficient size to provide a compartment at one end to house a transformer, relay, and binding posts for the necessary connections. These accessories are mounted on a wooden panel which slides in vertical grooves in the sides of the box. The outside dimensions of the box are 8 by 13 in., by 10 in. deep, and its weight, complete, is $22 \mathrm{lb}$. A horizontal section of the control box is shown in figure A2. 


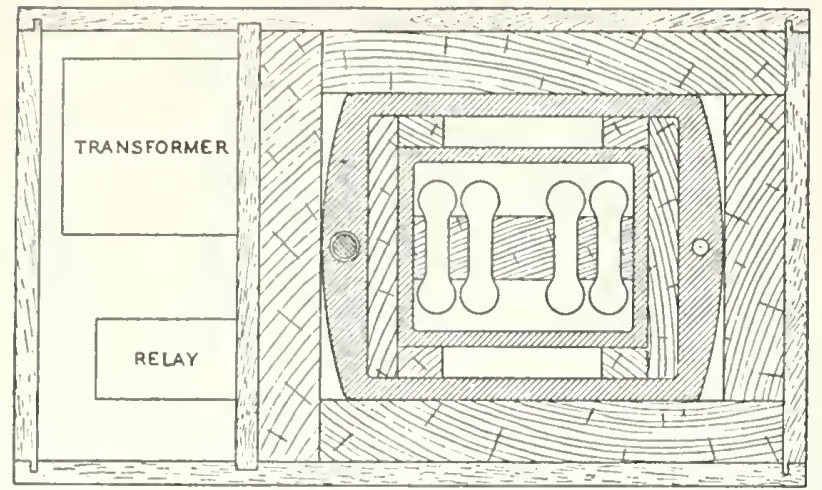

FIgURE A2. Horizontal sketch of Mueller-Stimson temperaturecontrolled box.

The standard cells are mounted on balsa wood of appropriate size. No. 28 (0.013 in.) insulated copper wire, $4 \mathrm{ft}$. in length, is used for connections to the cell terminals. About one-third of this length is formed in a helix which is kept inside the inner case and another one-third is placed between the inner and outer cases. The wires are brought through the cases in smoothed saw cuts in the upper edges of the sides and insulated additionally with silk and glyptal whereby good thermal contact with the metal cases is assured. These thermal tiedowns and lengths of wire reduce heat conduction to a negligible amount. Sheets of mica are placed on the surfaces of the aluminum cases, adjacent to the connecting wires, to protect them against accidental electrical grounding. Outside the outer case the wires are brought to binding posts supported on a hard-rubber strip; the positive terminal is placed on one side of the box, the negative on the other.

The thermoregulator is an adjustable mercury-inglass type with a bulb 4 in. long about $15 / 32$ in. in diameter, and 8 in. long. It is covered with grease to assure good thermal contact to the reservoir into which it fits.

The heating resistor, No. $38(0.004$ in.) constantan wire, has a resistance of about $70 \Omega$ and is wound in four turns on the sides and ends of the outer aluminum case on silk fabric. One turn is placed near the top edge and another near the bottom edge of the case. It operates on $20 \mathrm{~V}$. A small, quickacting $12-\mathrm{V}$ a-c relay operating on about $0.05 \mathrm{~A}$ is used. Power for the heater and relay is supplied by a bell-ringing transformer rated at $50 \mathrm{~W}$. 

U.S. DEPARTMENT OF COMMERCE

WASHINGTON, D.C. 20230

OFFICIAL BUSINESS
POSTAGE AND FEES PAID U.S. DEPARTMENT OF COMMERCE 